\title{
REVIEW
}

\section{Zooplankton fecal pellets, marine snow and sinking phytoplankton blooms}

\author{
Jefferson T. Turner* \\ School for Marine Science and Technology, University of Massachusetts Dartmouth, 706 South Rodney French Boulevard, \\ New Bedford, Massachusetts 02744-1221, USA
}

\begin{abstract}
Zooplankton fecal pellets have long been thought to be a dominant component of the sedimentary flux in marine and freshwater ecosystems, but that view is changing. The last 2 decades have seen publication of $>500$ studies using sediment traps, which reveal that zooplankton fecal pellets often constitute only a minor or variable proportion of the sedimentary flux. Substantial proportions of this flux are from organic aggregates ('marine snow') of various origins, including phytoplankton blooms, which sediment directly to the benthos. It now appears that mainly large fecal pellets of macrozooplankton and fish are involved in the sedimentary flux. Smaller fecal pellets of microzooplankton and small mesozooplankton are mostly recycled or repackaged in the water column by microbial decomposition and coprophagy, contributing more to processes in the water column than flux to the benthos. The relative contributions of fecal pellets, marine snow and sinking phytoplankton to the vertical flux and recycling of materials in the water column are highly variable, dependent upon multiple interacting factors. These include variations in productivity, biomass, size spectra and composition of communities in the overlying water columns, and trophic interactions between various components of the plankton and nekton communities at various times, locations and depths. Other factors include differences in sinking rates, sizes, composition and pollutant contents of fecal pellets produced by various sizes of zooplankters, and zooplankton feeding-fecal pellet production interactions in relation to upwelling and El Niño periods, seasonal life-history-related zooplankton vertical migrations and long-term oceanographic regime shifts. There are also suggestions from the geological record that zooplankton fecal pellets may have been important in ancient oceans. The ecological roles of marine snow and phytoplankton aggregates in sedimentary flux also depend on a variety of interacting factors, including sources of origin, degrees of microbial colonization, depth distributions, sinking rates and ingestibility by consumers. Perhaps the major reversal of the previous paradigm on the role of fecal pellets in the sedimentary flux over the last 2 decades has been the realization that much, if not most, of the organic rain from the epipelagic to the abyss is due to direct sedimentation of aggregated phytoplankton, which does not appear to undergo consumption in the water column, and which may be related to seasonality of surface production cycles. Further, there is emerging evidence for benthic responses to sedimented phytodetritus, including apparent synchrony of reproductive cycles of some deep-sea benthic animals with seasonality of sinking of surface blooms. Such episodic input of surface phytodetritus may help resolve apparent discrepancies between average supply and demand of organic matter required to maintain benthic community metabolism. The sedimentary flux of fecal pellets, marine snow and sinking phytoplankton is an important component of the biological pump that not only transports and recycles materials in the sea but also may help scrub greenhouse gases from the atmosphere.
\end{abstract}

KEY WORDS: Zooplankton fecal pellets • Marine snow · Sinking phytoplankton blooms · Sedimentary flux

Resale or republication not permitted without written consent of the publisher

\section{INTRODUCTION}

The ocean is aphotic and therefore aphotosynthetic below the upper few tens to hundreds of meters, yet there is animal and microbial life throughout, including down to the greatest depths. Except for communities around hydrothermal vents, which produce organic matter by bacterial chemosynthesis, the 
organic matter required to maintain deep-water pelagic and benthic ecosystems must ultimately derive from the photosynthetic system in the epipelagic. This has been recognized at least since Agassiz (1888) proposed that '...deep-sea organisms are nourished by a "rain" of organic detritus from overlying surface waters.' Since sedimenting organic particles are subject to a gauntlet of microbial degradation, it has long been thought that fast-sinking materials such as zooplankton fecal pellets are primary agents of the downward flux in the sea.

Turner \& Ferrante (1979) reviewed literature on transport potential, nutritional content, recycling by decomposition and coprophagy, and pollutant content of zooplankton fecal pellets in marine and freshwater ecosystems. During the intervening 2 decades, it has become apparent that zooplankton fecal pellets remain important agents of vertical flux under some circumstances, but that in other cases, most fecal pellets are reprocessed in the water column by microbial decomposition or coprophagy. Further, in many instances, most of the vertical flux is due not to fecal pellets, but to marine snow or sedimenting phytoplankton blooms that descend to the benthos without entering water-column consumer food webs. It is also apparent that the dynamics of fecal pellets, marine snow and sinking phytoplankton blooms are important not only in the flux to the benthos but also to pelagic communities throughout the water column.

Removal of carbon dioxide from the atmosphere, and its processing by the photosynthetic system in the upper ocean, with subsequent descent and sequestering in the deep sea may be important aspects of the 'biological pump' (Longhurst \& Harrison 1988) mitigating anthropogenic increases in greenhouse gases (Longhurst 1991, Sarmiento 1991). The sedimentary particulate flux from varying combinations of sinking fecal pellets, marine snow and phytoplankton is generally considered much more important than the active downward flux due to vertical migrations of zooplankton and nekton (Longhurst \& Harrison 1988, Longhurst et al. 1989, 1990, Longhurst \& Williams 1992), although there may be exceptions to this (Bradford-Grieve et al. 2001, Hays et al. 2001), and vertically migrating zooplankton may contribute substantially to the flux of dissolved organics and inorganics (Dam et al. 1995, Hays et al. 1997, Zhang \& Dam 1997, Steinberg et al. 2000, Al-Mutairi \& Landry 2001). Important reviews and analyses of vertical flux processes have appeared over the last 2 decades (Angel 1984, Smetacek 1984, Hargrave 1985, Fowler \& Knauer 1986, Alldredge \& Silver 1988, Michaels \& Silver 1988, Angel 1989, Bishop 1989, Bruland et al. 1989, Legendre \& Gosselin 1989, Longhurst \& Harrison 1989, Peinert et al. 1989, Toggweiler 1989, Wefer 1989, Banse 1990, Fowler
1991, Longhurst 1991, 2000, Noji 1991, Silver \& Gowing 1991, Wassmann 1991a, 1998, Fortier et al. 1994, Wassmann 1994, Legendre \& Le Fèvre 1995, Thingstad \& Rassoulzadegan 1995, Bathmann 1996, Kiørboe 1996, Legendre \& Rassoulzadegan 1996, Wassmann et al. 1996a,b, Butterfield 1997, Lampitt \& Antia 1997, Azam 1998, Legendre \& Michaud 1998, Falkowski et al. 2000). The present review will update and extend that of Turner \& Ferrante (1979) to present the emerging view that zooplankton fecal pellets are often less important in the sedimentary flux than marine snow and sinking phytoplankton blooms.

\section{IMPORTANCE OF ZOOPLANKTON FECAL PELLETS}

\begin{abstract}
'Indeed, this concern for bioenergetics, energy flow, and processes has been so pervasive that biological oceanography now suffers from an agricultural mentality that would have us believe that bioenergetics is the only valid subject of investigation. At times this narrow outlook has even degenerated into the peculiar belief that the waste products of an animal are somehow more important than the animal itself.'
\end{abstract}

Hamner (1985) p. 417

Much of the early evidence for the importance of fecal pellets in the sedimentary flux came from studies employing sediment traps. Turner \& Ferrante (1979) cited only the first few of the flurry of studies, beginning mainly in the mid-1970s, using sediment traps (Moore 1931, Schrader 1971, Steele \& Baird 1972, Ansell 1974, Wiebe et al. 1976, Soutar et al. 1977, Honjo 1978, Spencer et al. 1978a,b, Knauer et al. 1979) or large-volume filtration systems (Bishop et al. 1977, 1978) to quantify vertical flux in the open sea, as well as in coastal waters (Hargrave \& Taguchi 1978, Smetacek et al. 1978, Taguchi \& Hargrave 1978). Publications (>500) from most sediment-trap studies appeared after the Turner \& Ferrante (1979) review (Table 1).

Many sediment-trap studies have revealed that zooplankton fecal pellets or fecal matter are important components of rapid particulate flux in the sea. Perhaps the most dramatic evidence for this was the discovery that radionuclides from the Chernobyl disaster were present in zooplankton fecal pellets in sediment traps at $200 \mathrm{~m}$ depth in the Mediterranean an average of $7 \mathrm{~d}$ after peak radioactivity was delivered to the surface and $<2 \mathrm{wk}$ after the explosion (Fowler et al. 1987). On the basis of theoretical considerations, Jumars et al. (1989) have also concluded that the principal pathway of dissolved organic carbon from phytoplankton back to bacterioplankton (i.e., 'closing the microbial loop') is through rapid release from zooplankton fecal pellets. 
Table 1. Publications from marine studies with sediment traps, particle interceptor traps and large-volume filtration systems appearing since the review of Turner \& Ferrante (1979)

1979: Crisp et al., Hargrave \& Burns, Hinga et al., Larrance et al., Rowe \& Gardner

1980: Bishop et al., Brewer et al., Gardner a,b, Honjo, Honjo et al., Iseki et al., Tanoue \& Handa, Volkman et al., Wakeham et al.

1981: Blomqvist \& Kofoed, Chester \& Larrance, Deuser et al. a,b, Dunbar \& Berger, Dymond et al., Fellows et al., Iseki, Knauer \& Martin, Landing \& Feely, Lorenzen et al., Sasaki \& Nishizawa, Syvitski \& Murray, Takahashi \& Honjo, Thunell \& Honjo, Urrère \& Knauer

1982: Ducklow et al., Feely et al., Gagosian et al., Honjo, Honjo et al. a,b, Lee \& Cronin, Repeta \& Gagosian, Staresinic et al., Taguchi a,b, Wefer et al.

1983: Burns \& Villeneuve, De Baar et al., Deuser et al. a,b, Falkowski et al., Fowler \& Fisher, Fowler et al., Gagosian et al. a,b, Gardner et al., Gowing \& Silver, Gulliksen, Lee et al., Livingston \& Anderson, Lorenzen \& Welschmeyer, Lorenzen et al. a,b, Small et al., Staresinic et al., Wassmann

1984: Andrews et al., Betzer et al. a,b, Bishop \& Marra, Cowen \& Silver, Davies \& Payne, Dunbar, Gardner et al., Ittekkot et al., Izdar et al., Jickells et al., Karl \& Knauer a,b, Karl et al., Knauer et al., Lee \& Cronin, Murphy \& Dymond, Repeta \& Gagosian, Silver et al., Tett, Wakeham et al., Wassmann, Welschmeyer et al.

1985: Altabet \& Deuser, Bacon et al., Baker et al., Bé et al., Burns et al., Cadée, Cowen \& Bruland, Deming, Deming \& Colwell, Downs \& Lorenzen, Ducklow et al., Dymond \& Lyle, Gowing \& Silver, Noriki et al. a,b, Schnack, Wassmann, Welschmeyer \& Lorenzen

1986: Bishop \& Joyce, Bishop et al. a,b, Bodungen, Bodungen et al., Cadée, Deuser, Emerson et al., Feeley et al., Fowler et al., Harada \& Tsunogai, Kajihara et al., Knap et al., Larsson et al., Matsueda \& Handa, Müller et al., Noji et al., Noriki \& Tsunogai, Peinert, Pisias et al., Simoneit et al., Skjoldal \& Wassmann, Takahashi, Taylor et al., Tsunogai et al. a,b, Wassmann, Wassmann et al.

1987: Asper, Atkinson \& Wacasey, Bathmann et al., Benli, Bernstein et al., Bodungen et al., Broman et al., Buesseler et al., Carey, Coale \& Bruland, Deuser, Emerson \& Roff, Fowler et al., Harding et al., Heussner et al., Honjo et al., Hsiao, Izdar et al., Kempe \& Nies, Kempe et al., Liebezeit, Martin et al., Michaelis et al., Nelson et al., Peinert et al., Pilskaln \& Honjo, Richardson \& Hollister, Small et al., Smith, Smith et al., Takahashi a,b,c, Tambiev, Tanoue \& Handa, Tsunogai \& Noriki

1988: Altabet, Baker et al., Bathmann, Biscaye et al., Bodungen et al., Deuser et al., Dymond \& Collier, Emerson \& Hedges, Fischer et al., Fisher et al., Hedges et al. a,b, Heussner et al., Honjo \& Doherty, Honjo et al., Karl et al., Kempe \& Jennerjahn, Kusakabe et al., Laws et al., Lee et al., Maita et al., Moore \& Dymond, Morris et al., Naes et al., Sancetta \& Calvert, Sasaki et al., Walsh et al. a,b, Wefer et al.

1989: Altabet a,b, Bhosle et al., Costello et al., Deuser \& Ross, Faganeli, Fleeger et al., Graf, Hargrave et al., Laws et al., Longhurst et al., Lutter et al., Nair et al., Nöthig \& Bodungen, Pedros-Alio et al., Riebesell, Sancetta a,b, Small et al., Smith, Smith et al. a,b, Takahashi, Taylor, Tremblay et al., Wakeham \& Lee, Wassmann

1990: Banse, Bathmann et al., Berger \& Wefer, Bernstein et al., Buesseler et al., Coale, Deuser et al., Gadel et al., Grimalt et al., Gundersen \& Wassmann, Hay et al., Huh et al., Jahnke et al., Knauer et al., Longhurst et al., Meinecke \& Wefer, Michaels et al., Monaco et al. a,b, Montgomery et al., Novitsky, Peterson \& Dam, Reemtsma et al., Rowe et al., Sakugawa et al., Takahashi et al., Vangriesheim \& Khripounoff, Wakefield \& Smith, Wassmann a,b, Wassmann et al., Wefer et al.

1991: Abelmann \& Gersonde, Altabet et al., Bathmann et al.,
Bodungen et al., Buesseler, Fabry \& Deuser, Fowler et al., Hebbeln \& Wefer, Ittekkot et al., Karl \& Knauer, Karl et al., Knauer, Leventer, Posedel \& Faganeli, Proctor \& Fuhrman, Rutgers van der Loeff \& Berger, Sancetta et al., Sautter \& Thunell, Taylor \& Karl, Tsunogai \& Noriki, Voss, Wassmann a,b, Wassmann et al., Wefer \& Fischer

1992: Abelmann a,b, Asper et al., Ayukai \& Hattori, Bianchi et al., Bishop et al., Cadée et al., Cowen, González, Honjo et al., Lampitt, Landry et al., Lee et al., Lohrenz et al., Puàkarić et al., Rau et al., Reimers et al., Simon et al., Small \& Ellis, Smith et al., Waite et al.

1993: Bauerfeind et al., Boltovskoy et al., Gardner et al., Gowing, Haake et al., Head \& Horne, Honjo \& Manganini, Lampitt et al. a,b, Lenz et al., Lochte et al., Martin et al., Miquel et al., Noji et al., Passow \& Peinert, Passow et al., Pfannkuche \& Lochte, Reinfelder et al., Wakeham et al., Weeks et al.

1994: Anderson et al., Biscaye \& Anderson, Carlson et al., Falkowski et al., González \& Smetacek, González et al. a,b, Hargrave et al., Head et al., Karl \& Tilbrook, Kiørboe et al., Landry et al. a,b, Lane et al., Marty et al., Michaels et al. a,b, Miquel et al., Peinert \& Miquel, Rowe et al., Sayles et al., Smith et al., Thunell et al. a,b, Turley \& Mackie, Walsh, Wassmann et al.

1995: Bodungen et al., Buck \& Newton, Buesseler et al., Deuser et al., Heiskanen, Heiskanen \& Leppänen, Honjo et al., Lampitt et al., Landry et al., Luo et al., Riebesell et al., Turley \& Mackie, van der Wal et al.

1996: Andreassen et al., Bacon et al., Dymond \& Collier, Etcheber et al., Fischer et al., Jickells et al., Karl \& Lukas, Karl et al., Keck \& Wassmann, Kiørboe et al., Michaels \& Knap, Murray et al., Osinga et al., Pilskaln et al., Reigstad \& Wassmann, Rivkin et al., Smith et al., Witte

1997: Berelson et al., Christian et al., Conte, Curry \& Ostermann, Diercks \& Asper, Dortch et al., Duineveld et al., Emerson et al., François \& Bacon, Hansell et al. a,b, Honjo, Honjo \& Weller, Karl et al., Koning et al., Lampitt \& Antia, Lundsgaard \& Olesen, Rodier \& Le Borgne, Roman \& Gauzens, Thunell, Valdes et al., Wakeham et al.

1998: Andreassen \& Wassmann, Baldwin et al., Beaulieu \& Smith, Bode et al., Carroll et al., Conte et al., Druffel et al., Dunbar et al., Heiskanen et al., Lazzari et al., Lee et al., Shaw et al., Sherrell et al., Silver et al. a,b, Smith \& Druffel, Smith et al., Steinberg et al., Thunell a,b

1999: Altabet et al., Antia et al., Asper \& Smith, Beaufort \& Heussner, Bishop et al., Boyd et al., Cailliau et al., Charette et al., Danovaro et al., Druffel \& Robison, Heussner et al., Honjo et al., Noji et al. a,b, Peña et al., Pfannkuche et al., Radakovitch \& Heussner, Scharek et al., Smith \& Kaufmann, Thibault et al., Urban-Rich et al., Viitasalo et al., Wassmann et al., Wong et al., Wu et al.

2000: Alleman et al., Andruleit, Broerse et al. a,b, Collier et al., Conan \& Brummer, Danovaro et al. a,b,c, Duineveld et al., Fischer et al., Gardner et al., Giraudeau et al., Goericke et al., González et al. a,b, Gust \& Kozerski, Gyldenfeldt et al., Haidar et al., Hebbeln, Hebbeln et al., Honjo et al., Kemp et al., Kincaid et al., Lampitt et al., Loh \& Bauer, Prahl et al., Reigstad et al., Rixen et al., N. Romero et al., O. E. Romero et al., Roy et al., Sempéré et al., Stavrakakis et al., Sumida et al., Thunell et al., Waite et al., Waniek et al., Wassmann et al., Young \& Ziveri, Ziveri \& Thunell, Ziveri et al., Zonneveld \& Brummer

2001: Antia et al., Bauerfeind et al., Benitez-Nelson et al., Christiansen et al., Conte et al., Dadou et al., Gowing et al., Hamm et al., Harada et al., Harris et al., Hedges et al., Herman et al., Hernes et al., Hidaka et al., King \& Howard, McCave et al., Müller \& Fischer, Nodder \& Northcote, Nodder \& Waite, Olesen, Passow et al., Prahl et al., Romero et al., Scholten et al., Smith et al., Steinberg et al., Wollast \& Chou, Zeldis 
The relative importance of zooplankton fecal pellets in sedimentary flux and water-column recycling depends on various factors. These include fecal pellet sinking rates, chemical and particulate contents (including pollutants), fate of fecal pellets in terms of microbial decomposition or coprophagy and organisms producing (and therefore sizes of) fecal pellets, and the possible importance of zooplankton fecal pellets in oceans of the geological past. These will be reviewed before addressing the variable contribution of zooplankton fecal pellets to the sedimentary flux in the present-day ocean and the emerging view that much of the sedimentary flux in the ocean is due to marine snow and direct sedimentation of phytoplankton blooms.

\section{Fecal pellet sinking rates}

Fecal pellets sink rapidly. All published sinking rates for fecal pellets reviewed by Turner \& Ferrante (1979) were for fecal pellets of unknown origin or those produced by copepods or euphausiids. These rates ranged from $<10$ to typically hundreds of meters per day. Subsequent sinking rate data for fecal pellets of various other animals (Table 2) considerably broaden the range of sinking rates.

Fecal pellets of salps and pteropods generally sink from hundreds to thousands of meters per day, whereas less dense, more flaky pellets of doliolids (Bruland \& Silver 1981, Madin 1982, Deibel 1990) or

Table 2. Sinking rates of zooplankton fecal pellets, marine snow and phytodetritus

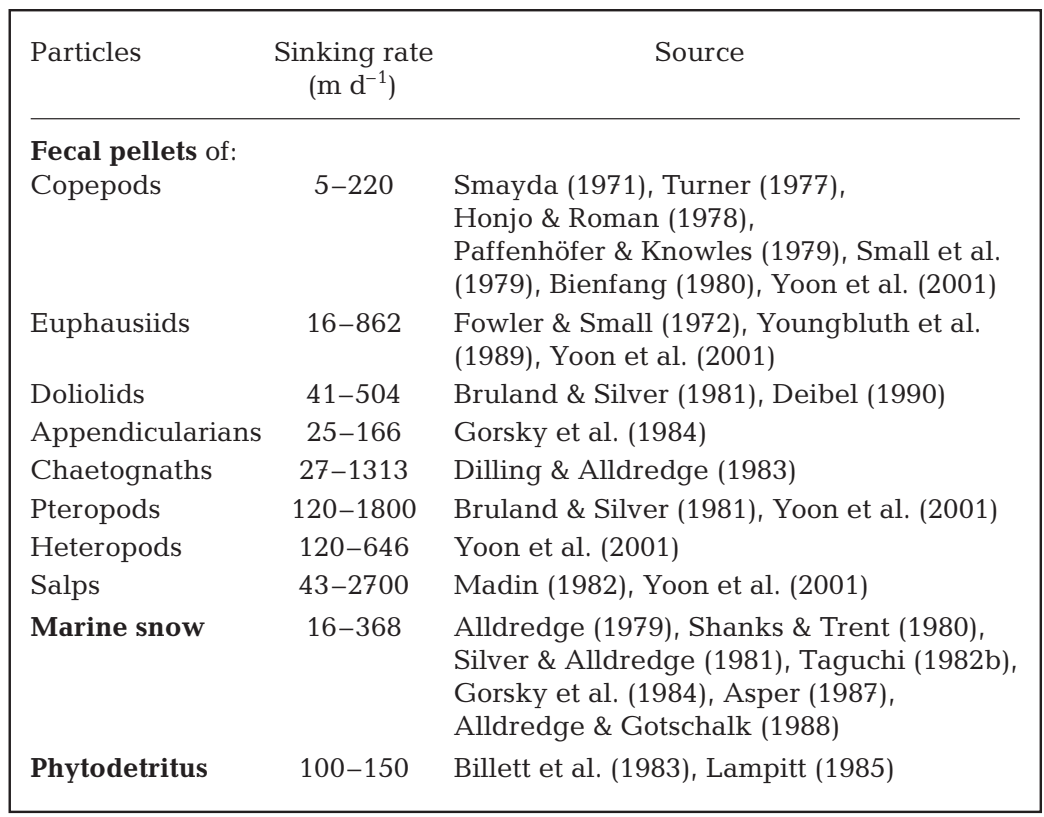

discarded houses and fecal pellets of the appendicularian Oikopleura dioica (Gorsky et al. 1984) sink only tens to hundreds of meters per day.

The high rates of sinking of fecal pellets from salps and pteropods appear related to the larger volumes of these pellets. Due to the widespread abundance of salps and pteropods in oceanic waters, the high organic content of their fecal pellets (Bruland \& Silver 1981, Madin 1982) and the rapid defecation rates of salps (Madin 1982), fecal pellets of these gelatinous zooplankters may contribute disproportionately to the vertical flux to the benthos.

A mass occurrence of salps was recorded by Wiebe et al. (1979) in the northwest Atlantic. Salpa aspera performed diel vertical migrations over distances of $800 \mathrm{~m}$, resulting in evacuation of 85 to $90 \%$ of the zooplankton biomass from the upper $500 \mathrm{~m}$ during daylight. Since salps feed upon small particles in the epipelagic, such a migration would have removed massive amounts of primary production to depth. Salp fecal pellet production and mortality during this event were estimated to contribute over $100 \%$ of the daily energy requirements of the deep-sea benthos. Other mass occurrences of salps that produced episodic fecal pellet fluxes in the benthos were recorded by Bathmann (1988), Morris et al. (1988), Pfannkuche \& Lochte (1993), and Perissinotto \& Pakhomov (1998).

Variations in consumer diets can affect sinking rates of resulting fecal pellets. Small et al. (1979) reported that natural copepod fecal pellets sank at higher and more variable rates than those produced on laboratory phytoplankton diets. This was presumably due to variations in fecal pellet contents and densities, since pellets produced from diets of cultured phytoplankton mixed with sediment sank faster than those produced on phytoplankton diets alone. Small et al. (1979) recommended against extrapolating measurements of sinking rates made on pellets produced on laboratory diets to those of fecal pellets produced on natural diets. For natural fecal pellets of both small copepods and the large copepod Anomalocera patersoni, collected under calm sea conditions, there was an increase in sinking rates with increases in fecal pellet volumes, but there was no such relation for fecal pellets collected in rough seas. Bienfang (1980) found no relationship between fecal pellet sinking rates and volumes for pellets of the copepod Calanus finmarchicus produced on 
diets of diatoms versus flagellates but found that the fecal pellets produced on the diatom diets sank significantly faster. Bienfang (1980) suggested that this difference was due to higher densities of pellets containing remains of diatom frustules. Komar et al. (1981) concluded that a modified version of the Stokes equation gave a reasonable approximation of measured rates of Small et al. (1979) for sinking rates of cylindrical fecal pellets of copepods and euphausiids, and that most variations in sinking rates of such fecal pellets were due to diet-related pellet densities. Indeed, euphausiid fecal pellets in the Antarctic were larger and sank faster when produced on diets dominated by diatoms than on non-diatom phytoplankton (Cadée et al. 1992, González 1992a). Deibel (1990) discovered that doliolid fecal pellets produced on diets of natural particulates did not sink but that pellets produced on diets of microflagellate, dinoflagellate and diatom cultures sank at rates of 59 to $405 \mathrm{~m} \mathrm{~d}^{-1}$. Dilling \& Alldredge (1993) concluded that while chaetognath fecal pellets were large (approximately 1 to $4 \mathrm{~mm}$ long), due to their contents (copepod parts) pellet density was low, and with sinking rates 5 to 10 times slower than those of comparably sized herbivores such as salps and doliolids. Urban et al. (1993a) reported that densities of fecal pellets of a larvacean and a copepod varied with season, depending on types of phytoplankton ingested and the extent to which remains were compacted in pellets. Frangoulis et al. (2001) found that sinking rates of copepod fecal pellets decreased from 100 to $70 \mathrm{~m} \mathrm{~d}^{-1}$ during the transition from diatom- to Phaeocystis-dominated spring blooms, and suggested that the lower sinking rates were due to decreases in pellet density and volume when feeding on Phaeocystis sp.

Sinking rates of copepod fecal pellets vary with pellet size, and pellet size varies with food concentration, food composition and ingestion rate. Dagg \& Walser (1986) found that pellet size increased with increasing food concentration up to chlorophyll levels of $3 \mu \mathrm{g} \mathrm{l}^{-1}$, above which size remained constant. Below this level, ingestion and defecation were balanced so that copepod guts did not fill and fecal pellet size was smaller, but above this level, copepod guts did fill, producing fecal pellets of maximum size. Dagg \& Walser (1986) concluded that fecal pellets produced by copepods under low food conditions would likely sink at lower rates than pellets produced by the same copepods at higher food levels. Ayukai \& Nishizawa (1986) also reported that pellet sizes were smaller at lower food concentrations and that the ratio of defecated volume to ingested volume was higher with a dinoflagellate than a diatom diet. Tsuda \& Nemoto (1990) found that ingestion rates, fecal pellet production rates and fecal pellet size increased with increasing food concentrations. Feinberg \& Dam (1998) reported that various characteristics (length, width, density, calculated sinking rate) of fecal pellets of the copepod Acartia tonsa were significantly different with different laboratory diets of diatoms, photosynthetic and heterotrophic flagellates, dinoflagellates and ciliates. Sinking rates of fecal pellets from other copepods vary with food conditions (Butler \& Dam 1994) and size of the fecal pellet producer (Harris 1994). Rates of sinking of salp fecal pellets can vary with the decomposition state of the pellets (Yoon et al. 1996). Dam \& Feinberg (2001) found significant relationships between fecal pellet sinking rate and weight of fecal pellet producers, and between fecal pellet sinking rate and volume.

Silver \& Bruland (1981) and Bruland \& Silver (1981) concluded that diets of salps and pteropods in the California Current differed considerably, and that this would affect the vertical chemical fluxes resulting from their fecal pellets. Salps fed mainly upon small phytoplankton, so when coccolithophorids were abundant, their fecal pellets presumably contributed to enhanced calcite flux. Pteropods in the same area fed primarily upon larger phytoplankton, especially diatoms, so their fecal pellets would be expected to facilitate enhanced silicate flux.

In an exaggerated example of the effects of ingested mineral particles on fecal pellet sinking rates, Taghon et al. (1984) and Komar \& Taghon (1985) found that fecal pellets of a deposit-feeding polychaete were large (up to $9.7 \mathrm{~mm}$ long), had high density due to ingested sediment (1.086 to $1.282 \mathrm{~g} \mathrm{~cm}^{-3}$ ) and high sinking rates (2618 to $5132 \mathrm{~m} \mathrm{~d}^{-1}$ ). Similar processes might also apply to planktonic organisms, since abundant fine-grained lithogenic particles were filtered by Oikopleura dioica (Dagg et al. 1996) and by copepods (Turner 1984a,b, 1987) in the plume of the Mississippi River.

\section{Fecal pellet contents}

Contents of fecal pellets have long been used to examine the diets of the zooplankters that produce them (Fig. 1). These analyses include studies of copepods (Turner 1977, 1978, 1984a,b,c, 1985, 1986a,b, 1987, 1991, Turner \& Anderson 1983, Bathmann et al. 1990a,b, Voss 1991, Urban et al. 1992, 1993b, González et al. 1994a,b), euphausiids grazing on epontic (underice) algae (O'Brien 1987, González et al. 1994a) and protists (Buck \& Newton 1995).

Levels of photosynthetic pigments and phaeopigments, and other chemicals such as carbon, nitrogen, phosphorus and radiolabeled compounds in fecal pellets have also been used to examine patterns of zooplankton feeding and fecal pellet decomposition 


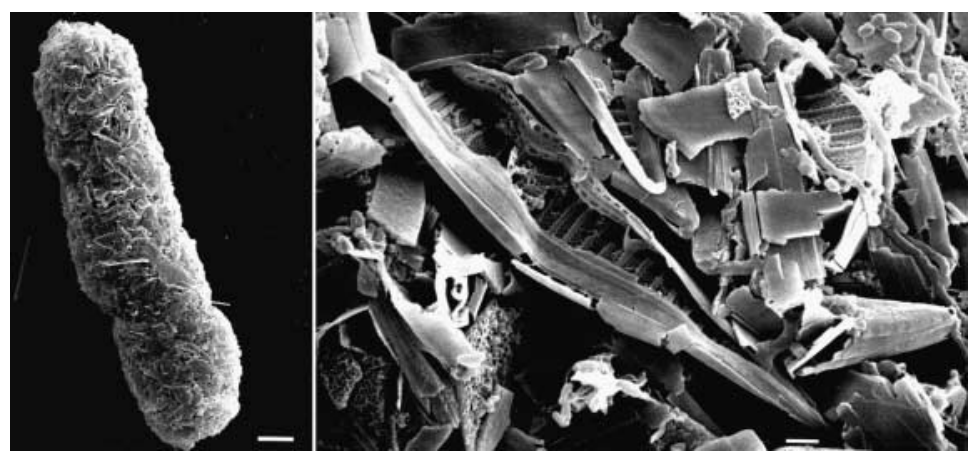

Fig. 1. Fecal pellet of the copepod Acartia tonsa produced while feeding on the toxic diatom Pseudo-nitzschia multiseries. Photograph at left shows entire fecal pellet; line scale $=10 \mu \mathrm{m}$. Photograph at right is high magnification, showing fragments of broken diatoms; scale bar $=1 \mu \mathrm{m}$

lithophorid and diatom cells in fecal pellets of salps and pteropods that appeared intact based upon scanning electron microscopy of external morphology, but transmission electron microscopy revealed that internal protoplasm had been digested. Cells that appear to be identical to the aphotic zone 'olive-green cells' described by Fournier $(1970,1971)$ have been found in fecal pellets of salps and pteropods by Silver \& Bruland (1981) and bathypelagic marine snow (Silver \& Alldredge 1981). These were suggested to be waste products from either partial degradation of algae ingested by herbivores, cells that had undergone autolysis, egested vacuolar residues of protozoans or fecal pellets of microzooplankton,

(Honjo \& Roman 1978, Turner 1979, Welschmeyer et al. 1984, Downs \& Lorenzen 1985, Welschmeyer \& Lorenzen 1985, Vernet \& Lorenzen 1986, Bathmann \& Liebezeit 1987, Dagg \& Walser 1987, Morales 1987, Head 1988, Head et al. 1988, Sapozhnikov \& Pasternak 1988, Dagg et al. 1989, Nelson 1989, Ayukai 1990, González \& Biddanda 1990, Roy \& Poulet 1990, Head 1992a,b, Head \& Harris 1992, 1996, Lee \& Fisher 1992, Head \& Horne 1993, Otsuki et al. 1993, Pfannkuche \& Lochte 1993, Anderson 1994, Butler \& Dam 1994, Harris 1994, Landry et al. 1994a,b, Madin et al. 1997, Urban-Rich et al. 1998, McLeroy-Etheridge \& McManus 1999, Thibault et al. 1999, Goericke et al. 2000, Hayashi et al. 2001). Altabet \& Small (1990) found that nitrogen isotope ratios in zooplankton fecal pellets indicated that grazers were important modifiers of nitrogen contents of particles sinking in the sea. Copepod fecal pellets can also be highly concentrated sources of dimethylsulfoniopropionate (DMSP) (Kwint et al. 1996, Tang 2001) and may be important in the vertical flux of this compound (Daly \& DiTullio 1996).

The feeding ecology of various zooplankters has been related to rates of production, size, volume and enzymatic activity of fecal pellets (Clarke et al. 1988, Butler \& Dam 1994, Harris 1994, Paffenhöfer 1994, Bochdansky et al. 1995, Dagg 1995, Carlotti et al. 1997, Nejstgaard et al. 1997, Rey et al. 1999, Thibault et al. 1999, Huskin et al. 2000), and sizes of fecal pellets have been examined in relation to sizes of fecal pellet producers (Uye \& Kaname 1994).

There have been several reports of intact or even live phytoplankton cells in fecal pellets. Johnson et al. (1982) found intact Synechococcus cells in Calanus sp. fecal pellets, and ultrastructural studies revealed that the cells were apparently undigested. Pfannkuche \& Lochte (1993) found apparently undigested chlorophyll-bearing cyanobacteria cells in salp feces. Conversely, Silver \& Bruland (1981) observed many coccowhich had been eaten by consumers, evacuated in fecal pellets and then after subsequent fecal pellet sinking and degradation were released back into the water column at depth. The finding of photosynthetically competent phytoplankton cells from $1000 \mathrm{~m}$ prompted Platt et al. (1983) to suggest that the cells had reached depth after surviving grazer gut passage and fecal pellet sinking and decomposition.

The existence of viable phytoplankton cells in euphausiid fecal pellets was confirmed by Fowler \& Fisher (1983). Fecal pellets from sediment traps as well as those produced by euphausiids grazing on laboratory diets contained live cells, mostly diatoms. Viability was confirmed by growth of cells both in fecal pellets and subsequently in unenriched seawater. In some cases, cells had survived in natural fecal pellets for up to $10 \mathrm{~d}$.

Bathmann \& Liebezeit (1986) found that many fecal pellets produced by copepods during a declining spring phytoplankton bloom in the Baltic contained high levels of chlorophyll a (chl a) but low levels of phaeopigments, indicating that pellets contained undigested cells. Scanning electron microscopy of these fecal pellets confirmed that they contained abundant intact diatom cells. As the bloom became terminated, chl $a$ and intact diatoms in copepod fecal pellets progressively declined.

The lipid, amino acid and fatty acid contents of fecal pellets of copepods, euphausiids and other consumers can differ with changes in the levels of these compounds in ingested food or with fecal pellet age (Tanoue et al. 1982, Prahl et al. 1984a,b, 1985, Tanoue 1985a,b, Corner et al. 1986, Matsueda et al. 1986, Neale et al. 1986, Poulet et al. 1986, Tanoue \& Hara 1986, Bradshaw et al. 1989, Wakeham \& Lee 1989, Roy \& Poulet 1990, Claustre et al. 1992, Marty et al. 1994, Yoon et al. 1996, Hamm et al. 2001). Fecal pellets of the pelagic crab Pleuroncodes planipes accounted for a 
significant portion of the lipids collected in sediment traps deployed over the upper $1500 \mathrm{~m}$ in the equatorial North Pacific (Wakeham \& Canuel 1986).

\section{Fecal pellets and pollutants}

Anthropogenic compounds showing elevated concentrations in fecal pellets or other sedimented materials (in addition to references in Turner \& Ferrante [1979] for trace metals, radionuclides, chlorinated hydrocarbons and petroleum hydrocarbons) include polycyclic aromatic hydrocarbons (Prahl \& Carpenter 1979), chlorinated hydrocarbons (Osterroht \& Smetacek 1980, Sleeter \& Butler 1982, Burns et al. 1985, Fowler et al. 1986, Harding 1986, Knap et al. 1986), petroleum hydrocarbons (Burns et al. 1985, Broman et al. 1987), fly-ash particles from coal-burning power plants (Deuser et al. 1983b), metals (Cowen \& Bruland 1985, Krishnaswami et al. 1985, Noriki et al. 1985a,b, Fisher et al. 1991, Reinfelder \& Fisher 1991, Nott \& Nicolaidou 1996), transuranics (Fowler et al. 1983, Gorsky et al. 1984, Reinfelder \& Fisher 1991, Reinfelder et al. 1993, Lee \& Fisher 1994) and radionuclides (Fowler et al. 1983, 1987, Livingston \& Anderson 1983, Bacon et al. 1985, Krishnaswami et al. 1985, Harada \& Tsunogai 1986, Buessler et al. 1987, Kempe \& Nies 1987, Kempe et al. 1987, Fisher et al. 1988, Kusakabe et al. 1988, Moore \& Dymond 1988, Reinfelder et al. 1993).

The Chernobyl nuclear power plant accident on 26 April 1986 provided a serendipitous 'tracer experiment' for measuring vertical flux of radionuclides into the deep sea at 3 distant European locations (Bacon 1987). Fowler et al. (1987) recorded peaks of the signature radionuclides ${ }^{141} \mathrm{Ce}$ and ${ }^{144} \mathrm{Ce}$ from Chernobyl in zooplankton fecal pellets in time-series sediment traps at $200 \mathrm{~m}$ in the Mediterranean off Corsica from 8 to 15 May, within a few days of delivery of these radionuclides to the surface by a pulse of rainfall on 4 to 5 May. The sediment traps had been deployed prior to the Chernobyl event, and their particulates were primarily $(>70 \%)$ composed of zooplankton fecal pellets in the size range of those produced by copepods. Kempe \& Nies (1987) and Kempe et al. (1987) also recorded Chernobyl radionuclides within $10 \mathrm{~d}$ in sediment traps already in place at $222 \mathrm{~m}$ depth in the North Sea off Norway. This was during the time of the spring diatom bloom. Chernobyl radionuclides were also recorded in sediment traps deployed in the Black Sea prior to the accident (Buessler et al. 1987, Kempe et al. 1987). Radionuclides arrived at a depth of $1071 \mathrm{~m}$ over the course of the 2 months following the accident, during the time of the normal summer bloom of the coccolithophorid
Emiliania huxleyi. Kusakabe et al. (1988) also recorded Chernobyl radionuclides at depths of 110 to $780 \mathrm{~m}$ in June and July of 1986 in the North Pacific and Bering Sea, indicating long-distance transport over several months. Levels of Chernobyl radionuclides in sediment traps in the Black Sea continued to decline throughout the fall and winter of 1986, and by a year after the explosion were undetectable (Buesseler et al. 1990). The Chernobyl episode clearly showed that biologically mediated vertical flux mechanisms in the sea can deliver pollutants to depth with previously unappreciated rapidity.

\section{Fate of fecal pellets}

'Utilization of fecal particles would appear to be a race between microorganisms and coprophages, both working against the effects of gravity on the falling particles.'

Pomeroy et al. (1984) p. 434

There is increasing evidence that many zooplankton fecal pellets are recycled in the water column through microbial decomposition and coprophagy. Urban-Rich et al. (1999) compared potential fecal pellet carbon flux, determined from fecal pellet production rates, fecal pellet carbon and zooplankton abundance, with actual levels of carbon flux due to zooplankton fecal pellets recovered from sediment traps off Norway (see Wassmann et al. 1999). Potential fecal pellet carbon flux was estimated to be 2 to as much as $>100 \%$ of the measured fecal pellet carbon flux in the upper $200 \mathrm{~m}$, but recovery of fecal pellets in sediment traps, which amounted to only 5 to $35 \%$ of total carbon flux, suggested that substantial recycling of fecal pellets was occurring in surface waters. Using a similar approach, Viitasalo et al. (1999) calculated that $>99 \%$ of potential copepod fecal pellet production in the Baltic was recycled in the upper water column, although this varied somewhat with season, location, composition of the zooplankton community and turbulence. Much of the loss of fecal pellet carbon in the water column appears to be through release of dissolved organic carbon from fecal pellets during their descent (Noji et al. 1999a, Urban-Rich 1999, 2001). Also, despite extensive biodegradation (>98\%), the bulk organic composition of sinking particulate matter appears to undergo minimal changes (Hedges et al. 2001), suggesting that organic matter in sinking particles such as fecal pellets might be protected from degradation by inorganic components.

Some zooplankton fecal pellets become repackaged through coprophagy by other zooplankters. Gowing \& Silver (1986) have found recognizable zooplankton fecal pellets in the guts of deep-sea copepods. Paffenhöfer \& Knowles (1979) and Ayukai (1986) have shown 
that adult copepods feed upon fecal pellets of conspecific juveniles, often at higher filtering rates than on co-occurring diatoms. Neal et al. (1986) fed fecal pellets of barnacle nauplii to copepods. Green et al. (1992) found that nauplii of the large copepod Calanus helgolandicus ingested fecal pellets of nauplii of the smaller copepod Pseudocalanus elongatus.

Lampitt et al. (1991) reported that copepods break up their own fecal pellets while ingesting only a small portion of the pellets, and named this behavior 'coprorhexy.' These authors speculated that copepods strip the peritrophic membrane off fecal pellets and consume the membrane in order to ingest attached microbiota. Indeed, Youngbluth (1982) observed mysis larvae of pelagic shrimps feeding on microbes, phytoplankton, protozoans and metazoans attached to the peritrophic membrane of their own fecal material, as well as fecal pellets of other zooplankters.

Noji et al. (1991) distinguished 3 types of behavior by copepods when feeding on fecal pellets, all of which can potentially modify particle-size spectra of particle assemblages. Coprorhexy, or the fragmentation of fecal pellets, resulted in decreasing the number of large particles and increasing the abundance of smaller particles. At the same time, the smallest size fractions of particles had an increase in particle sizes, due to addition of larger particles from broken fecal pellets, which were larger than the small natural particles most abundant in the water. Coprophagy, or ingestion of fecal pellets, removes large particles. 'Coprochaly' was defined as disruption of peritrophic membranes of fecal pellets by copepods, resulting in partial dispersal of fecal pellet contents into the water, thereby increasing the relative abundance of small particles. Noji et al. (1991) suggested that disruption of fecal pellets by these processes would increase residence times of fecal materials by converting large particles to smaller ones with lower sinking rates. This could also enhance microbial degradation of feces by increasing microbial substrate by converting larger particles to smaller ones. Additional effects might include enhancement of diffusion processes oxygenating the interior of fecal particles (Alldredge \& Cohen 1987), as well as leaching of dissolved organics and inorganics from such particles to the surrounding water (Jumars et al. 1989). All of these processes would be expected to convert large fast-sinking particles to smaller suspended ones, thereby increasing the recycling of fecal pellets in the upper layers of the sea, while retarding their transport to depth.

The copepod Oithona similis has been shown to ingest fecal pellets of several calanoid copepods, whereas the calanoids did not appreciably ingest their own fecal pellets (González \& Smetacek 1994, González et al. 1994b). This led González \& Smetacek
(1994) to speculate that specialization for coprophagy by $O$. similis may contribute to the ubiquitous abundance of this species in the ocean. Coprophagy of fecal pellets produced by calanoid copepods by cyclopoids (mainly Oithona spp.) was also indicated by results from mesocosm studies of Svensen \& Nejstgaard (2001).

There is also indirect evidence for zooplankton reprocessing of fecal pellets by coprophagy at depth. Honjo (1978) collected 'green' and 'red' fecal pellets in sediment traps in the Sargasso Sea, which had different composition. The green pellets contained abundant phytoplankton pigments, coccoliths and diatom fragments, and appeared to have resulted from zooplankton grazing in the surface layer, with rapid sedimentation to depth. The red pellets, however, contained clay particles and few phytoplankton remains, and were collected only in the deepest sediment traps. Honjo (1978) concluded that red pellets had been produced at depth by deep-water zooplankters reprocessing fecal pellets and other particulates sinking from above. Similarly, Urrère \& Knauer (1981) found an increased fecal pellet flux in sediment traps at $1500 \mathrm{~m}$, relative to traps at $500 \mathrm{~m}$, and Conte et al. (2001) found increased lithogenic fluxes between 500 and $3200 \mathrm{~m}$ compared to depths closer to the surface. Both of these increases in fluxes at depth suggested repackaging of fecal pellets through coprophagy by mesopelagic and bathypelagic zooplankton.

Fecal pellets are subject to microbial decomposition, and questions have been raised as to whether fecal pellets contain bacteria primarily on surfaces or internally, and whether pellet decomposition is primarily from the 'inside out' or from the 'outside in'.

There is increasing evidence for decomposition of fecal pellets by internal bacteria. Gowing \& Silver (1983) confirmed that natural fecal pellets collected from either sediment traps or freshly produced by pelagic crabs contained bacteria primarily inside the pellets, and that pellet surfaces had few attached bacteria. This was in contrast to observations of laboratory-produced fecal pellets, which were reported to have few internal bacteria (Honjo \& Roman 1978). Further, Gowing \& Silver (1983) discovered that with aging in the laboratory, fecal pellets that initially had few surface bacteria developed a 'surface microbial lawn' over time during laboratory incubations, similar to observations of Turner (1979). Gowing \& Silver (1983) concluded that extensive rapid bacterial colonization of fecal pellet surfaces was likely an artifact of laboratory conditions, and that decomposition of most fecal pellets in the sea initiates with internal bacteria that are either enteric or ingested, or both. Since guts of copepods have been reported to contain an extensive microbial flora (Ogawa 1977, Sochard et al. 1979), 
Gowing \& Silver (1983) concluded that fecal pellet decomposition in the sea is primarily from the inside out. However, Nott et al. (1985) reported that bacteria were present in copepod fecal pellets only during periods of feeding, and no bacteria were found in empty guts of non-feeding copepods, suggesting that bacteria in fecal pellets were ingested along with food and not derived from resident populations in the gut. Lawrence et al. (1993) concluded that bacteria were abundant in copepod fecal pellets produced from feeding on food that contained bacteria, but bacteria were absent from fecal pellets produced from feeding on axenic food. Bacteria within copepod fecal pellets grew during incubation, suggesting that some had survived gut passage, and high aminopeptidase activity in fecal pellets suggested that internal bacteria participated in pellet degradation. Nagasawa \& Nemoto (1988) found bacteria in the guts, within the interior of fecal pellets and colonizing the outside of fecal pellets of marine amphipods and copepods. In some cases, bacteria within copepod fecal pellets were more abundant than, and taxonomically different from, bacterial assemblages in surrounding waters (Delille \& Razouls 1994). Hansen \& Bech (1996) observed that copepod fecal pellets became colonized by bacteria from the surrounding water but could not dismiss the possibility that some bacteria were from inside fecal pellets or copepod guts.

Bianchi et al. (1992) identified both methanogenic (obligate anaerobes) and nitrifying (areobic) bacteria in natural fecal pellets from sediment traps and copepods, and suggested that the bacteria originated from copepod guts, most likely as ingested species for nitrifiers and enteric for methanogens. Karl \& Tilbrook (1994) concluded that most methane in the upper layers of the Pacific is associated with sinking particles, and suggested that methane leaking from settling fecal pellets into the water column may explain the typical supersaturation of highly oxygenated surface waters with methane that forms only under anaerobic conditions.

Raghukumar \& Raghukumar (1999) discovered that salp fecal pellets in the Arabian Sea contained abundant bacteria and unicellular, heterotrophic fungoid protists known as thraustochytrids. In addition to internal thraustochytrids, during experimental incubations, fecal pellets became colonized by thraustochytrids that were in the water column. Isolates of these protists from fecal pellets grew during incubations designed to simulate temperature and pressure conditions of the deep sea. This suggests that thraustochytrids survive gut passage through salps and continue to decompose salp fecal pellets during their rapid descent to the abyss.

Some fecal pellets have been shown to become rapidly colonized by bacteria and other microorgan- isms from seawater. Jacobsen \& Azam (1984) found that within $24 \mathrm{~h}$ of egestion copepod fecal pellets had bacteria from the surrounding seawater covering nearly a third of the fecal pellet surface area. Sinking of pellets through a column of natural seawater increased the rate of initial colonization compared to fecal pellets lying on the bottoms of laboratory containers. Growth rates of bacteria associated with fecal pellets and those of bacteria free in the water were not significantly different, and mineralization of fecal pellet carbon amounted to no more than $1 \% \mathrm{~d}^{-1}$. Jacobsen \& Azam (1984) concluded that bacteria colonizing fecal pellets may not be a major remineralization pathway in the epipelagic.

Guidi \& Tito de Morais (1983) observed that both fresh and aged fecal pellets of an ascidian were ingested by an epibenthic amphipod and that aged fecal pellets became progressively colonized by bacteria, which increased pellet organic carbon content. Peduzzi \& Herndl (1986) also confirmed that fecal pellets of a gastropod became quickly colonized by bacteria within $12 \mathrm{~h}$, after which bacterial abundance on pellets declined.

There is a microbial succession of colonizers of fecal pellets. Pomeroy et al. (1984) observed that bacteria originating in feces of salps and doliolids developed rapidly within the first $24 \mathrm{~h}$, causing increases in respiration, net uptake of phosphate, loss of total primary amines and little change in ammonium. After $24 \mathrm{~h}$ protozoans invaded the feces and rapidly consumed most bacteria. After about $2 \mathrm{~d}$ fecal pellet microbial activity had largely ceased. Pomeroy et al. (1984) concluded that the efficiency of conversion of tunicate feces to microbial biomass was 10 to $20 \%$ and that fecal pellets were rapidly biodegraded by their own internal microbial community. In contrast, Caron et al. (1989) found that fecal pellets of oceanic salps remained intact over $10 \mathrm{~d}$ periods of experimental decomposition, despite becoming colonized by abundant bacteria and protozoans. Silver et al. (1984) also found that detrital particles collected in sediment traps had abundant ciliates, which were suggested to be endemics within consumer guts, rather than colonists from the surrounding water.

Fecal pellet degradation rates may depend on the diets producing the fecal pellets. Hansen et al. (1996) fed the copepod Acartia tonsa unialgal diets designed to simulate the boreal seasonal succession of phytoplankton dominated by diatoms in spring, nanoflagellates in summer and dinoflagellates in fall. Fecal pellets produced on diatom diets degraded significantly more slowly than those produced on nanoflagellate or dinoflagellate diets. Bacteria decreased over time on diatom-based pellets but increased on nanoflagellateand dinoflagellate-based diets. Hansen et al. (1996) 
concluded that flagellate-based fecal pellets produced during summer and fall periods are most likely degraded in the epipelagic, whereas diatom-based fecal pellets are more likely to sediment to the benthos in spring.

Smetacek (1980a) also found evidence for considerable reprocessing of copepod fecal pellets in Kiel Bight. The contribution of calanoid copepod fecal pellets to particulate carbon in detritus averaged $<10 \%$ from April through September and $<5 \%$ for the rest of the year. Periods of lowest fecal pellet contribution were those of highest zooplankton abundance and vice versa. Calculated residence times for fecal pellets in the $20 \mathrm{~m}$ deep water column were only a few hours in summer. Smetacek concluded that reprocessing of fecal pellets by zooplankton coprophagy and microbial degradation was high in summer and that this conserved essential nutrients in the water column.

Hofmann et al. (1981) simulated the contribution of fecal pellets by the various stages of dominant small copepods of the genus Paracalanus to the benthos of the southeastern USA continental shelf. The model indicated that nauplii produced daily averages of $50 \%$ of total fecal pellet mass, but only $4 \%$ of pellet flux. Adults produced daily averages of $13 \%$ of total fecal pellet mass but only $63 \%$ of pellet flux. Because most copepod fecal pellets were small, would sink slowly and were presumably consumed by coprophagy or microbially degraded in the epipelagic, the model indicated that only $0.2 \%$ of the average daily primary production reached the sea floor (35 $\mathrm{m}$ depth) as fecal pellets.

Krause (1981) suggested that most fecal pellets are biodegraded in near-surface waters and questioned the notion that fecal pellets sink at all. During a study of vertical distributions of fecal pellets in the North Sea, fecal pellets were generally found above the main thermocline, within $30 \mathrm{~m}$ of the surface. Most fecal pellets appeared to be those of the copepod Calanus finmarchicus. Even when this copepod migrated below the thermocline, the fecal pellet maximum remained in the uppermost layers of the water column. Krause (p. 325) conjectured that 'faecal pellets, probably enriched with bacteria in the gut of the copepod, inevitably have an anaerobic metabolism. The gas bubbles which develop during the bacterial activity in the faeces, at first cause a floating or even a buoyancy of the faecal pellets. This causes them to remain in the euphotic zone, where they can be re-cycled.' Krause then speculated that the high sinking rates for various types of fecal pellets recorded from laboratory investigations (references in Turner \& Ferrante 1979) were artifacts caused by such things as storage of fecal pellets in cold water or 'counting and measuring under a warm light microscope, where the material is heated.'
He concluded that fecal pellets remain in the upper mixed layer because they are, in fact, buoyant and do not naturally sink. This conclusion is at odds with the numerous studies conducted prior to his showing that fecal pellets are collected in deep-sea sediment traps. An alternative explanation might be that fecal pellets sometimes remain in the upper mixed layer because it is mixed. Indeed, Alldredge et al. (1987) observed that large fecal pellets, probably produced by euphausiids, had sustained residence times in the upper $20 \mathrm{~m}$ off California, even though these pellets had measured sinking rates of 18 to $170 \mathrm{~m} \mathrm{~d}^{-1}$. Alldredge et al. (1987) attributed this accumulation of large fecal pellets in surface waters to turbulent mixing, which retained the pellets in the upper mixed layer. Martens \& Krause (1990) also found that most fecal pellets were at depths above $100 \mathrm{~m}$ in the North Sea in summer.

\section{Microzooplankton fecal pellets}

Most studies of zooplankton fecal pellets have focused on pellets produced by larger mesozooplankters such as copepods, euphausiids and tunicates, which have high sinking rates. However, some microzooplankters such as protozoans and small metazoans are now known to produce tiny fecal pellets, which presumably do not sink and are likely remineralized in the epipelagic.

Gowing \& Silver (1985) discovered that small fecal pellets from 3 to $50 \mu \mathrm{m}$ in diameter were ubiquitous and abundant in sediment traps and water samples throughout the upper $2 \mathrm{~km}$ of the eastern tropical Pacific. These 'minipellets' were thought to be wastes of radiolarians, other protozoans and small metazoans. Fluxes of minipellets exceeded those of larger fecal pellets $(>50 \mu \mathrm{m})$ by 3 orders of magnitude, and carbon flux of minipellets was 11 to $49 \%$ that of larger pellets. Minipellets contained intact bacteria and picoplankton cells, some of which appeared identical to previously described olive-green cells. Gowing \& Silver (1985) concluded that minipellet producers are major reprocessors of detritus originating in the euphotic zone and that these organisms are important in biological transformation of organic matter in the sea.

Nöthig \& Bodungen (1989) observed that small fecal pellets (30 to $150 \mu \mathrm{m})$ were abundant in the water column and in sediment traps in the Weddell Sea. These pellets were suggested to originate from protozoan grazers such as ciliates, heterotrophic dinoflagellates, radiolarians and foraminiferans. They constituted $36 \%$ of the total sedimented feces volume in sediment traps. The majority of fecal pellets remaining in sediment traps were larger (150 to $300 \mu \mathrm{m})$ spherical fecal pellets, suggested to be those of small metazoans. 
Other studies have confirmed that protozoans produce minipellets. Stoecker (1984) found that tintinnids and aloricate ciliates produce small fecal aggregates $(18 \times 32 \mu \mathrm{m})$, which overlap in size with cells of their dinoflagellate prey $(16 \times 22 \mu \mathrm{m})$. Buck et al. (1990) confirmed that a phagotrophic athecate dinoflagellate found in Antarctic sea ice produced small fecal pellets that averaged $30 \mu \mathrm{m}$ in diameter and were filled with frustules of the pennate diatom Nitzschia cylindrus. Buck et al. (1990) suggested that the release of such fecal pellets from melting ice into the underlying water column may constitute a substantial portion of the flux of organics from the euphotic zone to depth. González (1992b) also found that minipellets (5 to $100 \mu \mathrm{m}$ ) were abundant in the Antarctic. These minipellets contained numerous unbroken diatom frustules and originated from heterotrophic unarmored dinoflagellates and phaeodarian radiolarians. Gowing et al. (2001) reported that minipellets from athecate heterotrophic dinoflagellates and ciliates were the dominant types of fecal pellets in sediment traps at several stations in the Ross Sea.

Dinoflagellate minipellets have also been reported from temperate localities. Buck \& Newton (1995) found that during a spring bloom in Dabob Bay (Puget Sound, Washington, USA) the dominant diatom Thalassiosira pacifica was extensively eaten by an unarmored dinoflagellate of the genus Gymnodinium, which produced abundant fecal pellets. These pellets averaged $69 \times 83 \mu \mathrm{m}$, were covered with a peritrophic membrane and were packed with Thalassiosira frustules, which were devoid of cytoplasm. Dinoflagellate minipellets accounted for an average of $29 \%$ of the total fecal pellet flux to $50 \mathrm{~m}$ depth. Elbrächter (1991) showed that a variety of photosynthetic and heterotrophic dinoflagellates and other protists produce minipellets.

Other studies have revealed abundance of fecal pellets from metazoan microzooplankton. Minipellets from copepod nauplii also contained frustules of the diatom Nitzschia sicula during a bloom of this species in the Adriatic (Vilicic et al. 1994), and pellets $<80 \mu \mathrm{m}$ in the longest dimension, likely from copepod nauplii, were important components of the fecal pellet assemblage in a Norwegian fjord (Pasternak et al. 2000).

\section{Fish fecal pellets}

The fecal pellets of fish also appear to be important in some marine ecosystems. Fecal matter of 7 species of mid-water fish sank at rates of hundreds to thousands of meters per day (Robison \& Bailey 1981), and pellets of larger volumes sank faster. Due to the high abundance of mid-water fish in many oceanic environments and the high nutrient content of their fecal pellets, mid-water fish fecal matter may be a major source of organic export from the pelagic community to the benthos. Bray et al. (1981) have shown that fish that forage during the day on pelagic zooplankton and then return to shelters in a rocky reef at night import substantial amounts of carbon to the reef through defecation in nocturnal shelters. Fecal pellets of reef fishes also appear important in the import of minerals to reef communities (Geesey et al. 1984). Similarly, Robertson (1982) showed that many coral reef fishes are coprophagous on feces of other fish, which can have high nutritional content (Bailey \& Robertson 1982). Fecal pellets of reef fishes that prey on cnidarians that contain zooxanthellae, themselves contain live zooxanthellae, which are photosynthetically active and capable of re-establishing symbioses with cnidarians (Parker 1984).

Fecal matter of anchovies in the Peru upwelling system was a major component of the downward flux into sediment traps (Staresinic et al. 1983). Fecal fragments sank at rates averaging $>1 \mathrm{~km} \mathrm{~d}^{-1}$, and had high organic carbon and nitrogen contents as well as abundant diatom fragments. Due to fast sinking rates, anchovy feces have a relatively short residence time in the water column, and since they fall into sediments that are primarily anoxic below the superficial layers, fecal organic matter should remain intact before burial in deeper sediments. Staresinic et al. (1983) speculated that the decline in anchovy stocks off Peru in the early 1970s might have led to reduced fluxes of particulate organic matter and that a relative increase in the contribution of smaller slower-sinking particles such as phytoplankton cells and zooplankton fecal pellets might have contributed to the increased denitrification recorded off coastal Peru since the decline of fish stocks (Codispoti \& Packard 1980). An alternative hypothesis by Walsh (1981) suggested that the decline in anchovy stocks off Peru would decrease utilization of organic matter in the water column by anchovies, making more organic matter available for deposition. Either way, feeding and fecal production by anchovies off Peru, and presumably in other coastal upwelling systems, are potentially important processes. In fact, Scheidegger \& Krissek (1983) have suggested that unusually fine-grained terrigenous sediments confined to the inner continental margin off Peru are due to fecal pelletization of these particles by zooplankton and anchovies while feeding upon phytoplankton. Since zooplankton and fish populations increase together with phytoplankton during enhanced upwelling intensity in December through April, also a period of peak river discharge, the coincidence of maximum biological removal of terrigenous sediments at 
the time of their maximum input may explain why so few terrigenous sediments are found beyond the continental margin. Scheidegger \& Krissek (1983) concluded that such a biological 'filter' or barrier to seaward transport of terrigenous sediments in the wind-driven surface layer enhanced deposition of terrigenous and pelagic particulates into anoxic sediments off Peru, thereby helping to preserve the sedimentary record of upwelling characterized by various chemical and biological indicators (references in Scheidegger \& Krissek 1983).

\section{Zooplankton fecal pellets in ancient oceans}

There is paleontological evidence for zooplankton fecal pellets. Porter \& Robbins (1981) discovered what appear to be fossil zooplankton fecal pellets in black shales 11 to 300 million yr old that represent coastal, epicontinental sea and lake environments. These black shales are associated with phosphate, oil and coal deposits. Porter \& Robbins (1981) suggested that zooplankton fecal pellets contributed to the deposition of organic matter in anoxic basins, contributing to formation of the black shale deposits. Robbins et al. (1985) described microfossils resembling fecal pellets of modern zooplankters in Middle Cambrian and Early Proterozoic shale. These microfossils were in rocks that also preserved sulfides analogous to modern anoxic environments that preserve fecal pellets. Rocks containing putative pellets were $0.53 \times 10^{9}$ to $1.9 \times 10^{9} \mathrm{yr}$ old. Similar rocks of Archaean age $\left(2.68 \times 10^{9}\right.$ to $3.8 \times$ $10^{9} \mathrm{yr}$ old) did not contain pellet-like microfossils. Robbins et al. (1985) argued that if the Proterozoic microfossils were fossilized fecal pellets, then they provided evidence of metazoan life and a complex food web $1.9 \times 10^{9} \mathrm{yr}$ ago, which predates macroscopic metazoan body fossils $0.67 \times 10^{9} \mathrm{yr}$ ago, animal trace fossils $0.9 \times 10^{9}$ to $1.3 \times 10^{9} \mathrm{yr}$ ago and fossils of unicellular eukaryotic algae $1.4 \times 10^{9} \mathrm{yr}$ ago.

Fecal pellets may have facilitated oxygenation of the ocean, leading to the Cambrian 'explosion' of multicellular life (Walter 1995, Oliwenstein 1996). G. A. Logan et al. (1995) found that hydrocarbons extracted from Terminal Proterozoic to Early Cambrian marine sediments (570 to 590 million yr old) were derived mainly from bacteria and other heterotrophs rather than from autotrophs. They proposed that prior to the Cambrian, slowly sinking organic matter in the sea was repeatedly reworked by bacterial degradation, leading to sulfate reduction and oxygen depletion in the surface layer of the sea. High ${ }^{13} \mathrm{C}:{ }^{12} \mathrm{C}$ ratios in sediments suggested long heterotrophic microbial food webs. An abrupt decline in ${ }^{13} \mathrm{C}:{ }^{12} \mathrm{C}$ ratios at the beginning of the Cambrian, coincident with evolution of the metazoan gut, suggests that organic matter in the sea became increasingly packaged in rapidly sinking fecal pellets, which plummeted to depth before they could be extensively decomposed, resulting in increases in ocean oxygenation and allowing the Cambrian radiation of multicellular animal life.

Butterfield (1997) has proposed that the advent of metazoan guts and increased zooplankton grazing in the sea at the Proterozoic-Cambrian interface would have had the opposite effect from that described above, namely a decrease in export to depth via zooplankton fecal pellets. By removing phytoplankton and packaging it as animal biomass, which stayed in the upper water column, Butterfield suggested that zooplankton grazing might have reduced carbon burial, causing the observed drop in ${ }^{13} \mathrm{C}:{ }^{12} \mathrm{C}$ ratios at the beginning of the Cambrian. If this were the case, then the drop in carbon ratios would be a consequence, rather than a cause, of the Cambrian explosion.

Kitchell (1983) and Haberyan (1985) have suggested that if zooplankton fecal pellet sedimentation is a dominant means by which phytoplankton remains reach the seafloor and become part of the micropaleontological fossil record, then selective feeding by the zooplankton producing the fecal pellets might heavily bias the fossil record toward phytoplankton species preferred by grazers.

\section{The variable importance of fecal pellets in sedimentary flux}

Numerous studies have shown that the contribution of zooplankton feces to sedimentary flux can be substantial (Table 3). Bishop et al. (1977) estimated that in the upper $400 \mathrm{~m}$ of the equatorial Atlantic, zooplankton fecal pellets and fecal matter constituted only $4 \%$ of the total suspended mass concentration but accounted for $99 \%$ of the vertical mass flux through the upper $388 \mathrm{~m}$. Urrère \& Knauer (1981) reported that fluxes of recognizable zooplankton fecal pellets varied with depth, accounting for 10 to $19 \%$ of total carbon fluxes for near-surface waters ( 35 to $150 \mathrm{~m}$ ), declining to $9.7 \%$ at $500 \mathrm{~m}$ and $3.4 \%$ at $1500 \mathrm{~m}$. Fowler et al. (1991) found that fecal pellet carbon fluxes increased with depth, accounting for 25,29 and $33 \%$ of total particulate carbon fluxes at 50, 150 and $250 \mathrm{~m}$, respectively. Graf (1989) concluded that a pulse of fecal pellets from the copepod Calanus finmarchicus accounted for $92 \%$ of the total carbon settling to the deep North Atlantic at the end of a spring bloom in May. Fecal pellets constituted averages of 11 to $37 \%$ but up to $66 \%$ of the vertical flux of particulate organic carbon (POC) over the upper $200 \mathrm{~m}$ off Norway (Wassmann et al. 1999). Roy et al. (2000) found that zooplankton fecal 
Table 3. Zooplankton fecal pellet contribution to total particulate organic carbon flux

\begin{tabular}{|c|c|c|c|}
\hline \multicolumn{2}{|c|}{ Depth (m) } & Fecal pellets (\%) & Source \\
\hline \multicolumn{4}{|c|}{ High } \\
\hline \multicolumn{2}{|l|}{1430} & 92 & Graf (1989) \\
\hline \multicolumn{2}{|l|}{200} & Up to 66 & Wassmann et al. (1999) \\
\hline \multicolumn{2}{|l|}{150} & 3 to $>100$ & Roy et al. (2000) \\
\hline \multicolumn{2}{|l|}{120} & 'Almost all' & Small et al. (1983) \\
\hline \multicolumn{2}{|l|}{400} & $99 \%$ of total mass & Bishop et al. (1977) \\
\hline \multicolumn{2}{|l|}{200} & 92.8 (sum of all sizes) & Wassmann et al. (2000) \\
\hline \multicolumn{2}{|l|}{1500} & 34.0 (sum of all sizes) & Wassmann et al. (2000) \\
\hline \multicolumn{4}{|l|}{ Low } \\
\hline \multicolumn{2}{|c|}{389 to 5068} & 5 to 10 & Pilskaln \& Honjo (1987) \\
\hline \multicolumn{2}{|c|}{74} & 2 to 25 & Maita et al. (1988) \\
\hline \multicolumn{2}{|l|}{390} & 'Insignificant' & Asper (1987) \\
\hline \multicolumn{2}{|l|}{200} & 6 & Taylor (1989) \\
\hline \multicolumn{2}{|l|}{100} & 0.4 to 1.7 & Ayukai \& Hattori (1992) \\
\hline \multicolumn{2}{|l|}{42} & $<1$ & Lane et al. (1994) \\
\hline \multicolumn{2}{|l|}{500} & ean 20 , range 10 to 30 & Passow et al. (2001) \\
\hline \multicolumn{4}{|c|}{ Moderate to variable } \\
\hline \multicolumn{2}{|c|}{100} & 10 to 19 & Urrère \& Knauer (1981) \\
\hline \multicolumn{2}{|l|}{500} & 10 & Urrère \& Knauer (1981) \\
\hline \multicolumn{2}{|l|}{1500} & 3 & Urrère \& Knauer (1981) \\
\hline \multicolumn{2}{|l|}{50} & 25 & Fowler et al. (1991) \\
\hline \multicolumn{2}{|l|}{150} & 29 & Fowler et al. (1991) \\
\hline \multicolumn{2}{|l|}{250} & 33 & Fowler et al. (1991) \\
\hline \multicolumn{2}{|l|}{2300} & 3 to 35 & Carroll et al. (1998) \\
\hline \multicolumn{2}{|l|}{1000} & 1.6 to 62.0 & Miquel et al. (1994) \\
\hline \multicolumn{2}{|l|}{860} & 18 to 199 & Small \& Ellis (1992) \\
\hline \multicolumn{2}{|l|}{500} & 10 to $30 \%$ & Bauerfeind et al. (2001) \\
\hline \multirow[t]{3}{*}{300} & Pre-El Niño & 5 to 10 & González et al. (2000a) \\
\hline & El Niño & 24 to 38 & González et al. (2000a) \\
\hline & Post-El Niño & 3 to 11 & González et al. (2000a) \\
\hline 200 & & 5 to 48 & $\begin{array}{l}\text { Gowing et al. (2001), } \\
\text { Asper \& Smith (1999) }\end{array}$ \\
\hline
\end{tabular}

pellets accounted for 3 to $>100 \%$ of total POC flux over the upper $150 \mathrm{~m}$ in the Gulf of St. Lawrence but that during June, the period of maximum fecal pellet carbon flux, all values were $>66 \%$. The average contribution of zooplankton fecal pellets to POC flux at $50 \mathrm{~m}$ in this study was $50 \%$ over the annual cycle. Other studies show that euphausiid and copepod fecal pellets can be the dominant components of flux during major blooms of the prymnesiophyte Phaeocystis pouchetii (Lutter et al. 1989, Riebesell et al. 1995, Hamm et al. 2001) and coccolithophorids such as Emiliania huxleyi (van der Wal et al. 1995, Fischer et al. 1996).

Small et al. (1983) investigated the proportions of vertical particulate flux made up of fecal pellets and amounts of primary production converted by zooplankton to fecal pellets and dissolved excretions in the tropical Pacific. Both small $(<300 \mu \mathrm{m})$ and large (300 to $500 \mu \mathrm{m}$ ) zooplankton (not counting euphausiids, salps and red crabs) constituted $<2 \%$ of daily primary carbon and nitrogen production into fecal pellets. If all such fe- cal pellets sank below $100 \mathrm{~m}$ and into the oxygen minimum zone without being eaten or decomposed, then upward nutrient flux from below $100 \mathrm{~m}$ would only have to be equivalent to a loss of $2 \%$ or less to maintain daily production. That would mean that 'new production' (Dugdale \& Goering 1967, Eppley \& Peterson 1979) would have to be only $2 \%$ of total production, and $98 \%$ could be recycled production, if the only losses were due to sedimentation of fecal pellets from small and large zooplankton (mostly copepods). Considering that there are other fecal pellet producers and that some small fecal pellets are recycled in the epipelagic and do not sink below $100 \mathrm{~m}$, whereas other small pellets are exported to depth via attachment to marine snow, Small et al. (1983) estimated that total fecal pellet removal of carbon and nitrogen from surface waters would not exceed $10 \%$ of daily primary production and would more closely approximate $5 \%$. The percentages of vertical flux measured at $120 \mathrm{~m}$ composed of various types of fecal pellets were much greater. Small et al. (1983) estimated that $41 \%$ of the carbon flux to this depth came from fecal pellets of small and large zooplankton, and that $21 \%$ came from the red crab Pleuroncodes planipes. Small et al. (1983) concluded that after adding contributions from all other organisms that were not accounted for in these categories, 'almost all' of the carbon flux to $120 \mathrm{~m}$ could result from fecal pellet flux.

Other studies have shown the proportion of vertical fluxes attributable to fecal pellets is comparatively low. Despite collection of large numbers of zooplankton fecal pellets in sediment traps at various depths, fecal pellets contributed averages of only $<5$ to $10 \%$ of the vertical fluxes of organic, carbonate, silicate and lithogenic materials at several oceanic deep-water sites (Pilskaln \& Honjo 1987). However, since fecal pellets had elevated C:N ratios and high organic content, they may have been an important source of organic carbon for deep-sea benthos. Fecal pellet fluxes accounted for only 2 to $4 \%$ and 5 to $25 \%$ of the total organic carbon fluxes in summer and winter, respectively, to a depth of $74 \mathrm{~m}$ in Funka Bay, Hokkaido (Maita et al. 1988). Particulate flux to $390 \mathrm{~m}$ in the Panama Basin was dominated by marine snow, and fecal pellet flux was insignificant (Asper 1987). Taylor (1989) found that fecal pellet flux was only $6 \%$ of total particulate carbon flux in the upper $200 \mathrm{~m}$ in the North Pacific central gyre, and Ayukai \& Hattori (1992) reported that fecal pellet carbon flux was only 0.4 to $1.7 \%$ of total POC flux to $100 \mathrm{~m}$ off Japan. Lane et al. (1994) estimated that copepod fecal pellet flux in the upper $42 \mathrm{~m}$ over the Virginia continental shelf 
constituted $<1 \%$ of total particulate carbon collected in sediment traps and $0.3 \%$ of particulate carbon in the water column. The contribution of zooplankton feces to particulate carbon flux at 80, 200 and 1000 m depths in the Mediterranean was variable over the annual cycle (1.6 to $62 \%$ ) (Miquel et al. 1994). Similarly, Carroll et al. (1998) found that fecal pellet flux over $2300 \mathrm{~m}$ in the Mediterranean varied with depth and season, and in terms of types of fecal pellets collected, and that the proportion of total carbon flux attributable to fecal pellets averaged $18 \%$, ranging from 3 to $35 \%$. Lundsgaard \& Olesen (1997) concluded that most copepod fecal pellets produced in the Kattegat sank out of the surface layer but that, due to the large component of vertical flux from sources other than copepod fecal pellets, copepod fecal pellet contribution to flux was insignificant. Roman \& Gauzens (1997) calculated that the proportion of export flux due to copepod fecal pellets in the equatorial Pacific was small, suggesting that most copepod fecal pellets produced in the euphotic zone decomposed or were ingested by other zooplankton. Landry et al. (1995) calculated that mesozooplankton $(>200 \mu \mathrm{m})$ grazing in the Southern California Bight seasonally accounted for 16 to $44 \%$ of phytoplankton growth but that only 23 to $32 \%$ of this grazing was lost rapidly enough from the euphotic zone to be recovered as fecal pellets in sediment traps down to $100 \mathrm{~m}$. Zeldis (2001) concluded that $<4 \%$ of the POC in sediment traps was due to copepod fecal pellets during an iron enrichment experiment in the Southern Ocean.

The relative contribution of zooplankton fecal pellets to vertical carbon flux can depend on the depth interval being considered. In the euphotic zone of an oligotrophic oceanic station in the sub-tropical North Pacific, there was a 2-layered system (Small et al. 1987) where, in the upper $40 \mathrm{~m}$, there was higher primary production, low chlorophyll concentration and low zooplankton biomass, and the zooplankton produced mainly small fecal pellets that were recycled. In the lower layer from 40 to $100 \mathrm{~m}$ depth, there was low primary productivity but high chlorophyll and zooplankton, and many larger zooplankton fecal pellets. There was no fecal pellet flux into sediment traps at $30 \mathrm{~m}$ but at $120 \mathrm{~m}$, fecal pellet flux was $30 \%$ of total carbon flux. Small et al. (1987) concluded that zooplankton fecal pellets are coupled more to carbon flux out of the bottom layers of oligotrophic euphotic zones than to the carbon flux of unlayered eutrophic euphotic zones. In contrast, Altabet (1989a) concluded that in the Sargasso Sea, the recycling of nutrients in the upper half of the euphotic zone was less efficient than that in the euphotic zone as a whole.

The relative contribution of fecal pellets to vertical flux also depends on epipelagic community structure. Michaels \& Silver (1988) simulated the size distribu- tions of pelagic producers and trophic positions of consumers, and their effects on the composition and amounts of sinking fluxes. Picoplankton were the dominant producers in the model, but they contributed little to downward fluxes due to the large number of trophic steps between picoplankton and producers of fecal pellets. Net phytoplankton, though less abundant than smaller phytoplankton, were important contributors to the vertical flux because of the comparatively few trophic steps between them and their consumers, which produce large sinking fecal pellets, and because blooms of netplankton can sink to the benthos directly. The vertical flux varied strongly with community composition of consumers producing fecal pellets. Generalist grazers, which ingest a broad size spectrum of prey from pico- and nanoplankton, were major exporters of fecal pellets to depth. Such generalists that form swarms, including salps and doliolids, may have important episodic impacts on the overall average export from the epipelagic.

The contribution of fecal pellet carbon to total particulate carbon flux out of the euphotic zone can also vary with size and relative carnivorous versus herbivorous feeding patterns of the zooplankton community. Small \& Ellis (1992) found that the percentage of total carbon flux attributable to fecal pellet flux from larger zooplankton $(>500 \mu \mathrm{m})$ in the Santa Monica Basin off California also varied with season, from $10 \%$ in October to $172 \%$ in May. Assuming no carnivory and adding in fecal pellet flux from smaller (200 to $500 \mu \mathrm{m})$ zooplankton, much of which may have been recycled in the epipelagic, percentages of total carbon flux represented by fecal pellet flux ranged from $18 \%$ in January and February to $199 \%$ in May.

The relative contribution of fecal pellets to total particulate flux can vary in relation to El Niño conditions (González et al. 2000a,b). In January 1997, prior to the 1997-1998 El Niño in the northern Humboldt Current off Chile, zooplankton fecal pellets accounted for means of 5 to $10 \%$ of the total POC in sediment traps over the upper $300 \mathrm{~m}$ depth. This was during a period when the zooplankton assemblage was dominated by copepods. In July 1997, during the onset of El Niño, the deepening of the thermocline led to a reduction of nutrient input by upwelling, and chlorophyll levels were low. The zooplankton during this period included abundant salps and euphausiids, and zooplankton feces, primarily fecal strings of euphausiids, accounted for means of 24 to $38 \%$ of total sedimenttrap POC. In post-El Niño conditions in January 1998, when copepods were again dominant, zooplankton fecal pellet carbon had declined to 2.7 to $11.3 \%$ of total sediment-trap carbon.

The relative contributions of zooplankton fecal pellets compared to ungrazed phytoplankton can also 
vary in relation to upwelling seasons and copepod life cycles. Smith (2001) concluded that zooplankton grazing in the Arabian Sea could control vertical flux variations. During June at the onset of upwelling, large copepods in the epipelagic grazed extensively on diatoms, preventing diatom blooms. The largest vertical flux events were recorded near the end of the upwelling season in August and September, after the dominant copepods had migrated to depth to begin diapause, when ungrazed diatoms constituted the dominant component of sediment-trap contents (Passow et al. 1993).

The apparent importance of fecal pellet flux to depth may also depend on benthic conditions. Pilskaln (1991) found that zooplankton fecal pellets were extremely abundant in anoxic surface sediments of the Black Sea. These fecal pellets were packed with coccolithophorid remains and contributed substantially to the white coccolith-rich sediments. Pilskaln concluded that abundant fecal pellets in these anoxic sediments substantiated the claim that the widespread lack of fecal pellets in sediments deposited under aerobic conditions was due to remineralization by benthic microbes and consumers.

Part of the variability in estimates of the importance of fecal pellets in sedimentary flux may be due to patchiness of fecal pellets and the animals producing them. Using a submersible, Youngbluth et al. (1989) observed abundant fecal pellets (50 to $325 \mathrm{~m}^{-3}$ ) in situ in the Gulf of Maine and canyons south of Georges Bank, where pellets were accumulated at night in 5 to $24 \mathrm{~m}$ thick layers in the pycnocline. Positions of these layers in the water column varied with time of day. The pellets were produced by the vertically migrating euphausiids Meganyctiphanes norvegica, which were present in enormous aggregations (up to $10^{4} \mathrm{~m}^{-3}$ ), usually near the seabed. These pellets sank rapidly (means of 200 to $211 \pm 32 \mathrm{~m} \mathrm{~d}^{-1}$ ) and were estimated to transport large amounts of organic matter (means of 7 to $12 \mathrm{mg} \mathrm{C} \mathrm{m}^{-2} \mathrm{~d}^{-1}$ ) to the bottom. Youngbluth et al. (1989) concluded that amounts of vertical flux due to zooplankton fecal pellets can vary considerably with hydrography and zooplankton behavior.

\section{MARINE SNOW}

'When I think of the floor of the deep sea...I see always the steady, unremitting, downward drift of materials from above, flake upon flake, layer upon layer...the most stupendous "snowfall" the earth has ever seen.'

Rachael Carson (1951) p. 74

'Marine snow' refers to organic aggregates $>500 \mu \mathrm{m}$ in size (Alldredge \& Silver 1988). Such aggregates are abundant and ubiquitous in the ocean, and comprise many types of particles, originating from a variety of sources. As reviewed by Alldredge \& Silver (1988), the study of marine snow began with in situ observations and collections from submersibles, primarily by Japanese researchers beginning in the 1950s (Tsujita 1952, Suzuki \& Kato 1953, Nishizawa et al. 1954, Inoue et al. 1955, Nishizawa 1966, 1969, Kajihara 1971). Field studies by primarily North American scientists in the 1960s and 1970s focused on samples named 'organic aggregates' collected from water bottles (Riley 1963, 1970, Johannes 1967, Gordon 1970, Wiebe \& Pomeroy 1972, Wangersky 1974). Other studies, primarily in the laboratory, addressed the role of bubbles, turbulence and bacteria in the conversion of dissolved organic material to particulate organics (Baylor et al. 1962, Sutcliffe et al. 1963, Menzel 1966, Sheldon et al. 1967, Batoosingh et al. 1969, Johnson 1976, Johnson \& Cooke 1980, Kranck \& Milligan 1980, Biddanda 1985), and whether such particles supported nutrition of filter-feeding animals (Baylor \& Sutcliffe 1963). Since the late 1970 s and 1980 s, there has been a coalescence of in situ study using SCUBA and submersibles (Silver et al. 1978, Trent et al. 1978) with laboratory and shipboard field studies (reviewed below).

Marine snow and other macroscopic organic aggregates may originate from a variety of sources. These include abandoned larvacean houses, diatom and dinoflagellate flocs, fecal aggregates and aggregates of miscellaneous detritus (Alldredge \& Gotschalk 1990, Alldredge et al. 1998). Marine snow particles contain sticky microbially produced exopolymers that have high efficiencies of aggregation (Alldredge \& McGillivary 1991, Stolzenbach 1993, Stolzenbach \& Elimelech 1994). Large marine snow macroflocs form under conditions of high phytoplankton biomass and low wind speeds, and dissipate with wind-induced turbulence (Riebesell 1992). Marine snow also accumulates at water-column density discontinuities (MacIntyre et al. 1995).

Marine snow becomes enriched by a variety of attached planktonic organisms and other particles. These include bacteria, photosynthetic picoplankton, diatoms, diatom resting spores, dinoflagellates, other primary producers, protozoans, small detrital particles, minerals and fecal pellets (Silver et al. 1978, 1998a, Trent et al. 1978, Silver \& Alldredge 1981, Knauer et al. 1982, Prézelin \& Alldredge 1983, Biddanda 1985, 1986, 1988, Alldredge et al. 1986, 1998, Beers et al. 1986, Caron et al. 1986, Davoll \& Silver 1986, Silver et al. 1986, Taylor et al. 1986, Amy et al. 1987, Eisma 1987, Biddanda \& Pomeroy 1988, Herndl 1988, Herndl \& Peduzzi 1988, Davoll \& Youngbluth 1990, Simon et al. 1990, Turley 1991, Bochdansky \& Herndl 1992a,b, Kaltenböck \& Herndl 1992, Müller-Niklas \& Herndl 1992, Smith et al. 1992, Buck \& Chavez 1994, Kilps et 
al. 1994, Steinberg et al. 1994, Turley \& Mackie 1994, Artolozaga et al. 1997, Holloway \& Cowen 1997, Leppard et al. 1997, Noji et al. 1997, Rath et al. 1998, Ploug \& Grossart 2000). Various zooplankters also appear to be associated with marine snow (Alldredge 1972, 1976, Shanks \& Edmonson 1990, Steinberg et al. 1994, 1997, Walters \& Shanks 1996, Green \& Dagg 1997, Shanks \& del Carmen 1997, Shanks \& Walters 1997, Kiørboe 2000).

Marine snow aggregates provide small-scale patchiness of larger particles that may be nutritionally enhanced parcels when consumed by larger pelagic organisms. Microscale chemical patches of oxygen and $\mathrm{pH}$ around marine snow particles and fecal pellets were confirmed by Alldredge \& Cohen (1987). Ploug et al. (1999) found that marine snow aggregates were net heterotrophic communities that were hotspots of microbial respiration in the water column. Alldredge (2000) found that dissolved organic carbon associated with marine snow can be up to $31 \%$ of the total organic carbon in aggregates and suggested that previous measurements of sedimenting carbon that only included particulate carbon may have underestimated the total vertical flux of organic carbon.

Macroscopic aggregates (>1 $\mathrm{mm}$ ) are abundant in epipelagic as well as mesopelagic and bathypelagic waters (Silver \& Alldredge 1981, Honjo et al. 1984, Davoll \& Youngbluth 1990, Gardner \& Walsh 1990, Pilskaln et al. 1998, Silver et al. 1998b). In Monterey Bay, California, phytoplankton-containing aggregates constituted about half the aggregates in the upper 40 to $250 \mathrm{~m}$ layers but declined to only $5 \%$ of aggregates at $400 \mathrm{~m}$, prompting Silver et al. (1998b) to suggest that many sub-euphotic zone aggregates were derived from sources not tied to phytoplankton production cycles.

Aggregates are resistant to disaggregation (Alldredge et al. 1990) and are typically chemically enriched with higher concentrations of organic carbon, nitrogen, protein, carbohydrate, lipid, phaeopigments, chlorophyll and particulate weight than of those in the surrounding water column (Alldredge 1979, 1998), as well as with high levels of trace metals (Hebel et al. 1986).

Concentrations of attached bacteria, phytoplankton and heterotrophic protozoan cells (many of which appear alive), zooplankton, fecal pellets, other biogenic debris, and organic carbon on marine snow and other large particles can exceed those suspended in the surrounding water by as much as 2 to 4 orders of magnitude (Fellows et al. 1981, Silver \& Alldredge 1981, Caron et al. 1982, Bochdansky \& Herndl 1992a,b, Lampitt et al. 1993b, Steinberg et al. 1994, Turley \& Mackie 1994, Ploug et al. 1999, Waite et al. 2000). Levels of primary productivity and chlorophyll of algae attached to marine snow can exceed those of the sur- rounding water column by up to 2 orders of magnitude (Alldredge \& Cox 1982), but only marine snow of phytoplankton origin contributes significantly to primary production in surface waters (Alldredge \& Gotschalk 1990). For marine snow in the mesopelagic zone, however, even though bacteria attached to marine snow were $>100$ times more abundant than in surrounding seawater, since marine snow was rare ( 0.4 to 5.0 aggregates $\left.\mathrm{m}^{-3}\right)$, the contribution made by bacteria attached to marine snow to total mesopelagic zone bacterial production was insignificant, ranging from 0.01 to $0.39 \%$ (Alldredge \& Youngbluth 1985). Plumes of dissolved organics leaking from sinking aggregates may attract bacteria from the water column to attach to marine snow (Kiørboe \& Jackson 2001). There are also suggestions that bacteria attached to marine snow and other organic aggregates appear to be taxonomically different from those dominating water-column assemblages (DeLong et al. 1993).

Marine snow and other sinking particles may contain enhanced levels of viruses (Proctor \& Fuhrman 1991). Large virus-like particles have been found in bulk sediment-trap material, in zooplankton guts and fecal pellets, and in phaeodarian radiolarians, which may have acquired viruses while feeding on sinking or suspended particulates (Gowing 1993).

Depending on their sizes, shapes and densities, marine snow particles may sink tens to hundreds of meters per day, which is either faster or slower than many types of zooplankton fecal pellets (Shanks \& Trent 1980, Silver \& Alldredge 1981, Taguchi 1982b, Gorsky et al. 1984, Asper 1987, Alldredge \& Gotschalk 1988, Diercks \& Asper 1997). Since marine snow particles 'scavenge' smaller particles including fecal pellets from the surrounding water as they sink (Hill \& Nowell 1990), adherence to marine snow particles may either enhance or retard sinking rates of fecal pellets (Alldredge 1979). A model by Jackson (2001) suggests that sinking rates of marine snow particles may be enhanced if high-density fecal pellets become embedded in the marine snow. Rapidly sinking mucous aggregates from web-feeding euthecosomatous pteropods scavenge picoplankton-sized particles, thereby greatly accelerating their sinking rates (Noji et al. 1997), and Waite et al. (2000) observed massive sedimentation of picoplankton embedded in organic aggregates in the South Pacific.

Some forms of marine snow are fecal pellets. Pomeroy \& Deibel (1980) found that up to $4 \mathrm{~d}$ old fecal ribbons from pelagic tunicates (salps and doliolids) resembled the flocculent organic aggregates colonized with microorganisms that are typically described as 'marine snow' in productive parts of the ocean. Older particles of feces resembled the uncolonized aggregates that appear to be ubiquitous throughout the 
ocean. There was a microbial succession on fresh aggregates that initially contained phytoplankton remains but that subsequently developed populations of larger bacteria cells and later protozoans such as flagellates and ciliates. The microbial populations appeared to originate both from cells contained in the feces and from others colonizing from the surrounding water column. However, most bacteria cells in the feces were larger 1 to $3 \mu \mathrm{m}$ rods and cocci, which were different from the $<1 \mu \mathrm{m}$ minibacteria in the seawater.

Marine snow is a food source for pelagic organisms. Lampitt et al. (1993a) found that marine snow particles in the northeast Atlantic exhibited diel variability in abundance and depth, and suggested that this was due to ingestion by vertically migrating mesopelagic fauna. Lampitt et al. (1993b) confirmed from both gut contents produced on natural diets and feeding experiments conducted at sea that several species of ostracods, copepods and the micronektonic amphipod Themisto compressa consumed marine snow. This implied that a food-web shortcut by which picoplankters attached to marine snow, which are too small to be efficiently consumed by mesozooplankton and micronekton, can become part of the diets of these upper-trophic-level consumers when they eat marine snow. Amphipod fecal pellets contained such picoplankters, and gut passage times for vertically migratory amphipods were long enough to allow marine snow consumed at night in the epipelagic to be eliminated at mesopelagic daytime depths. Lampitt et al. (1993b) calculated that such 'gut flux' for the amphipod population might constitute as much as $2 \%$ of the vertical flux measured simultaneously in sediment traps. Dagg (1993) suggested from both energy-budget imbalances and gut contents that the large ( 7 to $9 \mathrm{~mm}$ long) copepod Neocalanus cristatus in the sub-Arctic Pacific must be ingesting large detrital particles such as marine snow. There are other reports or suggestions that zooplankton ingest various types of marine snow, mainly originating from planktonic tunicates (Alldredge 1972, 1976, Hamner et al. 1975, Alldredge \& Madin 1982, Ohtsuka \& Kubo 1991). Also, Lawrence et al. (1993) found that copepods ingested and assimilated bacteria attached to detrital particles such as marine snow, again suggesting a shortcut between the microbial loop and the grazing food chain. Laboratory investigations have confirmed that marine snow is consumed by copepods and euphausiids (Bochdansky \& Herndl 1992a, Dilling et al. 1998), and fish (Larson \& Shanks 1996). Graham et al. (2000) attributed a nighttime reduction in amounts of marine snow in near-surface waters off California to consumption or disruption by euphausiids and large copepods that had migrated upward into the epipelagic. Indeed, Dilling \& Alldredge (2000) and Goldthwait et al. (2001) found that euphausiids caused fragmentation of marine snow particles by the activity of swimming.

A particular type of macroscopic aggregate is the mucilage phenomenon in the Adriatic Sea (reviewed by Stachowitsch et al. 1990, Herndl 1992). These events have been known for centuries and can cause beach fouling on a massive scale (mare sporco or 'dirty sea' in Italian), and benthic anoxia. The mucilagenous accumulations are thought to be initially produced by diatoms (Heissenberger et al. 1996, Leppard et al. 1996, Najdek 1996). The intermittent timing and interannual variability of mucilage outbreaks makes pinpointing a cause difficult.

Alldredge et al. (1993) and Kiørboe \& Hansen (1993) described previously unknown forms of organic aggregates in the sea known as transparent exopolymer particles (TEP). TEP are small, transparent and extremely abundant, and are formed from dissolved exopolymers exuded by phytoplankton and bacteria. TEP range in the longest dimension from 3 to hundreds of micrometers, and in abundance from 28 to $500 \mathrm{ml}^{-1}$ in coastal California waters. TEP are sticky (B. E. Logan et al. 1995), have high levels of attached bacteria, and are major agents in the aggregation of diatoms and in the formation of marine snow. Alldredge et al. (1993) suggested that TEP might transform dissolved organic matter into particulates by a rapid abiotic pathway, in addition to remineralization by microbes. The abundance, size and extent of bacterial colonization of TEP are quite variable (Passow \& Alldredge 1994, Mari \& Kiørboe 1996), and TEP can be important in the flocculation and mass sinking of diatom blooms (Passow et al. 1994, Alldredge et al. 1995, Passow \& Alldredge 1995, Waite et al. 1997, Ploug \& Jørgensen 1999, Ramaiah et al. 2001) and blooms of Phaeocystis spp. (Hong et al. 1997). However, Engel \& Schartau (1999) found that diatom aggregates without TEP sank faster than those with TEP, because TEP reduced the density of aggregates. TEP appear to form from dissolved precursor material (Passow 2000), and phytoplankton appear to be the most important source of TEP, although bacteria may possibly enhance phytoplankton production of TEP (Passow et al. 2001). Schuster \& Herndl (1995) concluded that turbulence was more important than bacteria in the water column in the formation of TEP particles in the Adriatic. Krembs \& Engel (2001) found that TEP were abundant in Arctic sea ice. Colloidal TEP can be eaten by protozoans (Shimeta 1993, Tranvik et al. 1993) and larvaceans (Flood et al. 1992). Passow \& Alldredge (1999) showed that TEP-nanoplankton clusters were readily grazed by euphausiids, and that this process shortcircuited the microbial loop by making cells normally too small to be efficiently grazed available to euphausiids after incorporation into TEP clusters. 
Long \& Azam (1996) found abundant proteinaceous fibrous particles in the sea that were 3 to 13 times more abundant than TEP, with up to 2 orders of magnitude greater area. Bacteria had colonized 20 to $40 \%$ of these particles. Long \& Azam (1996) suggested that these proteinaceous particles may serve as nitrogen sources for bacteria and other organisms.

An important summary of both theoretical and empirical studies in the emerging fields of TEP, and the roles of aggregation and stickiness of phytoplankton and other particles in vertical flux was presented in a special issue of 'Deep-Sea Research' (Part II, Vol. 42, No. 1) entitled 'Aggregation in marine systems' (Alldredge \& Jackson 1995, and papers referenced therein).

\section{PHYTOPLANKTON SEDIMENTATION}

\begin{abstract}
'...Huxley was certainly wrong in his interpretation of [Bathybius haeckeli] as a new and primitive life form, but his error was not quite so foolish as many of his contemporaries and subsequent commentators have suggested. Perhaps later generations of oceanographers are much more open to criticism for not recognizing a phenomenon of such potential significance [i.e., sedimented phytoplankton blooms] for so long!'
\end{abstract}

$$
\text { Rice (1983) p. } 179
$$

Phytoplankton were not considered to be a major component of the sedimentary flux until recently. This was because laboratory studies of sinking rates of phytoplankton cells gave sinking rates typically $<1$ to tens of $\mathrm{m} \mathrm{d}^{-1}$ (Smayda 1970, 1971, Smayda \& Bienfang 1983, and references therein). However, field studies over the last 2 decades revealed that some ungrazed phytoplankton blooms can sink directly to the benthos at unexpectedly rapid rates.

Bloom sedimentation was first shown for shallow coastal waters (20 m depth) of Kiel Bight (Smetacek et al. 1978, 1984, Smetacek \& Hendrikson 1979, Smetacek 1980a,b, 1984). Peaks in phytoplankton sedimentation occurred during the spring diatom bloom in March and April. The low C:chl a ratios of sedimented materials indicated that it was primarily fresh phytoplankton. Phytoplankton sedimentation declined from May through August during a period when the phytoplankton was dominated by dinoflagellates and microflagellates, and zooplankton were abundant. The high $\mathrm{C}: \mathrm{chl} a$ and $\mathrm{C}: \mathrm{N}$ ratios of sedimented materials during summer indicated that it was highly degraded, due to decomposition under warmer temperatures or zooplankton grazing, or both. Sedimentation increased again during fall diatom and dinoflagellate blooms, when low C:chl a ratios again indicated that sedimented material was primarily phytoplankton instead of detritus. The highest rates of sedimentation were during winter, when most material collected in sediment traps was resuspended bottom sediments, with high C:chl a ratios, that had been mixed into the water column by turbulence from frequent storms.

There are other recent reports of episodic mass sedimentation of phytoplankton blooms in coastal waters. Bodungen et al. (1981) similarly reported that a spring bloom in the Baltic, comprising mainly the diatom Skeletonema costatum, sank to the benthos. This occurred under calm sea conditions, prior to seasonal thermal stratification. Calculated sinking rates for the S. costatum bloom were 30 to $50 \mathrm{~m} \mathrm{~d}^{-1}$. Cadée (1985) found that macroaggregates with intact cells of the coccolithophorid Emiliana huxleyi embedded in mucoid materials were collected in floating sediment traps in the epipelagic, but below the euphotic zone (40 to $70 \mathrm{~m}$ depth), during a spring bloom in the North Sea, just after the maximum abundance of this coccolithophorid in the surface layer. Sedimentation of seasonal blooms has also been observed in other nearshore waters off northern Europe (Peinert et al. 1982, Davies \& Payne 1984, Cadée 1986, Nicolaisen \& Christensen 1986, Noji et al. 1986, Peinert 1986, Skjoldal \& Wassmann 1986, Rey \& Skjoldal 1987, Kempe \& Jennerjahn 1988, Lutter et al. 1989, Wassmann et al. 1991, Passow \& Wassmann 1994, Trimmer et al. 1999, Reigstad et al. 2000, Olesen 2001), the Canadian Arctic (Atkinson \& Wacasey 1987, Hsiao 1987, Tremblay et al. 1989, Riebesell 1993), British Columbia (Sancetta \& Calvert 1988, Sancetta 1989a), California (Alldredge \& Gotschalk 1989, Gotschalk \& Alldredge 1989, Logan \& Alldredge 1989), Washington (Kiørboe et al. 1996), Alaska (Laws et al. 1988, Hansell et al. 1989, Waite et al. 1992), Narragansett Bay (Riebesell 1989) and Antarctica (Bathmann et al. 1991, Karl et al. 1991, Leventer 1991, Rutgers van der Loeff \& Berger 1991, Gowing et al. 2001). Walsh (1983) has speculated that mass sedimentation of phytoplankton blooms to continental shelf sediments may represent substantial global sinks of carbon and nitrogen, and a simulation by Boyd \& Newton (1999) suggests that sinking of large ungrazed phytoplankton cells, probably diatoms, may be a major determinant of the flux of particulate organics in several ocean habitats.

Smetacek (1985) has argued that rapid mass sinking of diatom blooms may be a transition from growing to resting stages in the life histories of these algae. Smetacek suggested that sinking is of survival value in diatom species that survive long periods in cold and dark, but not warm nutrient-depleted surface waters. Formation of mucous diatom flocs would accelerate sinking rates of diatoms to depth, away from surface strata with high population levels of zooplankton, during or immediately prior to seasons of maximum grazing pressure. Smetacek (1985) also suggested that 
diatom sinking may 'seed' coastal sediments with diatom resting spores, contributing to persistence of diatom species in an area by providing seed populations for the next growing season. Bodungen et al. (1986) found evidence for such a scenario in the Antarctic Peninsula region. Formation of diatom aggregates has also been shown to enhance sedimentation in the North Sea (Riebesell 1991a,b) and in the Antarctic (Riebesell et al. 1991).

Mass sedimentation of diatoms appears to have been occurring for tens of thousands to millions of years. Jordan et al. (1991) invoked flocculation as a mechanism explaining a $3 \mathrm{~cm}$ thick layer of well-preserved diatom sediments from the upper Pleistocene in the Antarctic. Sancetta et al. (1992) summarized data on sinking of rhizosolenid diatoms and concluded that this is a common occurrence now, as well as in the past (Sancetta 1993). Schubert et al. (1998) used organic chemical biomarkers in sediments to reveal that the relative proportions of diatoms and dinoflagellates remained similar but that combined phytoplankton abundances tracked changes in ocean productivity in the Arabian Sea over the last 200000 yr.

Sapropels (sediment layers with high concentrations of organic carbon) from the Pliocene to the Pleistocene age (5 million to $10000 \mathrm{yr}$ old) from the eastern Mediterranean are composed primarily of rhizosolenid diatoms (Kemp et al. 1999, Sancetta 1999). These appear to have formed dense mats during summer, which would be expected to be an oligotrophic period. However, such diatoms have endosymbiotic nitrogenfixing cyanobacteria, which might have enabled them to survive during stratified nitrogen-depleted conditions. Mass sedimentation of these diatoms appears to have contributed to the widespread coincident hypoxia or anoxia recorded in these sediments.

Seasonal mass sedimentation of large diatoms is still a major feature in modern seas (Kemp et al. 2000, Smetacek 2000, Trull \& Armand 2001). Examination of laminated sediments and diatom fluxes from sediment traps from the Gulf of California and the Mediterranean led Kemp et al. (2000) to propose that where there is a strong seasonal thermocline and nutricline, several taxa of 'giant' (>50 $\mu \mathrm{m}$ in longest dimension) diatoms may be able to generate substantial production at depth during the summer. Included would be several species of the genera Rhizosolenia, other rhizosolenids such as Proboscia and Pseudosolenia, and species of Stephanopyxis, Thalassiothrix and Coscinodiscus. Some large diatoms such as these appear to be adapted to low light (Goldman 1993) and able to vertically migrate between the euphotic zone and nutrientrich deeper layers by controlling buoyancy (Villareal et al. 1993, 1996, 1999). Their large size and robust thecae may also make them harder for grazers to eat; thus, they may live longer, allowing a biomass buildup (Smetacek 2000). If these giant diatoms persist at depth throughout the stratified summer period, autumn mixing may cause a 'fall dump' of these diatoms, which can produce as much, if not more, export production of diatoms as the typical spring bloom. This might prompt re-evaluation of the common assumption that diatomaceous sediments are paleontological evidence of upwelling because they might have been deposited under oligotrophic conditions instead.

Kiørboe et al. (1998) found that diatom aggregates in the Benguela Current upwelling were extremely sticky and contributed little to vertical flux. This was because aggregates became colonized by the heterotrophic dinoflagellate Noctiluca scintillans (Tiselius \& Kiørboe 1998), which not only grazed on the diatom aggregates but also imparted buoyancy to them so that they did not sink.

Svensen et al. (2001) tested the hypotheses that increased levels of silicate would favor diatom growth, with consequent increases in sedimentation, and that increased turbulence would increase diatom sedimentation through increased aggregation. Neither hypothesis was upheld. While increased silicate did enhance diatom growth, this did not increase phytoplankton sedimentation, relative to communities dominated by flagellates, and increased turbulence had no effects on sedimentation of diatom- versus flagellate-dominated assemblages.

There can be a rapid benthic response to organic input from sinking phytoplankton blooms in shallow water. Graf et al. $(1982,1984)$ found that there was immediate stimulation of benthic microbial activity following sedimentation of a spring phytoplankton bloom in Kiel Bight. The bivalve Macoma baltica, a macrobenthic sediment surface feeder, commenced accumulation of lipid and glycogen reserves immediately following bloom sedimentation. Responses of other macrobenthic animals were less clear. It appeared that the organic material contributed by this bloom was remineralized within 2 to $3 \mathrm{wk}$, so its overall contribution to the annual benthic energy budget was only 15 to $25 \%$. During sedimentation of subsequent phytoplankton blooms in Kiel Bight, Graf et al. (1983) found that an autumn phytoplankton bloom was not consumed rapidly by microbial processes, but a spring bloom was consumed within 5 to $6 \mathrm{wk}$. A simulation of the responses to the fall bloom agreed with field observations (Graf 1987). Supply of food from the surface layer to the benthos, as deduced from sediment samples, appears to be an important factor affecting macrobenthic community structure, biomass and metabolism on the continental shelf in the Bering and Chukchi Seas (Graebmeier et al. 1988, 1989, Graebmeier \& McRoy 1989). Meiofauna gave varied re- 
sponses to sedimenting phytodetritus, in that it was extensively ingested by harpacticoid copepods but not by other meiofauna (Rudnick 1989) or that there were no apparent relationships between interannual variations in meiofaunal abundance and supply of sedimenting phytodetritus in Auke Bay, Alaska (Fleeger et al. 1989). In the Cretan Sea (northeast Mediterranean), seasonal deposition of phytodetritus stimulated benthic responses by bacteria (Danovaro et al. 2000c) and meiofauna (Danovaro et al. 2000a). Deposition from phytoplankton blooms can also alter sediment nutrient regimes (Conley \& Johnstone 1995) and production of dimethylsulfide (DMS) (Osinga et al. 1996).

Phytoplankton blooms can also sink directly into deep water (reviewed by Rice et al. 1986). Deuser \& Ross (1980) and Deuser et al. (1981a) found that the flux of organic carbon and particles to the deep (3200 m) Sargasso Sea near Bermuda appeared closely tied to the annual cycle of phytoplankton primary production in surface waters. This signal persisted despite interannual variations (Deuser 1986, 1987, Deuser et al. 1990, 1995). This suggested that there was an efficient mechanism for rapid export $(<60 \mathrm{~d})$ of even fine particles from the surface to abyssal depths.

Billett et al. (1983) confirmed the rapid seasonal sedimentation of intact phytoplankton cells to depths of 1 to $4 \mathrm{~km}$ in the deep sea off Scotland. Phytoplankton was part of an amorphous organic matrix of fluffy detritus, which time-lapse photography revealed arrived on the sea floor within time intervals of a few hours during the spring-summer bloom period of April to July. Surface sediment samples revealed that the detrital matrix contained intact phytoplankton assemblages resembling those of spring and summer blooms in the overlying near-surface waters during periods immediately prior to sedimentation events. Spring blooms were dominated by diatoms, whereas summer blooms contained proportionately more coccolithophorids. Such rapid sedimentation implied sinking to depths of $2000 \mathrm{~m}$ over periods of as little as 2 to $3 \mathrm{wk}$, or sinking rates of 100 to $150 \mathrm{~m} \mathrm{~d}^{-1}$. Incorporation of phytoplankton cells into fecal pellets may help explain the rapid descent in summer but not in the early spring, when zooplankton abundance was low, and fecal pellets were scarce in the settled detritus. It was suggested that incorporation of phytoplankton cells into gelatinous matrices enhanced sedimentation rates. Lampitt (1985) showed in subsequent years that the phytoplankton sedimentation recorded by Billett et al. (1983) was not an isolated incident but rather a regular summer occurrence, and extended the recorded depth of this phenomenon from $2000 \mathrm{~m}$ to $4000 \mathrm{~m}$. Phytodetrital aggregates sinking from surface layers to $4500 \mathrm{~m}$ in the North Atlantic contained a rich community of active bacteria and cyanobacteria
(Turley \& Mackie 1995), which rapidly degraded and transformed the sedimented material in the deep sea (Lochte \& Turley 1988, Pfannkuche 1993), as well as phaeodarian radiolarians and their fecal pellets (Riemann 1989). The formation of phytoplankton aggregates relates partly to coagulation efficiency ('stickiness'), which increases when cell growth decreases and nutrient limitation increases (Kiørboe et al. 1990). Such phytodetrital material is also utilized as food by a wide variety of benthic animals (Thiel et al. 1988) and benthic foraminifera (Gooday 1988). Widespread and abundant phytodetrital aggregates have also been photographed on the sea floor between 450 and $2400 \mathrm{~m}$ after the spring bloom on the continental slope of the northwestern Atlantic (Hecker 1990).

Similar linkages between seasonality of surface productivity patterns and vertical flux to the deep sea have been recorded for many areas. These include the Panama Basin (Honjo 1982), the Black Sea (Hay et al. 1990), the Arabian Sea (Haake et al. 1993), the Antarctic (Wefer et al. 1990, DiTullio et al. 2000), the North Pacific (Scharek et al. 1999), the North Atlantic (Honjo \& Manganini 1993, Passow \& Peinert 1993, Pfannkuche 1993), the Cretan Sea (Danovaro et al. 2000a) and the Barents Sea (Wassmann 1989, Wassmann et al. 1990, 1994, Andreassen et al. 1996, Andreassen \& Wassmann 1998). Seasonally atypical transientepisodic vertical fluxes in the Sargasso Sea can also deliver labile phytoplankton-derived detritus not associated with the spring bloom to the deep Sargasso Sea to depths of $3400 \mathrm{~m}$ (Conte et al. 1998).

It has been suggested that mucoid agglomerations collected from the deep North Atlantic in 1857, which were described in 1868 by Thomas Henry Huxley as Bathybius haeckelli, may have actually been collections of settled detrital 'fluff' containing phytoplankton (Rehbock 1975, Rice 1983). The story is frequently repeated in introductory oceanography textbooks of how Huxley thought that $B$. haeckelli was a primordial life form, but his explanation was subsequently discredited during the circumglobal expedition of the HMS 'Challenger' (1872 to 1876), when it was concluded that $B$. haeckelli was nothing more than a precipitate caused when seawater samples were preserved in alcohol. Rice (1983) has shown, however, that in Huxley's descriptions of $B$. haeckelli, he noted inclusions that he called 'coccoliths', which had likely originated from coccolithophorids, although Huxley was unaware of this at the time. Subsequent drawings of $B$. haeckelli by Haeckel (reproduced by C. Wyville Thomson [1873], Fig. 63, presented in Rice 1983) show what are clearly coccoliths and coccolithophorids in the B. haeckelli matrix. Rice (1983) concluded that there is strong circumstantial evidence that the original samples of B. huxleyi collected in June and July of 
1857 in the northeast Atlantic may have been sedimented blooms of coccolithophorids in a gelatinous matrix, such as those described for the same area and season by Billett et al. (1983). There is increasing evidence of seasonal sedimentation of particulates to various locations in the deep sea (Deuser \& Ross 1980), including coccolithophorid blooms (Honjo 1982) and pine pollen (Hinga et al. 1979), which becomes incorporated into copepod fecal pellets (Turner 1991).

There are apparent deep-sea benthic responses to seasonality of phytoplankton and other particulate sedimentation (reviewed by Tyler 1988, Gooday \& Turley 1990). Tyler et al. $(1982,1990)$ found that annual reproductive periodicities and between-species synchrony in the reproductive cycles of several species of deep-sea echinoderms in the northeast Atlantic matched the productive cycle in the overlying surface waters. Echinoderm spawning occurred in late winter and early spring, coincident with the spring bloom. Witte (1996) found similar seasonal reproduction in deep-sea sponges coincident with episodic vertical flux. Lampitt (1990) presented photographic evidence for a single barnacle on the deep-sea floor that its growth rate over a period of $7 \mathrm{mo}$ was high and enhanced by the annual deposition of phytodetritus from the surface layer. Smith \& Baldwin (1984) found that sediment community oxygen consumption (SCOC) off California and Hawaii at depths of 3800 to $5900 \mathrm{~m}$ was seasonal, with the highest values in early summer, suggesting a benthic response to seasonality of surface productivity. Cole et al. (1987) found that of the organic carbon that sedimented to $3856 \mathrm{~m}$, comprising largely coccolithophorids and associated macroaggregates, 50 to $85 \%$ was remineralized within $1 \mathrm{yr}$, and the decomposition of these surface-derived particulates accounted for virtually all of the benthic decomposition at this site. Turley \& Lochte (1990) confirmed the potential for microbial processing of phytodetritus in laboratory experiments in which sterile detritus was incubated with deep-sea microbial communities under simulated abyssal conditions of high pressure and low temperature. Williams et al. (1987) used carbon isotopes to estimate that maximum estimates for turnover of organic carbon was 4 to $18 \mathrm{yr}$ in chronologically old bathy- and abyssopelagic fish and crustaceans from the North Pacific, and that rapid sinking of organic detritus from the surface was the primary source of organic carbon in the diets of these animals. Gooday \& Lambshead (1989) found that phytodetritus seasonally settled to the deep sea in the northeast Atlantic was a microhabitat for benthic foraminiferans, and that patchiness of phytodetritus caused patchiness and species distributions of foraminiferans. Graf (1989) found that a pulse of copepod fecal pellets to the deep-sea benthos in the Norwegian
Sea was utilized in $<8 \mathrm{~d}$ by burrowing infauna. A detrital layer on the bottom of the northeast Pacific was seasonally composed of diatoms in summer or radiolarians in fall (Beaulieu \& Smith 1998), but there was no significant correlation between distribution and abundance of deep-sea echinoderms and seafloor phytodetritus (Lauerman \& Kaufmann 1998). Pfannkuche et al. (1999) found that the benthic community response to sedimentation of a spring bloom in the North Atlantic included transient increases in metabolic activity but not in benthic biomass.

\section{Supply and demand of organic matter for the deep-sea benthos}

There have been several studies indicating that episodic input of organic matter to the deep-sea benthos appears to be an important aspect of supply and demand relationships. Comparisons of the supply of POC sedimenting to the floor of the North Pacific and SCOC, normalized to mineralization to $\mathrm{CO}_{2}$, indicated shortfalls of carbon supply in meeting sediment consumption demands of as much as $97 \%$ of mean values (Smith 1987, 1989). These results were based on short-term measurements (14 d) of sediment-trap accumulations of POC and measurements of SCOC with in situ benthic respirometers. However, in a long time series ( $>2 \mathrm{yr}$ ) of these measurements in the same area (Smith et al. 1992), when episodic input of POC was included in supply, there was agreement within $15 \%$ between organic carbon supply and demand. Smith et al. (1992) concluded that episodic inputs of organic matter can be critical for sustaining abyssal benthic communities below surface layers where seasonal inputs of primary production sediment to depth. In fact, Riebesell \& Wolf-Gladrow (1992) simulated particle flux due to phytoplankton bloom aggregation and found that particle flux to the deep ocean could be solely explained by this process. Smith et al. (1994) confirmed concurrence of increased SCOC with episodic seasonal input of POC, and time-lapse photography revealed that mobile epibenthic megafauna such as holothuroids and echinoids were twice as active when detrital aggregates reached the sea floor at $4100 \mathrm{~m}$ in spring as during other periods of the year.

Long-term time-series studies reveal that sedimentation patterns in the oligotrophic oceanic waters have seasonal, interannual and decadal components, as well as responses to major environmental perturbations such as upwelling or El Niño-Southern Oscillation events (Karl et al. 1996, Michaels \& Knap 1996, Pilskaln et al. 1996, Baldwin et al. 1998, Drazen et al. 1998, Lee et al. 1998, Smith \& Druffel 1998, Thunell 1998a, Hanson et al. 2000). The range of vertical 
flux, excluding highly variable polar regions, varies about 11-fold world-wide, and there is a general linear relationship between surface primary productivity and organic carbon flux to $2000 \mathrm{~m}$ (Lampitt \& Antia 1997). However, there are still major uncertainties regarding amounts of primary productivity exported by vertical flux and how these vary between locations, over time and with water-column food-web structure (Michaels et al. 1994a, Rivkin et al. 1996, Boyd \& Newton 1997, Doney 1997, Emerson et al. 1997, Hansell et al. 1997a, Karl et al. 1997, McGillicuddy \& Robinson 1997). Climate-induced domain shifts toward an ecosystem dominated by prokaryotes over the last 3 decades may be occurring in the North Pacific (Karl et al. 2001a), and this may have altered nutrient stoichiometry and flux pathways (Karl et al. 2001b) as well as export processes (Christian et al. 1997).

There is evidence, however, that at least some portions of the deep sea may be undergoing sustained reductions in the supply of organic matter supplied by vertical flux, and that these reductions may be related to processes in the overlying water column and atmosphere. A 7 yr time series of supply of POC sedimenting to the sea floor at $4100 \mathrm{~m}$ in the northeastern Pacific and SCOC revealed a pronounced decline in POC (52 to $59 \%$ ) without any significant reduction in SCOC from 1989 to 1996 (Smith \& Kaufmann 1999). This coincided with a period of increasing sea surface temperatures and declines in primary production, zooplankton biomass, kelp production and seabird abundance in the North Pacific (Druffel \& Robison 1999). Smith \& Kaufmann (1999) suggested that if these temperature increases are related to anthropogenic increases in greenhouse gases in the atmosphere, and if the decline in food supply to the deep sea is not reversed, concomitant shifts in the characteristics and composition of deep-sea benthic communities and the role of the ocean in the global carbon cycle could result. This apparent $7 \mathrm{yr}$ deficit was reversed in the eighth year, by an increase in sedimentary flux (Smith et al. 2001). What remains to be seen is whether much of the ocean bottom periodically experiences deficits of sedimented POC relative to SCOC. In the only other long-term study of these parameters, in the Sargasso Sea off Bermuda, SCOC appears relatively constant over time, and sedimented POC appears sufficient to balance it (Sayles et al. 1994). Smith et al. (2001) suggested that additional sources of organic matter undersampled by sediment traps, such as episodic lateral advection, terrestrial discharges or long-term climate variations in the oceanic production system, may be important in resolving discrepancies between organic matter supply and demand in the deep sea.

\section{SUMMARY}

The vertical flux in the sea is due to intertwined combinations of zooplankton and nekton fecal pellets, marine snow and phytoplankton detritus. Some fecal pellets attach to marine snow, some forms of marine snow are fecal pellets, and some phytoplankton detritus forms marine snow. Portions of this flux reach the benthos, but much, if not most, is repackaged or recycled in the water column. Synthesis of the relative contributions of fecal pellets, marine snow and sinking phytoplankton to vertical flux and water-column recycling is elusive, since these processes are highly variable, situation specific and dependent on multiple interacting factors. Within the last 2 decades a major discovery is that the deep sea is not as unvarying as earlier thought, but rather is subject to seasonal and episodic inputs of sedimenting organic matter, which may provoke benthic biological responses. Further, the sedimentary flux of fecal pellets, marine snow and phytodetritus is important not only to communities on the sea bottom but also to those in the water column. Together, fecal pellets, marine snow and sinking phytoplankton are major components of the 'biological pump' that not only transports and recycles materials in the sea but also may scrub greenhouse gases from the atmosphere.

Acknowledgements. I wish to thank Camilla Svensen of the University of Tromsø for an invitation to present an overview lecture at the 2001 Aquatic Sciences Meeting of the American Society of Limnology and Oceanography in Albuquerque, New Mexico, February 12 to 16, 2001, in a special session entitled: 'To sink or not to sink: the role of zooplankton for export and retention of fecal pellets and aggregates (environmental conditions).' That invitation prompted preparation of this review. Other presentations in that session, referenced in the 'Literature cited' dated (2001), include those of UrbanRich, Svensen \& Nejstgaard, Goldthwait et al., Olesen, Bauerfeind et al., Dam \& Feinberg, and Jackson. I greatly appreciate the assistance of Debbie Ellis of the University of Massachusetts at Dartmouth in preparing visuals for the Albuquerque presentation. I also thank John Dolan for editorial advice that improved the paper.

\section{LITERATURE CITED}

Abelmann A (1992a) Radiolarian flux in Antarctic waters (Drake Passage, Powell Basin, Bransfield Strait). Polar Biol 12:357-372

Abelmann A (1992b) Radiolarian taxa from Southern Ocean sediment traps (Atlantic sector). Polar Biol 12:373-385

Abelmann A, Gersonde R (1991) Biosiliceous particle flux in the Southern Ocean. Mar Chem 35:503-536

Agassiz A (1888) Three cruises of the United States Coast and Geodetic Survey steamer Blake in the Gulf of Mexico, in the Caribbean Sea, and along the Atlantic coast of the United States from 1877 to 1880, Vol 1. Bull Mus Comp Zool Harvard 14:1-314 
Alldredge AL (1972) Abandoned larvacean houses: a unique food source in the pelagic environment. Science 177: 885-887

Alldredge AL (1976) Discarded appendicularian houses as sources of food, surface habitats, and particulate organic matter in planktonic environments. Limnol Oceanogr 21: $14-23$

Alldredge AL (1979) The chemical composition of macroscopic aggregates in two neritic seas. Limnol Oceanogr 24: $855-866$

Alldredge A (1998) The carbon, nitrogen and mass content of marine snow as a function of aggregate size. Deep-Sea Res I 45:529-541

Alldredge AL (2000) Interstitial dissolved organic carbon (DOC) concentrations within sinking marine aggregates and their potential contribution to carbon flux. Limnol Oceanogr 45:1245-1253

Alldredge AL, Cohen Y (1987) Can microscale chemical patches persist in the sea? Microelectrode study of marine snow, fecal pellets. Science 235:689-691

Alldredge AL, Cox JL (1982) Primary productivity and chemical composition of marine snow in surface waters of the Southern California Bight. J Mar Res 40:517-527

Alldredge AL, Gotschalk CC (1988) In situ settling behavior of marine snow. Limnol Oceanogr 33:339-351

Alldredge AL, Gotschalk CC (1989) Direct observations of the mass flocculation of marine diatoms: characteristics, settling velocities and formation of diatom aggregates. DeepSea Res 36:159-171

Alldredge AL, Gotschalk CC (1990) The relative contribution of marine snow of different origins to biological processes in coastal waters. Cont Shelf Res 10:41-58

Alldredge AL, Jackson GA (eds) (1995) Aggregation in marine systems. Deep-Sea Res II 42:1-273

Alldredge AL, Madin LP (1982) Pelagic tunicates: unique herbivores in the marine plankton. BioScience 32:655-663

Alldredge AL, McGillivary P (1991) The attachment probabilities of marine snow and their implications for particle coagulation in the ocean. Deep-Sea Res 38:431-443

Alldredge AL, Silver MW (1988) Characteristics, dynamics and significance of marine snow. Prog Oceanogr 20:41-82

Alldredge AL, Youngbluth MJ (1985) The significance of macroscopic aggregates (marine snow) as sites for heterotrophic bacterial production in the mesopelagic zone of the subtropical Atlantic. Deep-Sea Res 32:1445-1456

Alldredge AL, Cole JJ, Caron DA (1986) Production of heterotrophic bacteria inhabiting macroscopic organic aggregates (marine snow) from surface waters. Limnol Oceanogr 31:68-78

Alldredge AL, Gotschalk CC, MacIntyre S (1987) Evidence for sustained residence of macrocrustacean fecal pellets in surface waters off Southern California. Deep-Sea Res 34: 1641-1652

Alldredge AL, Granata TC, Gotschalk CC, Dickey TD (1990) The physical strength of marine snow and its implications for particle disaggregation in the ocean. Limnol Oceanogr 35:1415-1428

Alldredge AL, Passow U, Logan BE (1993) The abundance and significance of a class of large, transparent organic particles in the ocean. Deep-Sea Res I 40:1131-1140

Alldredge AL, Gotschalk CC, Passow U, Riebesell U (1995) Mass aggregation of diatom blooms: insights from a mesocosm study. Deep-Sea Res II 42:9-27

Alldredge AL, Passow U, Haddock SHD (1998) The characteristics and transparent exopolymer particle (TEP) content of marine snow formed from thecate dinoflagellates. J Plankton Res 20:393-406
Alleman LY, Hamelin B, Véron AJ, Miquel JC, Heussner S (2000) Lead sources and transfer in the coastal Mediterranean: evidence from stable isotopes in marine particles. Dee-Sea Res II 47:2257-2279

Al-Mutairi H, Landry MR (2001) Active export of carbon and nitrogen at Station ALOHA by diel migrant zooplankton. Deep-Sea Res II 48:2083-2103

Altabet MA (1988) Variations in nitrogen isotopic composition between sinking and suspended particles: implications for nitrogen cycling and particle transformation in the open ocean. Deep-Sea Res 35:535-554

Altabet MA (1989a) A time-series study of the vertical structure of nitrogen and particle dynamics in the Sargasso Sea. Limnol Oceanogr 34:1185-1201

Altabet MA (1989b) Particulate new nitrogen fluxes in the Sargasso Sea. J Geophys Res 94:12,771-12,779

Altabet MA, Deuser WG (1985) Seasonal variations in natural abundance of ${ }^{15} \mathrm{~N}$ in particles sinking to the deep Sargasso Sea. Nature 315:218-219

Altabet MA, Small LF (1990) Nitrogen isotope ratios in fecal pellets produced by marine zooplankton. Geochim Cosmochim Acta 54:155-163

Altabet MA, Deuser WG, Honjo S, Stienen C (1991) Seasonal and depth-related changes in the source of sinking particles in the North Atlantic. Nature 354:136-139

Altabet MA, Pilskaln C, Thunell R, Pride C, Sigman D, Chavez F, Francois R (1999) The nitrogen isotope biogeochemistry of sinking particles from the margin of the eastern North Pacific. Deep-Sea Res I 46:655-679

Amy PS, Caldwell BA, Soeldner AH, Morita RY, Albright LJ (1987) Microbial activity and ultrastructure of mineralbased marine snow from Howe Sound, British Columbia. Can J Fish Aquat Sci 44:1135-1142

Anderson RF, Rowe GT, Kemp PF, Trumbore PF, Biscaye PE (1994) Carbon budget for the mid-slope depocenter of the Middle Atlantic Bight. Deep-Sea Res II 41:669-703

Anderson TR (1994) Relating C:N ratios in zooplankton food and faecal pellets using a biochemical method. J Exp Mar Biol Ecol 184:183-199

Andreassen IJ, Wassmann P (1998) Vertical flux of phytoplankton and particulate biogenic matter in the marginal ice zone of the Barents Sea in May 1993. Mar Ecol Prog Ser 178:1-14

Andreassen I, Nöthig EM, Wassmann P (1996) Vertical particle flux on the shelf off northern Spitsbergen, Norway. Mar Ecol Prog Ser 137:215-228

Andrews CC, Karl DM, Small LF, Fowler SW (1984) Metabolic activity and bioluminescence of oceanic faecal pellets and sediment trap particles. Nature 307:539-541

Andruleit HA (2000) Dissolution-affected coccolithophore fluxes in the central Greenland Sea (1994/1995). DeepSea Res II 47:1719-1742

Angel MV (1984) Detrital organic fluxes through pelagic ecosystems. In: Fasham MJR (ed) Flows of energy and materials in marine ecosystems: theory and practice. Plenum Press, New York, p 475-516

Angel MV (1989) Does mesopelagic biology affect the vertical flux? In: Berger WH, Smetacek VS, Wefer G (eds) Productivity of the ocean: present and past. John Wiley \& Sons, Chichester, p 155-173

Ansell AD (1974) Sedimentation of organic detritus in Lochs Etive and Ceran, Argyll, Scotland. Mar Biol 27:263-273

Antia AN, Bodungen BV, Peinert R (1999) Particle flux across the mid-European continental margin. Deep-Sea Res I 46: 1999-2024

Antia AN, Maaßen, Herman P, Voß M, Scholten J, Groom S, Miller P (2001) Spatial and temporal variability of particle 
flux at the N.W. European continental margin. Deep-Sea Res II 48:3083-3106

Artolozaga I, Santamaría E, López A, Ayo B, Iriberri J (1997) Succession of bacterivorous protists on laboratory-made marine snow. J Plankton Res 19:1429-1440

Asper VL (1987) Measuring the flux and sinking speed of marine snow aggregates. Deep-Sea Res 34:1-17

Asper VL, Smith WO Jr (1999) Particle fluxes during austral spring and summer in the southern Ross Sea (Antarctica). J Geophys Res 104(C3):5345-5359

Asper VL, Deuser WG, Knauer GA, Lohrenz SE (1992) Rapid coupling of sinking particle fluxes between surface and deep ocean waters. Nature 357:670-672

Atkinson EG, Wacasey JW (1987) Sedimentation in Arctic Canada: particulate organic carbon flux to a shallow marine benthic community in Frobisher Bay. Polar Biol 8:3-7

Ayukai T (1986) Rate of filtering of fecal pellets by Acartia omorii (Copepoda; Calanoida). J Oceanogr Soc Jpn 42: $487-489$

Ayukai T (1990) Fecal pellet production by two species of planktonic calanoid copepods fed on naturally occurring particles. Bull Plankton Soc Jpn 37:167-169

Ayukai T, Hattori H (1992) Production and downward flux of zooplankton fecal pellets in the anticyclonic gyre off Shikoku, Japan. Oceanol Acta 15:163-172

Ayukai T, Nishizawa S (1986) Defecation rate as a possible measure of ingestion rate of Calanus pacificus pacificus (Copepoda; Calanoida). Bull Plankton Soc Jpn 33:3-10

Azam F (1998) Microbial control of oceanic carbon flux: the plot thickens. Science 280:694-696

Bacon MP (1987) Oceanic flux of Chernobyl fallout. Nature 329:767-768

Bacon MP, Huh CA, Fleer AP, Deuser WG (1985) Seasonality in the flux of natural radionuclides and plutonium in the deep Sargasso Sea. Deep-Sea Res 32:273-286

Bacon MP, Cochran JK, Hirschberg D, Hammar TR, Fleer AP (1996) Export flux of carbon at the equator during the EqPac time-series cruises estimated from ${ }^{234} \mathrm{Th}$ measurements. Deep-Sea Res 43:1133-1154

Bailey TG, Robertson DR (1982) Organic and caloric levels of fish feces relative to its consumption by coprophagous reef fishes. Mar Biol 69:45-50

Baker ET, Feely RA, Landry MR, Lamb M (1985) Temporal variations in the concentration and settling flux of carbon and phytoplankton pigments in a deep fjordlike estuary. Est Coast Shelf Sci 21:859-877

Baker ET, Milburn HB, Tennant DA (1988) Field assessment of sediment trap efficiency under varying flow conditions. J Mar Res 46:573-592

Baldwin RJ, Glatts RC, Smith KL Jr (1998) Particulate matter fluxes into the benthic boundary layer at a long timeseries station in the abyssal NE pacific: composition and fluxes. Deep-Sea Res II 45:643-665

Banse K (1990) New views on the degradation and disposition of organic particles as collected by sediment traps in the open sea. Deep-Sea Res 37:1177-1195

Bathmann UV (1988) Mass occurrence of Salpa fusiformis in the spring of 1984 off Ireland: implications for sedimentation processes. Mar Biol 97:127-135

Bathmann UV (1996) Abiotic and biotic forcing on vertical particle flux in the Southern Ocean. In: Ittekkot V, Schäfer P, Honjo S, Depetris PJ (eds) Particle flux in the ocean. John Wiley \& Sons, Chichester, p 243-250

Bathmann UV, Liebezeit G (1986) Chlorophyll in copepod faecal pellets; changes in pellet numbers and pigment content during a declining Baltic spring bloom. PSZN I: Mar Ecol 7:59-73
Bathmann UV, Noji TT, Voss M, Peinert R (1987) Copepod fecal pellets: abundance, sedimentation and content at a permanent station in the Norwegian Sea in May/June 1986. Mar Ecol Prog Ser 38:45-51

Bathmann UV, Noji TT, Bodungen BV (1990a) Copepod grazing potential in late winter in the Norwegian Sea-a factor in the control of spring phytoplankton growth? Mar Ecol Prog Ser 60:225-233

Bathmann UV, Peinert R, Noji TT, Bodungen BV (1990b) Pelagic origin and fate of sedimenting particles in the Norwegian Sea. Prog Oceanogr 24:117-125

Bathmann U, Fischer G, Müller PJ, Gerdes D (1991) Shortterm variations in particulate matter sedimentation off Kapp Norvegia, Weddell Sea, Antarctica: relation to water mass advection, ice cover, plankton biomass and feeding activity. Polar Biol 11:185-195

Batoosingh E, Riley GA, Keshwar B (1969) An analysis of experimental methods for producing particulate organic matter in sea water by bubbling. Deep-Sea Res 16: 213-219

Bauerfeind E, Bodungen BV, Arndt K, Koeve W (1993) Particle flux and composition of sedimenting matter in the Greenland Sea. J Mar Syst 5:411-423

Bauerfeind E, Gonzáles H, Haupt O, Peinert R (2001) Contribution of faecal matter to particulate carbon export. Case studies from the seasonally-ice-covered Greenland Sea. Abstracts of papers presented at the American Society of Limnology and Oceanography Meeting, Albuquerque, New Mexico, February 12 to 16, 2001, p 21

Baylor ER, Sutcliffe WH (1963) Dissolved organic matter in sea water as a source of particulate food. Limnol Oceanogr 8:369-371

Baylor ER, Sutcliffe WH, Hirschfeld DS (1962) Adsorption of phosphates onto bubbles. Deep-Sea Res 9:120-124

Bé AWH, Bishop JKB, Sverdlove MS, Gardner WD (1985) Standing stock, vertical distribution and flux of planktonic Foraminifera in the Panama Basin. Mar Micropaleontol 9: 307-333

Beaufort L, Heussner S (1999) Coccolithophorids on the continental slope of the Bay of Biscay - production, transport and contribution to mass fluxes. Deep-Sea Res II 46: $2147-2174$

Beaulieu SE, Smith KL Jr (1998) Phytodetritus entering the benthic boundary layer and aggregated on the sea floor in the abyssal NE Pacific: macro- and microscopic composition. Deep-Sea Res II 45:781-815

Beers JR, Trent JD, Reid FMH, Shanks AL (1986) Macroaggregates and their phytoplanktonic components in the Southern California Bight. J Plankton Res 8:475-487

Benitez-Nelson C, Buessler KO, Karl DM, Andrews J (2001) A time-series study of particulate matter export in the North Pacific subtropical gyre based on ${ }^{234} \mathrm{Th}:{ }^{238} \mathrm{U}$ disequilibrium. Deep-Sea Res I 48:2595-2611

Benli HA (1987) Investigation of plankton distribution in the southern Black Sea and its effect on particle flux. Mitt Geol-Paläontol Inst Univ Hamburg 62:77-87

Berelson WM, Anderson RF, Dymond J, Demaster D and 8 others (1997) Biogenic budgets of particle rain, benthic remineralization and sediment accumulation in the equatorial Pacific. Deep-Sea Res II 44:2251-2282

Berger WH, Wefer G (1990) Export production: seasonality and intermittency, and paleoceanographic implications. Palaeogeogr Palaeoclimatol Palaeoecol 89:245-254

Bernstein RE, Betzer PR, Feely RA, Byrne RH, Lamb MF, Michaels AF (1987) Acantharian fluxes and strontium to chlorinity ratios in the North Pacific Ocean. Science 237: 1490-1494 
Bernstein RE, Betzer PE, Takahashi K (1990) Radiolarians from the western North Pacific Ocean: a latitudinal study of their distribution and fluxes. Deep-Sea Res 37: $1677-1696$

Betzer PR, Byrne RH, Acker JG, Lewis CS, Jolley RR, Feely RA (1984a) The oceanic carbonate system: a reassessment of biogenic controls. Science 226:1074-1077

Betzer PR, Showers WJ, Laws EA, Winn CD, DiTullio GR, Kroopnick PM (1984b) Primary productivity and particle fluxes on a transect of the equator at $153^{\circ} \mathrm{W}$ in the Pacific Ocean. Deep-Sea Res 31:1-11

Bhosle NB, Sawant SS, Sankaran PD, Wagh AB (1989) Sedimentation of particulate material in stratified and nonstratified water columns in the Bombay High area of the Arabian Sea. Mar Ecol Prog Ser 57:225-236

Bianchi M, Marty D, Teyssié JL, Fowler SW (1992) Strictly aerobic and anaerobic bacteria associated with sinking particulate matter and zooplankton fecal pellets. Mar Ecol Prog Ser 88:55-60

Biddanda BA (1985) Microbial synthesis of macroparticulate matter. Mar Ecol Prog Ser 20:241-251

Biddanda BA (1986) Structure and function of marine microbial aggregates. Oceanol Acta 9:209-211

Biddanda BA (1988) Microbial aggregation and degradation of phytoplankton-derived detritus in seawater. II. Microbial metabolism. Mar Ecol Prog Ser 42:89-95

Biddanda BA, Pomeroy LR (1988) Microbial aggregation and degradation of phytoplankton-derived detritus in seawater. I. Microbial succession. Mar Ecol Prog Ser 42:79-88

Bienfang PK (1980) Herbivore diet affects fecal pellet settling. Can J Fish Aquat Sci 37:1352-1357

Billett DSM, Lampitt RS, Rice AL, Mantoura RFC (1983) Seasonal sedimentation of phytoplankton to the deep-sea benthos. Nature 302:520-522

Biscaye PE, Anderson RF (1994) Fluxes of particulate matter on the slope of the southern Middle Atlantic Bight: SEEPII. Deep-Sea Res II 41:459-510

Biscaye PE, Anderson RF, Deck BL (1988) Fluxes of particles and constituents to the eastern United States continental slope and rise: SEEP-I. Cont Shelf Res 8:855-904

Bishop JKB (1989) Regional extremes in particulate matter composition and flux: effects on the chemistry of the ocean interior. In: Berger WH, Smetacek VS, Wefer G (eds) Productivity of the ocean: present and past. John Wiley \& Sons, Chichester, p 117-137

Bishop JKB, Joyce TM (1986) Spatial distributions and variability of suspended particulate matter in warm core ring 82B. Deep-Sea Res 33:1741-1760

Bishop JKB, Marra J (1984) Variations in primary production and particulate carbon flux through the base of the euphotic zone at the site of the Sediment Trap Intercomparison Experiment (Panama Basin). J Mar Res 42: 189-206

Bishop JKB, Edmond JM, Ketten DR, Bacon MP, Silker WB (1977) The chemistry, biology, and vertical flux of particulate matter from the upper $400 \mathrm{~m}$ of the equatorial Atlantic Ocean. Deep-Sea Res 24:511-548

Bishop JKB, Ketten DR, Edmond JM (1978) The chemistry, biology and vertical flux of particulate matter from the upper $400 \mathrm{~m}$ of the Cape Basin in the southeast Atlantic Ocean. Deep-Sea Res 25:1121-1161

Bishop JKB, Collier RW, Ketten DR, Edmond JM (1980) The chemistry, biology and vertical flux of particulate matter from the upper $1500 \mathrm{~m}$ of the Panama Basin. Deep-Sea Res 27A:615-640

Bishop JKB, Stepien JC, Wiebe PH (1986a) Particulate matter distributions, chemistry and flux in the Panama Basin: response to environmental forcing. Prog Oceanogr 17 : $1-59$

Bishop JKB, Conte MH, Wiebe $\mathrm{PH}$, Roman MR, Langdon C (1986b) Particulate matter production and consumption in deep mixing layers: observations in a warm-core ring. Deep-Sea Res 33:1813-1841

Bishop JKB, Smith RC, Baker K (1992) Springtime distributions and variability of biogenic particulate matter in Gulf Stream warm-core ring 82B and surrounding NW Atlantic waters. Deep-Sea Res 39(Suppl 1A):S295-S325

Bishop JKB, Calvert SE, Soon MYS (1999) Spatial and temporal variability of POC in the northeast subarctic Pacific. Deep-Sea Res II 46:2699-2733

Blomqvist S, Kofoed C (1981) Sediment trapping - a subaquatic in situ experiment. Limnol Oceanogr 26:585-590

Bochdansky AB, Herndl GJ (1992a) Ecology of amorphous aggregations (marine snow) in the northern Adriatic Sea. III. Zooplankton interactions with marine snow. Mar Ecol Prog Ser 87:135-146

Bochdansky AB, Herndl GJ (1992b) Ecology of amorphous aggregations (marine snow) in the Northern Adriatic Sea. V. Role of fecal pellets in marine snow. Mar Ecol Prog Ser 89:297-303

Bochdansky AB, Puskaric S, Herndl GJ (1995) Influence of zooplankton grazing on free dissolved enzymes in the sea. Mar Ecol Prog Ser 121:53-63

Bode A, Varela M, Barquero S, Alvarez-Ossorio MT, Gonzalez N (1998) Preliminary studies on the export of organic matter during phytoplankton blooms off La Coruña (north-western Spain). J Mar Biol Assoc UK 78:1-15

Bodungen BV (1986) Phytoplankton growth and krill grazing during spring in the Bransfield Strait, Antarctica - implications from sediment trap collections. Polar Biol 6:153-160

Bodungen BV, Bröckel KV, Smetacek V, Zeitzschel B (1981) Growth and sedimentation of the phytoplankton spring bloom in the Bornholm Sea (Baltic Sea). Kieler Meeresforsch Sonderh 5:49-60

Bodungen BV, Smetacek VS, Tilzer MM, Zeitzschel B (1986) Primary production and sedimentation during spring in the Antarctic Peninsula region. Deep-Sea Res 33:177-194

Bodungen BV, Fischer G, Nöthig EM, Wefer G (1987) Sedimentation of krill faeces during spring development of phytoplankton in Bransfield Strait, Antarctica. Mitt GeolPaläontol Inst Univ Hamburg 62:243-257

Bodungen BV, Nöthig EM, Sui Q (1988) New production of phytoplankton and sedimentation during summer 1985 in the south eastern Weddell Sea. Comp Biochem Physiol 90B: $475-487$

Bodungen BV, Wunsch M, Fürderer H (1991) Sampling and analysis of suspended and sinking particles in the northern North Atlantic. In: Marine particles: analysis and characterization. AGU Geophys Monogr 63:47-56

Bodungen BV, Antia A, Bauerfeind E, Haupt O and 10 others (1995) Pelagic processes and vertical flux of particles: an overview of long-term comparative study in the Norwegian Sea and Greenland Sea. Geol Rundsch 84:11-27

Boltovskoy D, Alder VA, Abelmann A (1993) Annual flux of Radiolaria and other shelled plankters in the eastern equatorial Atlantic at $853 \mathrm{~m}$ : seasonal variations and polycystine species-spedific responses. Deep-Sea Res I 40: 1863-1895

Boyd P, Newton P (1997) Measuring the biogenic carbon flux in the ocean. Science 275:554-555

Boyd PW, Newton PP (1999) Does planktonic community structure determine downward particulate organic carbon flux in different oceanic provinces? Deep-Sea Res I 46: $63-91$ 
Boyd PW, Sherry ND, Berges JA, Bishop JKB and 13 others (1999) Transformations of biogenic particulates from the pelagic to the deep ocean realm. Deep-Sea Res II 46: 2761-2792

Bradford-Grieve JM, Nodder SD, Jillett JB, Currie K, Lassey KR (2001) Potential contribution that the copepod Neocalanus tonsus makes to downward carbon flux in the Southern Ocean. J. Plankton Res 23:963-975

Bradshaw SA, O'Hara SCM, Corner EDS, Eglinton G (1989) Assimilation of dietary sterols and faecal contribution of lipids by the marine invertebrates Neomysis integer, Scrobicularia plana and Nereis diversicolor. J Mar Biol Assoc UK 69:891-911

Bray RN, Miller AC, Geesey GG (1981) The fish connection: a trophic link between planktonic and rocky reef communities? Science 214:204-205

Brewer PG, Nozaki Y, Spencer DW, Fleer AP (1980) Sediment trap experiments in the deep North Atlantic: isotopic and elemental fluxes. J Mar Res 38:703-728

Broerse ATC, Brummer GJA, Van Hinte JE (2000a) Coccolithophore export production in response to monsoonal upwelling off Somalia (northwesters Indian Ocean). DeepSea Res II 47:2179-2205

Broerse ATC, Ziveri P, van Hinte JE, Honjo S (2000b) Coccolithophore export production, species composition, and coccolith- $\mathrm{CaCO}_{3}$ fluxes in the NE Atlantic $\left(34^{\circ} \mathrm{N} 21^{\circ} \mathrm{W}\right.$ and $48^{\circ} \mathrm{N} 21^{\circ} \mathrm{W}$ ). Deep-Sea Res II 47:1877-1905

Broman D, Colomsjö A, Ganning B, Näf C, Zebühr Y, Östman C (1987) 'Fingerprinting' petroleum hydrocarbons in bottom sediment, plankton, and sediment trap collected seston. Mar Pollut Bull 18:380-388

Bruland KW, Silver MW (1981) Sinking rates of fecal pellets from gelatinous zooplankton (salps, pteropods, doliolids). Mar Biol 63:295-300

Bruland KW, Bienfang PK, Bishop JKB, Eglinton G and 6 others (1989) Group report. Flux to the seafloor. In: Berger WH, Smetacek VS, Wefer G (eds) Productivity of the ocean: present and past. John Wiley \& Sons, Chichester, p 193-215

Buck KR, Chavez FP (1994) Diatom aggregates from the open ocean. J Plankton Res 16:1449-1457

Buck KR, Newton J (1995) Fecal pellet flux in Dabob Bay during a diatom bloom: contribution of microzooplankton. Limnol Oceanogr 40:306-315

Buck KR, Bolt PA, Garrison DL (1990) Phagotrophy and fecal pellet production by an athecate dinoflagellate in Antarctic sea ice. Mar Ecol Prog Ser 60:75-84

Buesseler KO (1991) Do upper-ocean sediment traps provide an accurate record of particle flux? Nature 353:420-423

Buesseler KO, Livingston HD, Honjo S, Hay BJ and 5 others (1987) Chernobyl radionuclides in a Black Sea sediment trap. Nature 329:825-828

Buesseler KO, Livingston HD, Honjo S, Hay BJ, Konuk T, Kempe S (1990) Scavenging and particle deposition in the southwestern Black Sea - evidence from Chernobyl radiotracers. Deep-Sea Res 37:413-430

Buesseler KO, Andrews JA, Hartman MC, Belastock R, Chai F (1995) Regional estimates of the export flux of particulate organic carbon derived from thorium-234 during the JGOFS EqPac program. Deep-Sea Res II 42:777-804

Burns KA, Villeneuve JP (1983) Biogeochemical processes affecting the distribution and vertical transport of hydrocarbon residues in the coastal Mediterranean. Geochim Cosmochim Acta 47:995-1006

Burns KA, Villeneuve JP, Fowler SW (1985) Fluxes and residence times of hydrocarbons in the coastal Mediterranean: how important are the biota? Est Coast Shelf Sci 20:313-330
Butler M, Dam HG (1994) Production rates and characteristics of fecal pellets of the copepod Acartia tonsa under simulated phytoplankton bloom conditions: implications for vertical fluxes. Mar Ecol Prog Ser 114:81-91

Butterfield NJ (1997) Plankton ecology and the ProterozoicPhanerozoic transition. Paleobiology 23:247-262

Cadée GC (1985) Macroaggregates of Emiliana huxleyi in sediment traps. Mar Ecol Prog Ser 24:193-196

Cadée GC (1986) Organic carbon in the water column and its sedimentation, Fladen Ground (North Sea), May 1983. Neth J Sea Res 20:347-358

Cadée GC, González H, Schnack-Schiel SB (1992) Krill diet affects faecal string settling. Polar Biol 12:75-80

Cailliau C, Belviso S, Goutx M, Bedo A, Park Y, Charriaud E (1999) Sedimentation pathways in the Indian sector of the Southern Ocean during a production regime dominated by regeneration. Mar Ecol Prog Ser 190:53-67

Carey AG Jr (1987) Particle flux beneath fast ice in the shallow southwestern Beaufort Sea, Arctic Ocean. Mar Ecol Prog Ser 40:247-257

Carlotti F, Rey C, Javanshir A, Nival S (1997) Laboratory studies on egg and faecal pellet production of Centropages typicus: effect of age, effect of temperature, individual variability. J Plankton Res 19:1143-1165

Carlson CA, Ducklow HW, Michaels AF (1994) Annual flux of dissolved organic carbon from the euphotic zone in the northwestern Sargasso Sea. Nature 371:405-408

Caron DA, Davis PG, Madin LP, Sieburth JMN (1982) Heterotrophic bacteria and bacterivorous protozoa in oceanic macroaggregates. Science 218:795-797

Caron DA, Davis PG, Madin LP, Sieburth JMN (1986) Enrichment of microbial populations in macroaggregates (marine snow) from surface waters of the North Atlantic. J Mar Res 44:543-565

Caron DA, Madin LP, Cole JJ (1989) Composition and degradation of salp fecal pellets: implications for vertical flux in oceanic environments. J Mar Res 47:829-850

Carroll ML, Miquel JC, Fowler SW (1998) Seasonal patterns and depth-specific trends of zooplankton fecal pellet fluxes in the northwestern Mediterranean Sea. Deep-Sea Res I 45:1303-1318

Carson RL (1951) The sea around us. Oxford University Press, New York

Charette MA, Moran SB, Bishop JKB (1999) ${ }^{234}$ Th as a tracer of particulate organic carbon export in the subarctic northeast Pacific Ocean. Deep-Sea Res II 46:2833-2861

Chester AJ, Larrance JD (1981) Composition and vertical flux of organic matter in a large Alaskan estuary. Estuaries 4: 42-52

Christian JR, Lewis MR, Karl DM (1997) Vertical fluxes of carbon, nitrogen, and phosphorus in the North Pacific subtropical gyre near Hawaii. J Geophys Res 102C: 15667-15677

Christiansen B, Beckmann W, Weikert H (2001) The structure and carbon demand of the bathyal benthic boundary layer community: a comparison of two oceanic locations in the NE-Atlantic. Deep-Sea Res II 48:2409-2424

Clarke A, Quetin LB, Ross RM (1988) Laboratory and field estimates of the rate of fecal pellet production by Antarctic krill, Euphausia superba. Mar Biol 98:557-563

Claustre H, Poulet SA, Williams R, Ben-Mlih F, MartinJézéquel V, Marty JC (1992) Relationship between the qualitative nature of particles and copepod faeces in the Irish Sea. Mar Chem. 40:231-248

Coale KH (1990) Labyrinth of doom: a device to minimize the 'swimmer' component in sediment trap collections. Limnol Oceanogr 35:1376-1381 
Coale KH, Bruland KW (1987) Oceanic stratified euphotic zone as elucidated by ${ }^{234} \mathrm{Th}:{ }^{238} \mathrm{U}$ disequilibria. Limnol Oceanogr 32:189-200

Codispoti LA, Packard TT (1980) Denitrification rates in the eastern tropical south Pacific. J Mar Res 38:453-477

Cole JJ, Honjo S, Erez J (1987) Benthic decomposition of organic matter at a deep-water site in the Panama Basin. Nature 327:703-704

Collier R, Dymond J, Honjo S, Manganini S, Francois R, Dunbar R (2000) The vertical flux of biogenic and lithogenic material in the Ross Sea: moored sediment trap observations 1996-1998. Deep-Sea Res II 47:3491-3520

Conan SMH, Brummer GJA (2000) Fluxes of planktic foraminifera in response to monsoonal upwelling on the Somalia Basin margin. Deep-Sea Res II 47:2207-2227

Conley DJ, Johnstone RW (1995) Biogeochemistry of N, P and $\mathrm{Si}$ in Baltic Sea sediments: response to a simulated deposition of a spring diatom bloom. Mar Ecol Prog Ser 122: 265-276

Conte M (1997) The oceanic flux program. Oceanus 40:15-19

Conte MH, Weber JC, Ralph N (1998) Episodic particle flux in the deep Sargasso Sea: an organic geochemical assessment. Deep-Sea Res I 45:1819-1841

Conte MH, Ralph N, Ross EH (2001) Seasonal and interannual variability in deep ocean particle fluxes at the Oceanic Flux Program (OFP)/Bermuda Atlantic Time Series (BATS) site in the western Sargasso Sea near Bermuda. Deep-Sea Res II 48:1471-1505

Corner EDS, O'Hara SCM, Neal AC, Eglinton G (1986) Copepod faecal pellets and the vertical flux of biolipids. In: Corner EDS, O'Hara SCM (eds) The biological chemistry of marine copepods. Clarendon Press, Oxford, p 260-321

Costello DK, Carder KL, Betzer PR, Young RW (1989) In situ holographic imaging of settling particles: applications for individual particle dynamics and oceanic flux measurements. Deep-Sea Res 36:1595-1605

Cowen JP (1992) Morphological study of marine bacterial capsules: implications for marine aggregates. Mar Biol 114:85-95

Cowen JP, Bruland KW (1985) Metal deposits associated with bacteria: implications for Fe and Mn marine biogeochemistry. Deep-Sea Res 32:253-272

Cowen JP, Silver MW (1984) The association of iron and manganese with bacteria on marine macroparticulate material. Science 224:1340-1342

Crisp PT, Brenner S, Venkatesan MI, Ruth E, Kaplan IR (1979) Organic chemical characterization of sediment-trap particulates from San Nicolas, Santa Barbara, Santa Monica and San Pedro Basins, California. Geochim Cosmochim Acta 43:1791-1801

Curry WB, Ostermann DR (1997) Ground-truthing the paleoclimate record. Oceanus 40:11-14

Dadou I, Lamy F, Rabouille C, Ruiz-Pino D and 3 others (2001) An integrated biological pump model from the euphotic zone to the sediment: a 1-D application in the northeast tropical Atlantic. Deep-Sea Res II 48:2345-2381

Dagg MJ (1993) Sinking particles as a possible source of nutrition for the large calanoid copepod Neocalanus cristatus in the subarctic Pacific Ocean. Deep-Sea Res I 40: 1431-1445

Dagg MJ (1995) A comment on 'Variability due to feeding activity of individual copepods' (Paffenhöfer, 1994). J Plankton Res 17:903-905

Dagg MJ, Walser WE (1986) The effect of food concentration on fecal pellet size in marine copepods. Limnol Oceanogr 31:1066-1071

Dagg MJ, Walser WE (1987) Ingestion, gut passage, and egestion by the copepod Neocalanus plumchrus in the laboratory and in the subarctic Pacific Ocean. Limnol Oceanogr 32:178-188

Dagg MJ, Frost BW, Walser WE (1989) Copepod diel migration, feeding, and the vertical flux of phaeopigments. Limnol Oceanogr 34:1062-1071

Dagg MJ, Green EP, McKee BA, Ortner PB (1996) Biological removal of fine-grained lithogenic particles from a large river plume. J Mar Res 54:149-160

Daly LK, DiTullio GR (1996) Particulate dimethylsulfioproprionate removal and dimethylsulfide production by zooplankton in the Southern Ocean. In: Kiene RP, Visscher PT, Keller MD, Kirst GO (eds) Biological and environmental chemistry of DMSP and related sulfonium compounds. Plenum Press, New York, p 233-238

Dam HG, Feinberg LR (2001) Materials for modeling zooplankton fecal pellet flux in the oceans: reanalysis of allometric relationships related to pellet sinking. Abstracts of papers presented at the American Society of Limnology and Oceanography Meeting, Albuquerque, New Mexico, February 12 to 16, 2001, p 42

Dam HG, Roman MR, Youngbluth MJ (1995) Downward export of respiratory carbon and dissolved inorganic nitrogen by diel-migrant mesozooplankton at the JGOFS Bermuda time-series station. Deep-Sea Res I 42: 1187-1197

Danovaro R, Dinet A, Duineveld G, Tselepides A (1999) Benthic response to particulate fluxes in different trophic environments: a comparison between the Gulf of Lions Catalan Sea (western Mediterranean) and the Cretan Sea (eastern Mediterranean). Prog Oceanogr 44:287-312

Danovaro R, Tselepides A, Otegui A, Della Croce N (2000a) Dynamics of meiofaunal assemblages on the continental shelf and deep-sea sediments of the Cretan Sea (NE Mediterranean): relationships with seasonal changes in food supply. Prog Oceanogr 46:367-400

Danovaro R, Della Croce N, Dell'Anno A, Fabiano M, Marrale D, Martorano D (2000b) Seasonal changes and biochemical composition of the labile organic matter flux in the Cretan Sea. Prog Oceanogr 46:259-278

Danovaro R, Marrale D, Dell'Anno A, Della Croce N, Tselepides A, Fabiano M (2000c) Bacterial response to seasonal changes in labile organic matter composition on the continental shelf and bathyal sediments of the Cretan Sea. Prog Oceanogr 46:345-366

Davies JM, Payne R (1984) Supply of organic matter to the sediment in the northern North Sea during a spring phytoplankton bloom. Mar Biol 78:315-324

Davoll PJ, Silver MW (1986) Marine snow aggregates: life history sequence and microbial community of abandoned larvacean houses from Monterey Bay, California. Mar Ecol Prog Ser 33:111-120

Davoll PJ, Youngbluth MJ (1990) Heterotrophic activity on appendicularian (Tunicata: Appendicularia) houses in mesopelagic regions and their potential contribution to particle flux. Deep-Sea Res 37:285-294

De Baar HJW, Farrington JW, Wakeham SG (1983) Vertical flux of fatty acids in the North Atlantic Ocean. J Mar Res 41:19-41

Deibel D (1990) Still-water sinking velocity of fecal material from the pelagic tunicate Dolioletta gegenbauri. Mar Ecol Prog Ser 62:55-60

Delille D, Razouls S (1994) Community structures of heterotrophic bacteria of copepod fecal pellets. J Plankton Res 16:603-615

DeLong EF, Franks DG, Alldredge AL (1993) Phylogenetic diversity of aggregate-attached vs. free-living marine 
bacteria assemblages. Limnol Oceanogr 38:924-934

Deming JW (1985) Bacterial growth in deep-sea sediment trap and boxcore samples. Mar Ecol Prog Ser 25:305-312

Deming JW, Colwell RR (1985) Observations of barophilic microbial activity in samples of sediment and intercepted particulates from the Demerara Abyssal Plain. Appl Environ Microbiol 50:1002-1006

Deuser WG (1986) Seasonal and interannual variations in deep-water particle fluxes in the Sargasso Sea and their relation to surface hydrography. Deep-Sea Res 33: 225-246

Deuser WG (1987) Variability of hydrography and particle flux: transient and long-term relationships. Mitt GeolPaläontol Inst Univ Hamburg 62:179-193

Deuser WG, Ross EH (1980) Seasonal change in the flux of organic carbon to the deep Sargasso Sea. Nature 283: 364-365

Deuser WG, Ross EH (1989) Seasonally abundant planktonic Foraminifera of the Sargasso Sea: succession, deep-water fluxes, isotopic compositions, and paleoceanographic implications. J Foraminiferal Res 19:268-293

Deuser WG, Ross EH, Anderson RF (1981a) Seasonality in the supply of sediment to the deep Sargasso Sea and implications for the rapid transfer of matter to the deep ocean. Deep-Sea Res 28A:495-505

Deuser WG, Ross EH, Hemleben C, Spindler M (1981b) Seasonal changes in species composition, numbers, mass, size, and isotopic composition of planktonic foraminifera settling into the deep Sargasso Sea. Palaeogeogr Palaeoclimatol Palaeoecol 33:103-127

Deuser WG, Brewer PG, Jickells TD, Commeau RF (1983a) Biological control of the removal of abiogenic particles from the surface ocean. Science 219:388-391

Deuser WG, Emeis K, Ittekkot V, Degens ET (1983b) Fly-ash particles intercepted in the deep Sargasso Sea. Nature 305:216-218

Deuser WG, Muller-Karger FE, Hemleben C (1988) Temporal variations of particle fluxes in the deep subtropical and tropical North Atlantic: Eulerian versus Lagrangian effects. J Geophys Res 93:6857-6882

Deuser WG, Muller-Karger FE, Evans RH, Brown OB, Esaias WE, Faldman GC (1990) Surface-ocean color and deepocean carbon flux: how close a connection? Deep-Sea Res $37: 1331-1343$

Deuser WG, Jickells TD, King P, Commeau JA (1995) Decadal and annual changes in biogenic opal and carbonate fluxes to the deep Sargasso Sea. Deep-Sea Res I 42:1923-1932

Diercks AR, Asper VL (1997) In situ settling speeds of marine snow aggregates below the mixed layer: Black Sea and Gulf of Mexico. Deep-Sea Res I 44:385-398

Dilling L, Alldredge AL (1993) Can chaetognath fecal pellets contribute significantly to carbon flux? Mar Ecol Prog Ser 92:51-58

Dilling L, Alldredge AL (2000) Fragmentation of marine snow by swimming macrozooplankton: a new process impacting carbon cycling in the sea. Deep-Sea Res I 47: $1227-1245$

Dilling L, Wilson J, Steinberg D, Alldredge A (1998) Feeding by the euphausiid Euphausia pacifica and the copepod Calanus pacificus on marine snow. Mar Ecol Prog Ser 170: 189-201

DiTullio GR, Grebmeier JM, Arrigo KR, Lizotte MP and 5 others (2000) Rapid and early export of Phaeocystis antarctica blooms in the Ross Sea, Antarctica. Nature 404:595-598

Doney SC (1997) The ocean's productive deserts. Nature 389: 905-906

Dortch Q, Robichaux R, Pool S, Milsted D and 6 others (1997)
Abundance and vertical flux of Pseudo-nitzschia in the northern Gulf of Mexico. Mar Ecol Prog Ser 146:249-264

Downs JN, Lorenzen CJ (1985) Carbon:phaeopigment ratios of zooplankton fecal pellets as an index of herbivorous feeding. Limnol Oceanogr 30:1024-1036

Drazen JC, Baldwin RJ, Smith KL Jr (1998) Sediment community response to a temporally varying food supply at an abyssal station in the NE pacific. Deep-Sea Res II 45: 893-913

Druffel ERM, Robison BH (1999) Is the deep sea on a diet? Science 284:1139-1140

Druffel ERM, Griffin S, Bauer JE, Wolgast DM, Wang XC (1998) Distribution of particulate organic carbon and radiocarbon in the water column from the upper slope to the abyssal NE Pacific Ocean. Deep-Sea Res II 45:667-687

Ducklow HW, Kirchman DL, Rowe GT (1982) Production and vertical flux of attached bacteria in the Hudson River plume of the New York Bight as studied with floating sediment traps. Appl Environ Microbiol 43:769-776

Ducklow HW, Hill SM, Gardner WD (1985) Bacterial growth and the decomposition of particulate organic carbon collected in sediment traps. Cont Shelf Res 4:445-464

Dugdale RC, Goering JJ (1967) Uptake of new and regenerated forms of nitrogen in primary productivity. Limnol Oceanogr 12:196-206

Duineveld GCA, Lavaleye MSS, Berghuis EM, De Wilde PAWJ and 4 others (1997) Patterns of benthic fauna and benthic respiration on the Celtic continental margin in relation to the distribution of phytodetritus. Int Rev Gesamten Hydrobiol 82:395-424

Duineveld GCA, Tselepides A, Witbaard R, Bak RPM and 4 others (2000) Benthic-pelagic coupling in the oligotrophic Cretan Sea. Prog Oceanogr 46:457-480

Dunbar RB (1984) Sediment trap experiments on the Antarctic continental margin. Antarct J US 19:70-71

Dunbar RB, Berger WH (1981) Fecal pellet flux to modern bottom sediment of Santa Barbara Basin (California) based on sediment trapping. Geol Soc Am Bull I 92:212-218

Dunbar RB, Leventer AR, Mucciarone DA (1998) Water column sediment fluxes in the Ross Sea, Antarctica: atmosphere and sea forcing. J Geophys Res 103(C13): 30741-30759

Dymond J, Collier R (1988) Biogenic particle fluxes in the equatorial Pacific: evidence for both high and low productivity during the 1982-1983 El Niño. Global Biogeochem Cycles 2:129-137

Dymond J, Collier R (1996) Particulate barium fluxes and their relationships to biological productivity. Deep-Sea Res II 43:1283-1308

Dymond J, Lyle M (1985) Flux comparisons between sediments and sediment traps in the eastern tropical Pacific: implications for atmospheric $\mathrm{CO}_{2}$ variations during the Pleistocene. Limnol Oceanogr 30:699-712

Dymond J, Fischer K, Clauson M, Cobler R and 5 others (1981) A sediment trap intercomparison study in the Santa Barbara Basin. Earth Planet Sci Lett 53:409-418

Eisma D (1987) Flocculation of suspended matter in coastal waters. Mitt Geol-Paläontol Inst Univ Hamburg 62: 259-268

Elbrächter M (1991) Faeces production by dinoflagellates and other small flagellates. Mar Microb Food Webs 5:189-204

Emerson S, Hedges JJ (1988) Processes controlling the organic carbon content of open ocean sediments. Paleoceanography 3:621-634

Emerson CW, Roff JC (1987) Implications of fecal pellet size and zooplankton behaviour to estimates of pelagic-benthic carbon flux. Mar Ecol Prog Ser 35:251-257 
Emerson CW, Roff JC, Wildish DJ (1986) Pelagic-benthic energy coupling at the mouth of the Bay of Fundy. Ophelia 26:165-180

Emerson S, Quay P, Karl D, Winn C, Tupas L, Landry M (1997) Experimental determination of the organic carbon flux from open-ocean surface waters. Nature 389:951-954

Engel A, Schartau M (1999) Influence of transparent exopolymer particles (TEP) on sinking velocity of Nitzschia closterium aggregates. Mar Ecol Prog Ser 182:69-76

Eppley RW, Peterson BJ (1979) Particulate organic matter flux and planktonic new production in the deep ocean. Nature 282:677-680

Etcheber H, Huessner S, Weber O, Dinet A and 4 others (1996) Organic carbon fluxes and sediment biogeochemistry on the French Mediterranean and Atlantic margins. In: Ittekkot V, Schäfer P, Honjo S, Depetris PJ (eds) Particle flux in the ocean, SCOPE 57. John Wiley \& Sons, New York, p 223-242

Fabry VJ, Deuser WG (1991) Aragonite and magnesium clacite fluxes to the deep Sargasso Sea. Deep-Sea Res 38: $713-728$

Faganeli J (1989) Sedimentation of particulate nitrogen and amino acids in shallow coastal waters (Gulf of Trieste, northern Adriatic). Mar Chem 26:67-80

Falkowski PG, Vidal J, Hopkins TS, Rowe GT, Whitledge TE, Harrison WG (1983) Summer nutrient dynamics in the Middle Atlantic Bight: primary production and utilization of plankton carbon. J Plankton Res 5:515-537

Falkowski PG, Biscaye PE, Sancetta C (1994) The lateral flux of biogenic particles from the eastern North American continental margin to the North Atlantic Ocean. Deep-Sea Res II 41:583-601

Falkowski P, Scholes RJ, Boyle E, Canadell J and 13 others (2000) The global carbon cycle: a test of our knowledge of Earth as a system. Science 290:291-296

Feely RA, Chester AJ, Paulson AJ, Larrance JD (1982) Relationships between organically bound $\mathrm{Cu}$ and $\mathrm{Mn}$ in settling particulate matter and biological processes in a subarctic estuary. Estuaries 5:74-80

Feely RA, Massoth GJ, Baker ET, Gendron JF, Paulson AJ, Crecelius EA (1986) Seasonal and vertical variations in the elemental composition of suspended and settling particulate matter in Puget Sound, Washington. Est Coast Shelf Sci 22:215-239

Feinberg LR, Dam HG (1998) Effects of diet on dimension, density and sinking rates of fecal pellets of the copepod Acartia tonsa. Mar Ecol Prog Ser 173:87-96

Fellows DA, Karl DM, Knauer GA (1981) Large particle fluxes and the vertical transport of living carbon in the upper $1500 \mathrm{~m}$ of the northeast Pacific Ocean. Deep-Sea Res 28A:921-936

Fischer G, Fütterer, Gersonde R, Honjo S, Ostermann D, Wefer G (1988) Seasonal variability of particle flux in the Weddell Sea and its relation to ice cover. Nature 335: 426-428

Fischer G, Neuer S, Wefer G, Krause G (1996) Short-term sedimentation pulses recorded with a fluorescence sensor and sediment traps at 900-m depth in the Canary Basin. Limnol Oceanogr 41:1354-1359

Fischer G, Ratmeyer V, Wefer G (2000) Organic carbon fluxes in the Atlantic and the Southern Ocean: relationship to primary production compiled from satellite radiometer data. Deep-Sea Res II 47:1961-1997

Fisher NS, Cochran JK, Krishnaswami S, Livingston HD (1988) Predicting the oceanic flux of radionuclides on sinking biogenic debris. Nature 335:622-625

Fisher NS, Nolan CV, Fowler SW (1991) Scavenging and retention of metals by zooplankton fecal pellets and marine snow. Deep-Sea Res 38:1261-1275

Fleeger JW, Shirley TC, Ziemann DA (1989) Meiofaunal responses to sedimentation from an Alaskan spring bloom. I. Major taxa. Mar Ecol Prog Ser 57:137-145

Flood PR, Deibel D, Morris CC (1992) Filtration of colloidal melanin from sea water by plankton tunicates. Nature 355:630-632

Fortier L, LeFèvre J, Legendre L (1994) Export of biogenic carbon to fish and to the deep ocean: the role of large planktonic microphages. J Plankton Res 16:809-839

Fournier RO (1970) Studies on pigmented microorganisms from aphotic marine environments. Limnol Oceanogr 15: $675-682$

Fournier RO (1971) Studies on pigmented microorganisms from aphotic marine environments. II. North Atlantic distribution. Limnol Oceanogr 16:952-961

Fowler SW (1991) Biologically mediated removal, transformation, and regeneration of dissolved elements and compounds. In: Mantoura RFC, Martin JM, Wollast R (eds) Ocean margin processes in global change. John Wiley \& Sons, Chichester, p 127-143

Fowler SW, Fisher NS (1983) Viability of marine phytoplankton in zooplankton fecal pellets. Deep-Sea Res 30:963-969

Fowler SW, Knauer GA (1986) Role of large particles in the transport of elements and organic compounds through the oceanic water column. Prog Oceanogr 16:147-194

Fowler SW, Small LF (1972) Sinking rates of euphausiid fecal pellets. Limnol Oceanogr 17:293-296

Fowler SW, Ballestra S, La Rosa J, Fukai R (1983) Vertical transport of particulate-associated plutonium and americium in the upper water column of the Northwest Pacific. Deep-Sea Res 30:1221-1233

Fowler SW, Villeneuve JP, Burns KA (1986) Vertical flux of hexachlorobenzene in coastal waters of the north-west Mediterranean Sea. In: Morris CR, Cabral JRP (eds) Hexachlorobenzene: proceedings of an International Symposium. International Agency for Research on Cancer, Lyon, p 67-73

Fowler SW, Buat-Menard P, Yokoyama Y, Ballestra S, Holm E, Nguyen HV (1987) Rapid removal of Chernobyl fallout from Mediterranean surface waters by biological activity. Nature 329:56-58

Fowler SW, Small LF, La Rosa J (1991) Seasonal particulate carbon flux in the coastal northwestern Mediterranean Sea, and the role of zooplankton fecal matter. Oceanol Acta 14:77-85

François R, Bacon MP (1997) Geochemical archives encoded in deep-sea sediments offer clues for reconstructing the ocean's role in past climatic changes. Oceanus 40:29-32

Frangoulis C, Belkhiria S, Goffart A, Hecq JH (2001) Dynamics of copepod faecal pellets in relation to a Phaeocystis dominated phytoplankton bloom: characteristics, production and flux. J Plankton Res 23:75-88

Gadel F, Puigbó A, Alcañiz JM, Charrière B, Serve L (1990) Tracers and constituents indicating the nature of organic fluxes, their origin and the effect of environmental conditions. Cont Shelf Res 10:1039-1062

Gagosian RB, Smith SO, Nigrelli GE (1982) Vertical transport of steroid alcohol and ketones measured in a sediment trap experiment in the equatorial Atlantic Ocean. Geochim Cosmochim Acta 46:1163-1172

Gagosian RB, Volkman JK, Nigrelli GE (1983a) The use of sediment traps to determine sterol sources in coastal sediments off Peru. In: Bojoroy $M$ (ed) Advances in organic geochemistry 1981. John Wiley \& Sons, Chichester, p 369-379 
Gagosian RB, Nigrelli GE, Volkman JK (1983b) Vertical transport and transformation of biogenic organic compounds from a sediment trap experiment off the coast of Peru. In: Suess E, Thiede J (eds) Coastal upwelling, its sediment record, Part A. Plenum Press, New York, p 241-272

Gardner WD (1980a) Sediment trap dynamics and calibration: a laboratory evaluation. J Mar Res 38:17-39

Gardner WD (1980b) Field assessment of sediment traps. J Mar Res 38:41-52

Gardner WD, Walsh ID (1990) Distribution of macroaggregates and fine-grained particles across a continental margin and their potential role in fluxes. Deep-Sea Res 37: 401-411

Gardner WD, Hinga KR, Marra J (1983) Observations on the degradation of biogenic material in the deep ocean with implications on accuracy of sediment trap fluxes. J Mar Res 41:195-214

Gardner WD, JKB Bishop, Biscaye PE (1984) Nephelometer and current observations at the STIE site, Panama Basin. J Mar Res 42:207-219

Gardner WD, Walsh ID, Richardson MJ (1993) Biophysical forcing of particle production and distribution during a spring bloom in the North Atlantic. Deep-Sea Res II 40: 171-195

Gardner WD, Richardson MJ, Smith WO Jr (2000) Seasonal patterns of water column particulate organic carbon and fluxes in the Ross Sea, Antarctica. Deep-Sea Res II 47: 3423-3449

Geesey GG, Alexander GV, Bray RN, Miller AC (1984) Fish fecal pellets are a source of minerals for inshore reef communities. Mar Ecol Prog Ser 15:19-25

Giraudeau J, Bailey GW, Pujol C (2000) A high-resolution time-series analysis of particle fluxes in the Northern Benguela coastal upwelling system: carbonate record of changes in biogenic production and particle transfer processes. Deep-Sea Res II 47:1999-2028

Goericke R, Strom SL, Bell MA (2000) Distribution and sources of cyclic phaeophorbides in the marine environment. Limnol Oceanogr 45:200-211

Goldman JC (1993) Potential role of large oceanic diatoms in new primary production. Deep-Sea Res 40:159-168

Goldthwait SA, Yen J, Alldredge AL (2001) Impact of euphausiid swimming on marine snow size and flux. Abstracts of papers presented at the American Society of Limnology and Oceanography Meeting, Albuquerque, New Mexico, February 12 to 16, 2001, p 59

González H (1992a) The distribution and abundance of krill faecal material and oval pellets in the Scotia and Weddell Seas (Antarctica) and their role in particle flux. Polar Biol 12:81-91

González H (1992b) Distribution and abundance of minipellets around the Antarctic Peninsula. Implications for protistan feeding behaviour. Mar Ecol Prog Ser 90:223-236

González H, Biddanda B (1990) Microbial transformation of metazoan (Idotea granulosa) faeces. Mar Biol 106:285-295

González HE, Smetacek V (1994) The possible role of the cyclopoid copepod Oithona in retarding vertical flux of zooplankton fecal material. Mar Ecol Prog Ser 113:233-246

González HE, Kurbjeweit F, Bathmann UV (1994a) Occurrence of cyclopoid copepods and faecal material in the Halley Bay region, Antarctica, during January-February 1991. Polar Biol 14:331-342

González HE, González SR, Brummer GJ A (1994b) Shortterm sedimentation pattern of zooplankton, faeces and microplankton at a permanent station in the Bjørnafjorden (Norway) during April-May 1992. Mar Ecol Prog Ser 105: $31-45$
González HE, Ortiz VC, Sobarzo M (2000a) The role of faecal material in the particulate organic carbon flux in the northern Humboldt Current, Chile $\left(23^{\circ} \mathrm{S}\right)$, before and during the 1997-1998 El Niño. J Plankton Res 22:499-529

González HE, Sobarzo M, Figueroa D, Nöthig EM (2000b) Composition, biomass and potential grazing impact of the crustacean and pelagic tunicates in the northern Humboldt Current area off Chile: differences between El Niño and non-El Niño years. Mar Ecol Prog Ser 195:201-220

Gooday AJ (1988) A response by benthic Foraminifera to the deposition of phytodetritus in the deep sea. Nature 332: $70-73$

Gooday AJ, Lambshead PJD (1989) Influence of seasonally deposited phytodetritus on benthic foraminiferal populations in the bathyal northeast Atlantic: the species response. Mar Ecol Prog Ser 58:53-67

Gooday AJ, Turley CM (1990) Responses by benthic organisms to imputs of organic material to the ocean floor: a review. Philos Trans R Soc Lond 331:119-138

Gordon DC (1970) A microscopic study of organic particles in the North Atlantic Ocean. Deep-Sea Res 17:175-185

Gorsky G, Fisher NS, Fowler SW (1984) Biogenic debris from the pelagic tunicate, Oikopleura dioica, and its role in the vertical transport of a transuranium element. Estuar Coast Shelf Sci 18:13-23

Gotschalk CC, Alldredge AL (1989) Enhanced primary production and nutrient regeneration within aggregated marine diatoms. Mar Biol 103:119-129

Gowing MM (1993) Large virus-like particles from vacuoles of phaeodarian radiolarians and from other marine samples. Mar Ecol Prog Ser 101:33-43

Gowing MM, Silver MW (1983) Origins and microenvironments of bacteria mediating fecal pellet decomposition in the sea. Mar Biol 73:7-16

Gowing MM, Silver MW (1985) Minipellets: a new and abundant size class of marine fecal pellets. J Mar Res 43: 395-418

Gowing MM, Silver MW (1986) Trophic relationships of deepsea calanoid copepods from the benthic boundary layer of the Santa Catalina Basin, California. Deep-Sea Res 33: 939-964

Gowing MM, Garrison DL, Kunze HB, Winchell CJ (2001) Biological components of Ross Sea short-term particle fluxes in the austral summer of 1995-1996. Deep-Sea Res I 48:2645-2671

Graebmeier JM, McRoy CP (1989) Pelagic-benthic coupling on the shelf of the northern Bering and Chukchi Seas. III. Benthic food supply and carbon cycling. Mar Ecol Prog Ser 53:79-91

Graebmeier JM, McRoy CP, Feder HM (1988) Pelagic-benthic coupling on the shelf of the northern Bering and Chukchi Seas. I. Food supply and benthic biomass. Mar Ecol Prog Ser 48:57-67

Graebmeier JM, Feder HM, McRoy CP (1989) Pelagic-benthic coupling on the shelf of the northern Bering and Chukchi Seas. II. Benthic community structure. Mar Ecol Prog Ser 51:253-268

Graf G (1987) Benthic energy flow during a simulated autumn bloom sedimentation. Mar Ecol Prog Ser 39:23-29

Graf G (1989) Benthic-pelagic coupling in a deep-sea benthic community. Nature 341:437-439

Graf G, Bengtsson W, Diesner U, Schulz R, Theede H (1982) Benthic response to sedimentation of a spring phytoplankton bloom: process and budget. Mar Biol 67:201-208

Graf G, Schulz R, Peinert R, Meyer-Reil LA (1983) Benthic response to sedimentation events during autumn to spring at a shallow-water station in the western Kiel Bight. 
Mar Biol 77:235-246

Graf G, Bengtsson W, Faubel A, Meyer-Reil LA and 3 others (1984) The importance of the spring phytoplankton bloom for the benthic system of Kiel Bight. Rapp P-V Réun Cons Int Explor Mer 183:136-143

Graham WM, MacIntyre S, Alldredge AL (2000) Diel variations of marine snow concentration in surface waters and implications for particle flux in the sea. Deep-Sea Res I 47 : 367-395

Green EP, Dagg MJ (1997) Mesozooplankton associations with medium to large marine snow aggregates in the northern Gulf of Mexico. J Plankton Res 19:435-447

Green EP, Harris RP, Duncan A (1992) The production and ingestion of faecal pellets by nauplii of marine calanoid copepods. J Plankton Res 14:1631-1643

Grimalt JO, Simoneit BRT, Gómez-Belinchón JI, Fischer K, Dymond J (1990) Ascending and descending fluxes of lipid compounds in North Atlantic and North Pacific abyssal waters. Nature 345:147-150

Guidi LD, Tito de Morais A (1983) Ascidian faecal pellets and their utilization by an epibenthic amphipod. J Exp Mar Biol Ecol 71:289-298

Gulliksen B (1982) Sedimentation close to a near vertical rocky wall in Balsfjorden, northern Norway. Sarsia 67: $21-27$

Gundersen K, Wassmann P (1990) Use of chloroform in sediment traps: caution advised. Mar Ecol Prog Ser 64: 187-195

Gust G, Kozerski HP (2000) In situ sinking-particle flux from collection rates of cylindrical traps. Mar Ecol Prog Ser 208: 93-106

Gyldenfeldt AB v, Carstens J, Meincke J (2000) Estimation of the catchment area of a sediment trap by means of current meters and foraminiferal tests. Deep-Sea Res II 47: 1701-1717

Haake B, Ittekot V, Riven T, Ramaswamy V, Nair RR, Curry WB (1993) Seasonality and interannual variability of particle fluxes to the deep Arabian Sea. Deep-Sea Res 40: 1323-1344

Haberyan KA (1985) The role of copepod fecal pellets in the deposition of diatoms in Lake Tanganyika. Limnol Oceanogr 30:1010-1023

Haidar AT, Thierstein HR, Deuser WG (2000) Calcareous phytoplankton standing stocks, fluxes and accumulation in Holocene sediments off Bermuda (N. Atlantic). DeepSea Res II 47:1907-1938

Hamm C, Reigstad M, Riser CW, Mühlenbach A, Wassmann P (2001) On the trophic fate of Phaeocystis pouchetii. VII. Sterols and fatty acids reveal sedimentation of $P$. pouchetii-derived organic matter via krill fecal strings. Mar Ecol Prog Ser 209:55-69

Hamner WM (1985) The importance of ethology for investigations of marine zooplankton. Bull Mar Sci 37:414-424

Hamner WM, Madin LP, Alldredge AL, Gilmer RW, Hamner PP (1975) Underwater observations of gelatinous zooplankton: sampling problems, feeding biology, and behavior. Limnol Oceanogr 20:907-917

Hansell DA, Goering JJ, Walsh JJ, McRoy CP, Coachman LK, Whitledge TE (1989) Summer phytoplankton production and transport along the shelf break in the Bering Sea. Cont Shelf Res 9:1085-1104

Hansell DA, Bates NR, Carlson CA (1997a) Predominance of vertical loss of carbon from surface waters of the equatorial Pacific Ocean. Nature 386:59-61

Hansell DA, Carlson CA, Bates NR, Poisson A (1997b) Horizontal and vertical removal of organic carbon in the equatorial Pacific Ocean: a mass balance assessment. Deep-
Sea Res II 44:2115-2130

Hansen B, Bech G (1996) Bacteria associated with a marine planktonic copepod in culture. I. Bacterial genera in seawater, body surface, intestines and fecal pellets and succession during fecal pellet degradation. J Plankton Res 18:257-273

Hansen B, Fotel FL, Jensen NJ, Madsen SD (1996) Bacteria associated with a marine planktonic copepod in culture. II. Degradation of fecal pellets produced on a diatom, a nanoflagellate or a dinoflagellate diet. J Plankton Res 18: $275-288$

Hanson RB, Ducklow HW, Field JG (2000) The changing ocean carbon cycle. A midterm synthesis of the Joint Global Ocean Flux Study. Cambridge University Press

Harada K, Tsunogai S (1986) Fluxes of ${ }^{234} \mathrm{Th},{ }^{210} \mathrm{Po}$ and ${ }^{210} \mathrm{~Pb}$ determined by sediment trap experiments in pelagic oceans. J Oceanogr Soc Jpn 42:192-200

Harada N, Handa N, Harada K, Matsuoka H (2001) Alkenones and particulate fluxes in sediment traps from the central equatorial Pacific. Deep-Sea Res I 48:891-907

Harding GC (1986) Organochlorine dynamics between zooplankton and their environment, a reassessment. Mar Ecol Prog Ser 33:167-191

Harding GC, Hargrave BT, Vass WP, Sheldon RW, Pearre S Jr (1987) Vertical flux of particulate matter by sedimentation and zooplankton movements in St. Georges Bay, the southern Gulf of St. Lawrence. Biol Oceanogr 4:323-357

Hargrave BT (1985) Particle sedimentation in the ocean. Ecol Model 30:229-246

Hargrave BT, Burns NM (1979) Assessment of sediment trap collection efficiency. Limnol Oceanogr 24:1124-1136

Hargrave BT, Taguchi S (1978) Origin of deposited material sedimented in a marine bay. J Fish Res Board Can 35: $1604-1613$

Hargrave BT, Bodungen BV, Conover RJ, Fraser AJ, Phillips G, Vass WP (1989) Seasonal changes in sedimentation of particulate matter and lipid content of zooplankton collected by sediment trap in the Arctic Ocean off Axel Heiberg Island. Polar Biol 9:467-475

Hargrave BT, Bodungen BV, Stoffyn-Egli P, Mudie PJ (1994) Seasonal variability in particle sedimentation under permanent ice cover in the Arctic Ocean. Cont Shelf Res 14: 279-293

Harris JRW, Stutt ED, Turley CM (2001) Carbon flux in the northwest Mediterranean estimated from microbial production. Deep-Sea Res I 48:2631-2644

Harris RP (1994) Zooplankton grazing on the coccolithophore Emiliania huxleyi and its role in inorganic carbon flux. Mar Biol 119:431-439

Hay BJ, Honjo S, Kempe S, Ittekkot VA and 3 others (1990) Interannual variability in particle flux in the southwestern Black Sea. Deep-Sea Res 37:911-928

Hays GC, Harris RP, Head RN (1997) The vertical nitrogen flux caused by zooplankton diel vertical migration. Mar Ecol Prog Ser 160:57-62

Hays GC, Harris RP, Head RN (2001) Diel changes in the near-surface biomass of zooplankton and the carbon content of vertical migrants. Deep-Sea Res II 48:1063-1068

Hayashi M, Furuya K, Hattori H (2001) Spatial heterogeneity in distributions of chlorophyll a derivatives in the subarctic North pacific during summer. J Oceanogr 57:323-331

Head EJH (1988) Copepod feeding behavior and the measurement of grazing rates in vivo and in vitro. Hydrobiologia 167/168:31-41

Head EJH (1992a) Gut pigment accumulation and destruction by arctic copepods in vitro and in situ. Mar Biol 112: $583-592$ 
Head EJH (1992b) Comparison of the chemical composition of particulate material and copepod faecal pellets at stations off the coast of Labrador and in the Gulf of St. Lawrence. Mar Biol 112:593-600

Head EJH, Harris LR (1992) Chlorophyll and carotenoid transformation and destruction by Calanus spp grazing on diatoms. Mar Ecol Prog Ser 86:229-238

Head EJH, Harris LR (1996) Chlorophyll destruction by Calanus spp. grazing on phytoplankton: kinetics, effects of ingestion rate and feeding history, and a mechanistic interpretation. Mar Ecol Prog Ser 135:223-235

Head EJH, Horne EPW (1993) Pigment transformation and vertical flux in an area of convergence in the North Atlantic. Deep-Sea Res 40:329-346

Head EJH, Bedo A, Harris LR (1988) Grazing, defecation and excretion rates of copepods from inter-island channels of the Canadian Arctic archipelago. Mar Biol 99:333-340

Head EJH, Hargrave BT, Subba Rao DV (1994) Accumulation of a phaeophorbide a-like pigment in sediment traps during late stages of a spring bloom: a product of dying algae? Limnol Oceanogr 39:176-181

Hebbeln D (2000) Flux of ice-rafted detritus from sea ice in the Fram Strait. Deep-Sea Res II 47:1773-1790

Hebbeln D, Wefer G (1991) Effects of ice coverage and icerafted material on sedimentation in the Fram Strait. Nature 350:409-411

Hebbeln D, Marchant M, Wefer G (2000) Seasonal variations of the particle flux in the Peru-Chile current at $30^{\circ} \mathrm{S}$ under 'normal' and El Niño conditions. Deep-Sea Res II 47: 2101-2128

Hebel D, Knauer GA, Martin JH (1986) Trace metals in large agglomerates (marine snow). J Plankton Res 8:819-824

Hecker B (1990) Photographic evidence for the rapid flux of particles to the sea floor and their transport down the continental slope. Deep-Sea Res 37:1773-1782

Hedges JI, Clark WA, Cowie GL (1988a) Organic matter sources to the water column and surficial sediments of a marine bay. Limnol Oceanogr 33:1116-1136

Hedges JI, Clark WA, Cowie GL (1988b) Fluxes and reactivities of organic matter in a coastal marine bay. Limnol Oceanogr 33:1137-1152

Hedges JI, Baldock JA, Gélinas Y, Lee C, Peterson M, Wakeham SG (2001) Evidence for non-selective preservation of organic matter in sinking marine particles. Nature 409: 801-804

Heiskanen AS (1995) Contamination of sediment trap fluxes by vertically migrating phototrophic micro-organisms in the coastal Baltic Sea. Mar Ecol Prog Ser 122:45-58

Heiskanen AS, Leppänen JM (1995) Estimation of export production in the coastal Baltic Sea: effect of sediment resuspension and microbial decomposition on sedimentation measurements. Hydrobiologia 316:211-224

Heiskanen AS, Haapala J, Gundersen K (1998) Sedimentation and retention of particulate $\mathrm{C}, \mathrm{N}$ and $\mathrm{P}$ in the coastal northern Baltic Sea. Est Coast Shelf Sci 46:703-712

Heissenberger A, Leppard GG, Herndl GJ (1996) Ultrastructure of marine snow. II. Microbiological considerations. Mar Ecol Prog Ser 135:299-308

Herman PMJ, Soetaert K, Middelburg JJ, Heip C and 5 others (2001) The seafloor as the ultimate sediment trap - using sediment properties to constrain benthic-pelagic exchange processes at the Goban Spur. Deep-Sea Res II 48: 3245-3264

Herndl GJ (1988) Ecology of amorphous aggregations (marine snow) in the Northern Adriatic Sea. II. Microbial density and activity in marine snow and its implication to overall pelagic processes. Mar Ecol Prog Ser 48:265-275
Herndl GJ (1992) Marine snow in the Northern Adriatic Sea: possible causes and consequences for a shallow ecosystem. Mar Microb Food Webs 6:149-172

Herndl GJ, Peduzzi P (1988) The ecology of amorphous aggregations (marine snow) in the northern Adriatic Sea. I. General considerations. PSZN I: Mar Ecol 9:79-90

Hernes PJ, Peterson ML, Murray JW, Wakeham SG, Lee C, Hedges JI (2001) Particulate carbon and nitrogen fluxes and compositions in the central equatorial Pacific. DeepSea Res I 48:1999-2023

Heussner S, Monaco A, Fowler SW (1987) Characterization and vertical transport of settling biogenic particles in the northwestern Mediterranean. Mitt Geol-Paläontol Inst Univ Hamburg 62:127-147

Heussner S, Monaco A, Fowler SW, Buscail R, Millot C, Bojanowski R (1988) ECOMARGE: flux of particulate matter in the northwestern Mediterranean (Golfe du Lion). In: Minas HJ, Nival P (eds) Océanographie pélagique méditerranéenne. Oceanol Acta Spec Issue 9:149-154

Heussner S, Durrieu de Madron X, Radakovitch O, Beaufort L and 5 others (1999) Spatial and temporal patterns of downward particle fluxes on the continental slope of the Bay of Biscay (northeastern Atlantic). Deep-Sea Res II 46: 2101-2146

Hidaka K, Kawaguchi K, Murakami M, Takahashi M (2001) Downward transport of organic carbon by diel migratory micronekton in the western equatorial Pacific: its quantitative and qualitative importance. Deep-Sea Res I 48: 1923-1939

Hill PS, Nowell ARM (1990) The potential of large, fast-sinking particles in the clearing of nepheloid layers. Philos Trans R Soc Lond Ser A 331:103-117

Hinga KR, Sieburth JMN, Heath GR (1979) The supply and use of organic material at the deep-sea floor. J Mar Res 37: $557-579$

Hofmann EE, Klinck JM, Paffenhöfer GA (1981) Concentrations and vertical fluxes of zooplankton fecal pellets on a continental shelf. Mar Biol 327-335

Holloway CF, Cowen JP (1997) Development of a scanning confocal laser microscopic technique to examine the structure and composition of marine snow. Limnol Oceanogr 42:1340-1352

Hong Y, Smith WO Jr, White AM (1997) Studies on transparent exopolymer particles (TEP) produced in the Ross Sea (Antarctica) and by Phaeocystis antarctica (Prymnesiophyceae). J Phycol 33:368-376

Honjo S (1978) Sedimentation of materials in the Sargasso Sea at a 5,367 m deep station. J Mar Res 36:469-492

Honjo S (1980) Material fluxes and modes of sedimentation in the mesopelagic and bathypelagic zones. J Mar Res 38: 53-97

Honjo S (1982) Seasonality and interaction of biogenic and lithogenic particulate flux at the Panama Basin. Science 218:883-884

Honjo S (1997) Particle flux in the World Ocean. Oceanus 40: 2-10

Honjo S, Doherty KW (1988) Large aperture time-series sediment traps; design objectives, construction and application. Deep-Sea Res 35:133-149

Honjo S, Manganini SJ (1993) Annual biogenic particle fluxes to the interior of the North Atlantic Ocean; studied at $34^{\circ} \mathrm{N}$ $21^{\circ} \mathrm{W}$ and $48^{\circ} \mathrm{N} 21^{\circ} \mathrm{W}$. Deep-Sea Res I 40:587-607

Honjo S, Roman MR (1978) Marine copepod fecal pellets: production, preservation, and sedimentation. J Mar Res 36: 45-57

Honjo S, Weller RA (1997) Monsoon winds and carbon cycles in the Arabian Sea. Oceanus 40:24-28 
Honjo S, Connell JF, Sachs PL (1980) Deep-ocean sediment trap: design and function of PARFLUX Mark II. Deep-Sea Res 27:745-753

Honjo S, Manganini SJ, Cole JJ (1982a) Sedimentation of biogenic matter in the deep ocean. Deep-Sea Res 29:609-625

Honjo S, Spencer DW, Farrington JW (1982b) Deep advective transport of lithogenic particles in Panama Basin. Science 216:516-518

Honjo S, Doherty KW, Agrawal YC, Asper VL (1984) Direct optical assessment of large amorphous aggregates (marine snow) in the deep ocean. Deep-Sea Res 31:67-76

Honjo S, Hay BJ, Manganini SJ, Asper VL and 6 others (1987) Seasonal cyclicity of lithogenic particle fluxes at a southern Black Sea sediment trap station. Mitt Geol-Paläont Inst Univ Hamburg 62:19-39

Honjo S, Manganini SJ, Wefer G (1988) Annual particle flux and a winter outburst of sedimentation in the northern Norwegian Sea. Deep-Sea Res 35:1223-1234

Honjo S, Spencer DW, Gardner WD (1992) A sediment trap intercomparison experiment in the Panama Basin, 1979. Deep-Sea Res 39:333-358

Honjo S, Dymond J, Collier R, Manganini SJ (1995) Export production of particles to the interior of the equatorial Pacific Ocean during the 1992 EqPac experiment. DeepSea Res II 42:831-870

Honjo S, Dymond J, Prell W, Ittekkot V (1999) Monsooncontrolled export fluxes to the interior of the Arabian Sea. Deep-Sea Res II 46:1859-1902

Honjo S, Francois R, Manganini S, Dymond J, Collier R (2000) Particle fluxes to the interior of the Southern Ocean in the Western Pacific sector along $170^{\circ} \mathrm{W}$. Deep-Sea Res II 47 : 3521-3548

Hsiao SIC (1987) Sedimentation in Arctic Canada: species composition and biomass of phytoplankton contributed to the marine sediments in Frobisher Bay. Polar Biol 7: $245-251$

Huh CA, Small LF, Niemnil S, Finney BP and 4 others (1990) Sedimentation dynamics in the Santa Monica-San Pedro Basin off Los Angeles: radiochemical, sediment trap and transmissometer studies. Cont Shelf Res 10:137-164

Huskin I, Anadón R, Álvarez-Marqués F, Harris RP (2000) Ingestion, faecal pellet and egg production rates of Calanus helgolandicus feeding coccolithophorid versus non-coccolithophorid diets. J Exp Mar Biol Ecol 248: $239-254$

Inoue N, Nishizawa S, Fukuda M (1955) The perfection of a turbidity meter and the photographic study of suspended matter and plankton in the sea using an undersea observation chamber. In: Proceedings of the UNESCO Symposium on Physical Oceanography, Tokyo, p 53-58

Iseki K (1981) Particulate organic matter transport to the deep sea by salp fecal pellets. Mar Ecol Prog Ser 5:55-60

Iseki K, Whitney F, Wong CS (1980) Biochemical changes of sedimented matter in sediment trap in shallow coastal waters. Bull Plankton Soc Jpn 27:27-36

Ittekkot V, Degens ET, Honjo S (1984) Seasonality in the fluxes of sugars, amino acids, and amino sugars to the deep ocean: Panama Basin. Deep-Sea Res 31:1071-1083

Ittekkot V, Nair RR, Honjo S, Ramaswamy V and 3 others (1991) Enhanced particle fluxes in Bay of Bengal induced by injection of fresh water. Nature 351:385-387

Izdar H, Konuk T, Honjo S, Asper V and 4 others (1984) First data on sediment trap experiment in Black Sea deep water. Naturwissenschaften 71:478

Izdar H, Konuk T, Ittekkot V, Kempe S, Degens ET (1987) Particle flux in the Black Sea: nature of the organic matter. Mitt Geol-Paläontol Inst Univ Hamburg 62:1-18
Jackson GA (2001) Incorporating joint algal and fecal pellet aggregation and resulting flux from the surface mixed layer. Abstracts of papers presented at the American Society of Limnology and Oceanography Meeting, Albuquerque, New Mexico, February 12 to 16, 2001, p 73

Jacobsen TR, Azam F (1984) Role of bacteria in copepod fecal pellet decomposition: colonization, growth rates and mineralization. Bull Mar Sci 35:495-502

Jahnke RA, Reimers CE, Craven DB (1990) Intensification of recycling of organic matter at the sea floor near ocean margins. Nature 348:50-54

Jickells TD, Deuser WG, Knap AH (1984) The sedimentation rates of trace elements in the Sargasso Sea measured by sediment trap. Deep-Sea Res 31:1169-1178

Jickells TD, Newton PP, King P, Lampitt RS, Boutle C (1996) A comparison of sediment trap records of particle fluxes from 19 to $48^{\circ} \mathrm{N}$ in the northeast Atlantic and their relation to surface water productivity. Deep-Sea Res I 43:971-986

Johannes RE (1967) Ecology of organic aggregates in the vicinity of a coral reef. Limnol Oceanogr 12:189-195

Johnson BD (1976). Nonliving organic particle formation from bubble dissolution. Limnol Oceanogr 21:444-446

Johnson BD, Cooke RC (1980) Organic particle and aggregate formation resulting from the dissolution of bubbles in seawater. Limnol Oceanogr 25:653-661

Johnson PW, Xu HS, Sieburth JMN (1982) The utilization of chroococcoid cyanobacteria by marine protozooplankters but not by calanoid copepods. Ann Inst Océanogr Paris 58(Suppl):297-308

Jordan RW, Priddle J, Pudsey CJ, Barker PF, Whitehouse MJ (1991) Unusual diatom layers in Upper Pleistocene sediments from the northern Weddell Sea. Deep-Sea Res 38: 829-843

Jumars PA, Penry DL, Baross JA, Perry MJ, Frost BW (1989) Closing the microbial loop: dissolved carbon pathway to heterotrophic bacteria from incomplete ingestion, digestion and absorption in animals. Deep-Sea Res 36:483-495

Kajihara M (1971) Settling velocity and porosity of large suspended particles. J Oceanogr Soc Jpn 22:158-161

Kajihara M, Morinaga T, Sekine A (1986) Distributions and upward fluxes of particulate matter near bottom in the southeastern Bering Sea shelf. J Oceanogr Soc Jpn 42: 389-401

Kaltenböck E, Herndl GJ (1992) Ecology of amorphous aggregations (marine snow) in the Northern Adriatic Sea. IV. Dissolved nutrients and the autotrophic community associated with marine snow. Mar Ecol Prog Ser 87:147-159

Karl DM, Knauer GA (1984a) Vertical distribution, transport, and exchange of carbon in the northeast Pacific Ocean: evidence for multiple zones of biological activity. DeepSea Res 31:221-243

Karl DM, Knauer GA (1984b) Detritus-microbe interactions in the marine pelagic environment: selected results from the VERTEX experiment. Bull Mar Sci 35:550-565

Karl DM, Knauer GA (1991) Microbial production and particle flux in the upper $350 \mathrm{~m}$ of the Black Sea. Deep-Sea Res 38(Suppl 2):S921-S942

Karl DM, Lukas R (1996) The Hawaii Ocean Time-series (HOT) program: background, rationale and field implementation. Deep-Sea Res II 43:129-156

Karl DM, Tilbrook BD (1994) Production and transport of methane in oceanic particulate organic matter. Nature 368:732-734

Karl DM, Knauer GA, Martin JH, Ward BB (1984) Bacterial chemolithotrophy in the ocean is associated with sinking particles. Nature 309:54-56

Karl DM, Knauer GA, Martin JH (1988) Downward flux of 
particulate organic matter in the ocean: a particle decomposition paradox. Nature 332:438-441

Karl DM, Tilbrook BD, Tien G (1991) Seasonal coupling of organic matter production and particle flux in the western Bransfield Strait, Antarctica. Deep-Sea Res 38:1097-1126

Karl DM, Christian JR, Dore JE, Hebel DV and 3 others (1996) Seasonal and interannual variability in primary production and particle flux at Station ALOHA. Deep-Sea Res II 43:539-568

Karl DM, Letelier R, Tupas L, Dore J, Christian J, Hebel D (1997) The role of nitrogen fixation in biogeochemical cycling in the subtropical North Pacific Ocean. Nature 388:533-538

Karl DM, Bidigare RR, Letelier RM (2001a) Long-term changes in plankton community structure and productivity in the North pacific Subtropical Gyre: the domain shift hypothesis. Deep-Sea Res II 48:1449-1470

Karl DM, Björkman KM, Dore JE, Fujieki L and 4 others (2001b) Ecological nitrogen-to-phosphorus stoichiometry at station ALOHA. Deep-Sea Res II 48:1529-1566

Keck A, Wassmann P (1996) Temporal and spatial patterns of sedimentation in the subarctic fjord Malangen, northern Norway. Sarsia 80:259-276

Kemp AES, Pearce RB, Koizumi I, Pike J, Rance SJ (1999) The role of mat-forming diatoms in the formation of Mediterranean sapropels. Nature 398:57-61

Kemp AES, Pike J, Pearce RB, Lange CB (2000) The 'fall dump' - a new perspective on the role of a 'shade flora' in the annual cycle of diatom production and export flux. Deep-Sea Res II 47:2129-2154

Kempe S, Jennerjahn TC (1988) The vertical particle flux in the northern North Sea, its seasonality and composition. Mitt Geol-Paläontol Inst Univ Hamburg 65:229-268

Kempe S, Nies H (1987) Chernobyl nuclide record from a North Sea sediment trap. Nature 329:828-831

Kempe S, Nies H, Ittekkot V, Degens ET and 7 others (1987) Comparison of Chernobyl nuclide deposition in the Black Sea and in the North Sea. Mitt Geol-Paläontol Inst Univ Hamburg 62:165-178

Kilps JR, Logan BE, Alldredge AL (1994) Fractal dimensions of marine snow determined from image analysis of in situ photographs. Deep-Sea Res I 41:1159-1169

Kincaid E, Thunnel RC, Le J, Lange CB, Weinheimer AL, Reid FMH (2000) Planktonic foraminiferal fluxes in the Santa Barbara Basin: response to seasonal and interannual hydrographic changes. Deep-Sea Res II 47:1157-1176

King AL, Howard WR (2001) Seasonality of foraminiferal flux in sediment traps at Chatham Rise, SW Pacific: implications for paleotemperature estimates. Deep-Sea Res I 48: $1687-1708$

Kiørboe T (1996) Material flux in the water column. Coast Est Stud 52:67-94

Kiørboe T (2000) Colonization of marine snow aggregates by invertebrate zooplankton: abundance, scaling, and possible role. Limnol Oceanogr 45:479-484

Kiørboe T, Hansen JLS (1993) Phytoplankton aggregate formation: observations of patterns and mechanisms of cell sticking and the significance of exopolymeric material. J Plankton Res 15:993-1018

Kiørboe T, Jackson GA (2001) Marine snow, organic solute plumes, and optimal chemosensory behavior of bacteria. Limnol Oceanogr 46:1309-1318

Kiørboe T, Andersen KP, Dam HG (1990) Coagulation efficiency and aggregate formation in marine phytoplankton. Mar Biol 107:235-245

Kiørboe T, Lundsgaard C, Olesen M, Hansen JLS (1994) Aggregation and sedimentation processes during a spring phytoplankton bloom: a field experiment to test coagulation theory. J Mar Res 52:297-323

Kiørboe T, Hansen JLS, Alldredge AL, Jackson GA and 5 others (1996) Sedimentation of phytoplankton during a diatom bloom: rates and mechanisms. J Mar Res 54: $1123-1148$

Kiørboe T, Tiselius P, Mitchell-Innes B, Hansen JLS, Visser AW, Mari X (1998) Intensive aggregate formation with low vertical flux during an upwelling-induced diatom bloom. Limnol Oceanogr 43:104-116

Kitchell JA (1983) Biotic interactions and siliceous marine phytoplankton.: an ecological and evolutionary perspective. In: Teveez JS, McCall PL (eds) Biotic interactions in recent and fossil benthic communities. Plenum, New York, p 285-329

Knap AH, Blinkley KS, Deuser WG (1986) Synthetic organic chemicals in the deep Sargasso Sea. Nature 319:572-574

Knauer G (1991) The analytical determination of mass flux, inorganic and organic carbon and nitrogen flux in rapidly sinking particles collected in sediment traps. In: Marine particles: analysis and characterization, AGU Geophys Monograph, Vol 63. American Geophysics Union, Washington, DC, p 79-82

Knauer GA, Martin JH (1981) Primary production and carbon-nitrogen fluxes in the upper 1,500 $\mathrm{m}$ of the northeast Pacific. Limnol Oceanogr 26:181-186

Knauer GA, Martin JH, Bruland KW (1979) Fluxes of particulate carbon, nitrogen, and phosphorus in the upper water column of the northeast Pacific. Deep-Sea Res 26:97-108

Knauer GA, Hebel D, Cipriano F (1982) Marine snow: major site of primary production in coastal waters. Nature 300 : 630-631

Knauer GA, Karl DM, Martin JH, Hunter CN (1984) In situ effects of selected preservatives on total carbon, nitrogen and metals collected in sediment traps. J Mar Res 42: 445-462

Knauer GA, Redalje DG, Harrison WG, Karl DM (1990) New production at the VERTEX time-series site. Deep-Sea Res 37:1121-1134

Komar PD, Taghon GL (1985) Analyses of the settling velocities of fecal pellets from the subtidal polychaete Amphicteis scaphobranchiata. J Mar Res 43:605-614

Komar PD, Morse AP, Small LF, Fowler SW (1981) An analysis of sinking rates of natural copepod and euphausiid fecal pellets. Limnol Oceanogr 26:172-180

Koning E, Brummer GJ, Van Raaphorst W, Van Bennekom J, Helder W, Van Iperen J (1997) Settling, dissolution and burial of biogenic silica in the sediments off Somalia (northwestern Indian Ocean). Deep-Sea Res II:1341-1360

Kranck K, Milligan T (1980) Macroflocs: production of marine snow in the laboratory. Mar Ecol Prog Ser 3:19-24

Krause M (1981) Vertical distribution of faecal pellets during FLEX '76. Helgol Meeresunters 34:313-327

Krembs C, Engel A (2001) Abundance and variability of microorganisms and transparent exopolymer particles across the ice-water interface of melting first-year sea ice in the Laptev Sea (Arctic). Mar Biol 138:173-185

Krishnaswami S, Baskaran M, Fowler SW, Heyraud M (1985) Comparative role of salps and other zooplankton in the cycling and transport of selected elements and natural radionuclides in Mediterranean waters. Biogeochemistry $1: 353-360$

Kusakabe M, Ku TL, Harada K, Taguchi K, Tsunogai S (1988) Chernobyl radioactivity found in mid-water sediment interceptors in the N. Pacific and Bering Sea. Geophys Res Lett 15:44-47

Kwint RLJ, Irigoien X, Kramer KJM (1996) Copepods and 
DMSP. In: Kiene RP, Visscher PT, Keller MD, Kirst GO (eds) Biological and environmental chemistry of DMSP and related sulfonium compounds. Plenum Press, New York, p 239-252

Lampitt RS (1985) Evidence for the seasonal deposition of detritus to the deep-sea floor and its subsequent resuspension. Deep-Sea Res 32:885-897

Lampitt RS (1990) Directly measured rapid growth of a deepsea barnacle. Nature 345:805-807

Lampitt RS (1992) The contribution of deep-sea macroplankton to organic remineralization: results from sediment trap and zooplankton studies over the Madeira Abyssal Plain. Deep-Sea Res 39:221-233

Lampitt RS, Antia AN (1997) Particle flux in the deep sea: regional characteristics and temporal variability. DeepSea Res I 44:1377-1403

Lampitt RS, Noji T, Bodungen BV (1991) What happens to zooplankton fecal pellets? Implications for material flux. Mar Biol 104:15-23

Lampitt RS, Hillier WR, Challenor PG (1993a) Seasonal and diel variation in the open ocean concentration of marine snow aggregates. Nature 362:737-739

Lampitt RS, Wishner KF, Turley CM, Angel MV (1993b) Marine snow studies in the northeast Atlantic Ocean: distribution, composition and role as a food source for migrating plankton. Mar Biol 116:689-702

Lampitt RS, Raine RCT, Billett DSM, Rice AL (1995) Material supply to the European continental slope: a budget based on benthic oxygen demand and organic supply. Deep-Sea Res I 42:1865-1880

Lampitt RS, Newton PP, Jickells TD, Thomson J, King P (2000) Near-bottom particle flux in the abyssal northeast Atlantic. Deep-Sea Res II 47:2051-2071

Landing WM, Feely RA (1981) The chemistry and vertical flux of particles in the northeastern Gulf of Alaska. Deep-Sea Res 28:19-37

Landry MR, Peterson WK, Andrews CC (1992) Particulate flux in the water column overlying Santa Monica Basin. Prog Oceanogr 30:167-195

Landry MR, Peterson WK, Fagerness VL (1994a) Mesozooplankton grazing in the Southern California Bight. I. Population abundances and gut pigment contents. Mar Ecol Prog Ser 115:55-71

Landry MR, Lorenzen CJ, Peterson WK (1994b) Mesozooplankton grazing in the Southern California Bight. II. Grazing impact and particulate flux. Mar Ecol Prog Ser 115:73-85

Landry MR, Peterson WK, Lorenzen CJ (1995) Zooplankton grazing, phytoplankton growth, and export flux: inferences from chlorophyll tracer methods. ICES J Mar Sci 52: 337-345

Lane PVZ, Smith SL, Urban JL, Biscayn PE (1994) Carbon flux and recycling associated with zooplanktonic fecal pellets on the shelf of the Middle Atlantic Bight. Deep-Sea Res II 41:437-457

Larrance JD, Chester AJ, Milburn HB (1979) A new sediment trap and particulate flux measurements in lower Cook Inlet, Alaska. Mar Sci Comm 5:269-282

Larson ET, Shanks AL (1996) Consumption of marine snow by two species of juvenile mullet and its contribution to their growth. Mar Ecol Prog Ser 130:19-28

Larsson U, Blomqvist S, Abrahamsson B (1986) A new sediment trap system. Mar Ecol Prog Ser 31:205-207

Lauerman LML, Kaufmann RS (1998) Deep-sea epibenthic echinoderms and a temporally varying food supply: results from a one year time series in the N.E. Pacific. Deep-Sea Res II 45:817-842
Lawrence SG, Ahmad A, Azam F (1993) Fate of particlebound bacteria ingested by Calanus pacificus. Mar Ecol Prog Ser 97:299-307

Laws EA, Bienfang PK, Ziemann DA, Conquest LD (1988) Phytoplankton population dynamics and the fate of production during the spring bloom in Auke Bay, Alaska. Limnol Oceanogr 33:57-65

Laws EA, DiTullio GR, Betzer PR, Karl DM, Carder KL (1989) Autotrophic production and elemental fluxes at $26^{\circ} \mathrm{N}$, $155^{\circ} \mathrm{W}$ in the North Pacific subtropical gyre. Deep-Sea Res 36:103-120

Lazzari AD, Boldrin A, Rabitti S, Turchetto MM (1998) Variability of downward fluxes of particulate matter in the Otranto Straight area. J Mar Syst 20:399-413

Lee BG, Fisher NS (1992) Decomposition and release of elements from zooplannkton debris. Mar Ecol Prog Ser 88: $117-128$

Lee BG, Fisher NS (1994) Effects of sinking and zooplankton grazing on the release of elements from planktonic debris. Mar Ecol Prog Ser 110:271-281

Lee C, Cronin C (1982) The vertical flux of particulate organic nitrogen in the sea: decomposition of amino acids in the Peru upwelling area and the equatorial Atlantic. J Mar Res 40:227-251

Lee C, Cronin C (1984) Particulate amino acids in the sea: effects of primary productivity and biological decomposition. J Mar Res 42:1075-1097

Lee C, Wakeham SG, Farrington JW (1983) Variations in the composition of particulate organic matter in a time-series sediment trap. Mar Chem 13:181-194

Lee C, Wakeham SG, Hedges JI (1988) The measurement of oceanic particle flux - are 'swimmers' a problem? Oceanography 1:34-36

Lee C, Hedges JI, Wakeham SG, Zhu N (1992) Effectiveness of various treatments in retarding microbial activity in sediment trap material and their effects on the collection of swimmers. Limnol Oceanogr 37:117-130

Lee C, Murray DW, Barber RT, Buesseler KO and 9 others (1998) Particulate organic carbon fluxes: compilation of results from the 1995 US JGOFS Arabian Sea Process Study. Deep-Sea Res II 45:2489-2501

Legendre L, Gosselin M (1989) New production and export of organic matter to the deep ocean: consequences of some recent discoveries. Limnol Oceanogr 34:1374-1380

Legendre L, Le Fèvre J (1995) Microbial food webs and the export of biogenic carbon in oceans. Aquat Microb Ecol 9: $69-77$

Legendre L, Michaud J (1998) Flux of biogenic carbon in oceans: size-dependent regulation by pelagic food webs. Mar Ecol Prog Ser 164:1-11

Legendre L, Rassoulzadegan F (1996) Food-web mediated export of biogenic carbon in oceans: hydrodynamic control. Mar Ecol Prog Ser 145:179-193

Lenz J, Morales A, Gunkel J (1993) Mesozooplankton standing stock during the North Atlantic spring bloom study in 1989 and its potential grazing pressure on phytoplankton: a comparison between low, medium and high latitudes. Deep-Sea Res II 40:559-572

Leppard GG, Heissenberger A, Herndl GJ (1996) Ultrastructure of marine snow. I. Transmission electron microscopy methodology. Mar Ecol Prog Ser 135:289-298

Leppard GG, West MM, Flannigan DT, Carson J, Lott JNA (1997) A classification scheme for marine organic colloids in the Adriatic Sea: colloid speciation by transmission electron microscopy. Can J Fish Aquat Sci 54: $2334-2349$

Leventer A (1991) Sediment trap diatom assemblages from 
the northern Antarctic Peninsula region. Deep-Sea Res 38: $1127-1143$

Liebezeit G (1987) Early diagenesis of carbohydrates in the marine environment. I. Sediment trap experiments. Mitt Geol-Paläontol Inst Univ Hamburg 62:279-299

Livingston HD, Anderson RF (1983) Large particle transport of plutonium and other fallout radionuclides to the deep ocean. Nature 303:228-231

Lochte K, Turley CM (1988) Bacteria and cyanobacteria associated with phytodetritus in the deep sea. Nature 333: 67-69

Lochte K, Ducklow HW, Fasham MJR, Steinen C (1993) Plankton succession and carbon cycling at $47^{\circ} \mathrm{N} 20^{\circ} \mathrm{W}$ during the JGOFS North Atlantic bloom experiment. Deep-Sea Res II 40:91-114

Logan BE, Alldredge AL (1989) Potential for increased nutrient uptake by flocculating diatoms. Mar Biol 101:443-450

Logan BE, Passow U, Alldredge AL, Grossart HP, Simon M (1995) Rapid formation and sedimentation of large aggregates is predictable from coagulation rates (half lives) of transparent exopolymer particles (TEP). Deep-Sea Res 42: 203-214

Logan GA, Hayes JM, Hieshima GB, Summons RE (1995) Terminal Proterozoic reorganization of biogeochemical cycles. Nature 376:53-56

Loh AN, Bauer JE (2000) Distribution, partitioning and fluxes of dissolved and particulate organic $\mathrm{C}, \mathrm{N}$ and $\mathrm{P}$ in the eastern North Pacific and Southern Oceans. Deep-Sea Res I 47:2287-2316

Lohrenz SE, Knauer GA, Asper VL, Tuel M, Michaels AF, Knap AH (1992) Seasonal variability in primary production and particle flux in the northwestern Sargasso Sea: U.S. JGOFS Bermuda Atlantic time-series study. DeepSea Res 39:1373-1391

Long RA, Azam F (1996) Abundant protein-containing particles in the sea. Aquat Microb Ecol 10:213-221

Longhurst AR (1991) Role of the marine biosphere in the global carbon cycle. Limnol Oceanogr 36:1507-1526

Longhurst AR (2000) Review of Hanson RB, Ducklow HW, Field JG (eds) (1997) The changing ocean carbon cyclea midterm synthesis of the Joint Global Ocean Flux Study. Limnol Oceanogr 45:1446-1447

Longhurst AR, Harrison WG (1988) Vertical nitrogen flux from the oceanic photic zone by diel migrant zooplankton and nekton. Deep-Sea Res 35:881-890

Longhurst AR, Harrison WG (1989) The biological pump: profiles of plankton production and consumption in the ocean. Prog Oceanogr 22:47-123

Longhurst AR, Williams R (1992) Carbon flux by seasonal migrant copepods is a small number. J Plankton Res 14: 1495-1509

Longhurst AR, Bedo A, Harrison WG, Head EJH and 3 others (1989) NFLUX: a test of vertical nitrogen flux by diel migrant biota. Deep-Sea Res 36:1705-1719

Longhurst AR, Bedo A, Harrison WG, Head EJH, Sameoto DD (1990) Vertical flux of respiratory carbon by oceanic diel migrant biota. Deep-Sea Res 37:685-694

Lorenzen CJ, Welschmeyer NA (1983) The in situ sinking rates of herbivore fecal pellets. J Plankton Res 5:929-933

Lorenzen CJ, Shuman FR, Bennet JT (1981) In situ calibration of a sediment trap. Limnol Oceanogr 26:580-585

Lorenzen CJ, Welschmeyer NA, Copping AE (1983a) Particulate organic carbon flux in the subarctic Pacific. Deep-Sea Res 30:639-643

Lorenzen CJ, Welschmeyer NA, Copping AE, Vernet $M$ (1983b) Sinking rates of organic particles. Limnol Oceanogr 28:766-769
Lundsgaard C, Olesen M (1997) The origin of sedimenting detrital matter in a coastal system. Limnol Oceanogr 42: 1001-1005

Luo S, Ku TL, Kusakabe M, Bishop JKB, Yang YL (1995) Tracing particle cycling in the upper ocean with ${ }^{230} \mathrm{Th}$ and ${ }^{228}$ Th: an investigation in the equatorial Pacific along $140^{\circ}$ W. Deep-Sea Res II 42:805-829

Lutter S, Taasen JP, Hopkins CCE, Smetacek V (1989) Phytoplankton dynamics and sedimentation processes during spring and summer in Balsfjord, northern Norway. Polar Biol 10:113-124

MacIntyre S, Alldredge AL, Gotschalk CC (1995) Accumulation of marine snow at density discontinuities in the water column. Limnol Oceanogr 40:449-468

Madin LP (1982) Production, composition and sedimentation of salp fecal pellets in oceanic waters. Mar Biol 67:39-45

Madin LP, Purcell J, Miller CA (1997) Abundance and grazing effects of Cyclosalpa bakeri in the subarctic Pacific. Mar Ecol Prog Ser 157:175-183

Maita Y, Odate T, Yanada M (1988) Vertical transport of organic carbon by sinking particles and the role of zooand phytogenic matters in neritic waters. Bull Fac Fish Hokkaido Univ 39:265-274

Mari X, Kiørboe T (1996) Abundance, size distribution and bacterial colonization of transparent exopolymeric particles (TEP) during spring in the Kattegat. J Plankton Res 18:969-986

Martens P, Krause M (1990) The fate of faecal pellets in the North Sea. Helgol Meeresunters 44:9-19

Martin JH, Knauer GA, Karl DM, Broenkow WW (1987) VERTEX: carbon cycling in the northeast Pacific. Deep-Sea Res 34:267-285

Martin JH, Fitzwater SE, Gordon RM, Hunter CN, Tanner SJ (1993) Iron, primary production and carbon-nitrogen flux studies during the JGOFS North Atlantic Bloom Experiment. Deep-Sea Res II 40:115-134

Marty JC, Nicolas E, Miquel JC, Fowler SW (1994) Particulate fluxes of organic compounds and their relationship to zooplankton fecal pellets in the northwestern Mediterranean Sea. Mar Chem 46:387-405

Matsueda H, Handa N (1986) Vertical flux of hydrocarbons as measured in sediment traps in the eastern North Pacific Ocean. Mar Chem 20:179-195

Matsueda H, Handa N, Inoue I, Takano H (1986) Ecological significance of salp fecal pellets collected by sediment traps in the eastern North Pacific. Mar Biol 91:421-431

McCave IN, Hall IR, Antia AN, Chou L and 5 others (2001) Distribution, composition and flux of particulate material over the European margin at $47^{\circ}-50^{\circ} \mathrm{N}$. Deep-Sea Res II 48:3107-3139

McGillicuddy DJ, Robinson AR (1997) Eddy-induced nutrient supply and new production in the Sargasso Sea. Deep-Sea Res 44:1427-1450

McLeroy-Etheridge SL, McManus GB (1999) Food type and concentration affect chlorophyll and carotenoid destruction during copepod feeding. Limnol Oceanogr 44: 2005-2011

Meinecke G, Wefer G (1990) Seasonal pteropod sedimentation in the Norwegian Sea. Palaeogeogr Palaeoclimatol Palaeoecol 79:129-147

Menzel DW (1966). Bubbling of seawater and the production of organic particles: a re-evaluation. Deep-Sea Res 13: 963-966

Michaelis W, Schümann P, Ittekkot V, Konuk T (1987) Sterol markers for organic matter fluxes in the Black Sea. Mitt Geol-Paläontol Inst Univ Hamburg 62:89-98

Michaels AF, Knap AH (1996) Overview of the U.S. JGOFS 
Bermuda Atlantic Time-series Study and the Hydrostation S program. Deep-Sea Res 43:157-198

Michaels AF, Silver MW (1988) Primary production, sinking fluxes and the microbial food web. Deep-Sea Res 35: $473-490$

Michaels AF, Silver MW, Gowing MM, Knauer GA (1990) Cryptic zooplankton 'swimmers' in upper ocean sediment traps. Deep-Sea Res 37:1285-1296

Michaels AF, Bates NR, Buesseler KO, Carlson CA, Knapp AH (1994a) Carbon-cycle imbalances in the Sargasso Sea. Nature 372:537-540

Michaels AF, Knap AH, Dow RL, Gundersen K and 8 others (1994b) Seasonal patterns of ocean biogeochemistry at the U.S. JGOFS Bermuda Atlantic Time-series Study site. Deep-Sea Res I 41:1013-1038

Miquel JC, Fowler SW, La Rosa J (1993) Vertical particle fluxes in the Ligurian Sea. Ann Inst Oceanogr 69:107-110

Miquel JC, Fowler SW, La Rosa J, Buat-Menare P (1994) Dynamics of the downward flux of particles and carbon in the open northwestern Mediterranean Sea. Deep-Sea Res I 41:243-261

Monaco A, Biscaye P, Soyer J, Pocklington R, Heussner S (1990a) Particle fluxes and ecosystem response on a continental margin: the 1985-1988 Mediterranean ECOMARGE experiment. Cont Shelf Res 10:809-839

Monaco A, Courp T, Heussner S, Carbonne J, Fowler SJ, Deniaux B (1990b) Seasonality and composition of particulate fluxes during ECOMARGE-I, western Gulf of Lions. Cont Shelf Res 10:959-987

Montgomery MT, Welschmeyer NA, Kirchman DL (1990) A simple assay for chitin: application to sediment trap samples from the subarctic Pacific. Mar Ecol Prog Ser 64: 301-308

Moore HB (1931) The muds of the Clyde Sea Area. III. Chemical and physical conditions; rate and nature of sedimentation; and fauna. J Mar Biol Assoc UK 17:325-358

Moore WS, Dymond J (1988) Correlation of ${ }^{210} \mathrm{~Pb}$ removal with organic carbon fluxes in the Pacific Ocean. Nature 331:339-341

Morales CE (1987) Carbon and nitrogen content of copepod faecal pellets: effect of food concentration and feeding behavior. Mar Ecol Prog Ser 36:107-114

Morris RJ, Bone Q, Head R, Braconnot JC, Nival P (1988) Role of salps in the flux of organic matter to the bottom of the Ligurian Sea. Mar Biol 97:237-241

Müller PJ, Fischer G (2001) A 4-year sediment trap record of alkenones from the filamentous upwelling region off Cape Blanc, NW Africa and a comparison with distributions in underlying sediments. Deep-Sea Res I 48:1877-1903

Müller PJ, Suess E, Ungerer CA (1986) Amino acids and amino sugars of surface particulate and sediment trap material from waters of the Scotia Sea. Deep-Sea Res 33: 819-838

Müller-Niklas G, Herndl GJ (1992) Activity of fecal coliform bacteria measured by 4 -methylumbelliferyl- $\beta$-D-glucuronide substrate in the northern Adriatic Sea with special reference to marine snow. Mar Ecol Prog Ser 89:305-309

Murphy K, Dymond J (1984) Rare earth element fluxes and geochemical budget in the eastern equatorial Pacific. Nature 307:444-447

Murray JW, Young J, Newton J, Dunne J and 3 others (1996) Export flux of particulate organic carbon from the central equatorial Pacific determined using a combined trap- ${ }^{234} \mathrm{Th}$ approach. Deep-Sea Res II 43:1095-1132

Naes K, Skei JM, Wassmann P (1988) Total particulate and organic fluxes in anoxic Framvaren waters. Mar Chem 23: $257-268$
Nagasawa S, Nemoto T (1988) Presence of bacteria in guts of marine crustaceans and on their fecal pellets. J Plankton Res 10:559-564

Nair R, Ittekkot V, Manganini S, Ramaswamy V and 4 others (1989) Increased particle flux to the deep ocean related to monsoons. Nature 338:749-751

Najdek M (1996) Fatty acid composition in amorphous aggregates in the northern Adriatic Sea. Mar Ecol Prog Ser 139: 219-226

Neale AC, Prahl FG, Eglinton G, O'Hara SCM, Corner EDS (1986) Lipid changes during a planktonic feeding sequence involving unicellular algae, Eliminus nauplii and adult Calanus. J Mar Biol Assoc UK 66:1-13

Nejstgaard JC, Gismervik I, Solberg PT (1997) Feeding and reproduction by Calanus finmarchicus, and microzooplankton grazing during mesocosm blooms of diatoms and the coccolithophore Emiliania huxleyi. Mar Ecol Prog Ser 147:197-217

Nelson JR (1989) Phytoplankton pigments in macrozooplankton feces: variability in carotenoid alterations. Mar Ecol Prog Ser 52:129-144

Nelson JR, Beers JR, Eppley RW, Jackson GA, McCarthy JJ, Soutar A (1987) A particle flux study in the Santa MonicaSan Pedro Basin off Los Angeles: particle flux, primary production, and transmissometer survey. Cont Shelf Res 7: 307-328

Nicolaisen W, Christensen H (1986) Pelagic turnover and transport to the bottom of particulate organic material in the northern Øresund. Ophelia 26:317-332

Nishizawa S (1966) Suspended material in the sea: from detritus to symbiotic microcosmos. Bull Plankton Soc Jpn 13: $1-33$

Nishizawa S (1969) Suspended material in the sea. II. Re-evaluation of the hypotheses. Bull Plankton Soc Jpn 16:1-42

Nishizawa S, Fukuda M, Inoue N (1954) Photographic study of suspended matter and plankton in the sea. Bull Fac Fish Hokkaido Univ 5:36-40

Nodder SC, Waite AM (2001) Is Southern Ocean organic carbon and biogenic silica export enhanced by iron-stimulated increases in biological production? Sediment trap results from SOIREE. Deep-Sea Res II 48:2681-2701

Nodder SD, Northcote LC (2001) Episodic particulate fluxes at southern temperate mid-latitudes $\left(42-45^{\circ} \mathrm{S}\right)$ in the Subtropical Front region, east of New Zealand. Deep-Sea Res I 48:833-864

Noji TT (1991) The influence of macrozooplankton on vertical particulate flux. Sarsia 76:1-9

Noji T, Passow U, Smetacek V (1986) Interaction between pelagial and benthal during autumn in Kiel Bight. I. Development and sedimentation of phytoplankton blooms. Ophelia 26:333-349

Noji TT, Estep KW, MacIntyre F, Norrbin F (1991) Image analysis of faecal material grazed upon by three species of copepods: evidence for coprorhexy, coprophagy and coprochaly. J Mar Biol Assoc UK 71:465-480

Noji TT, Noji CIM, Barthel KG (1993) Pelagic-benthic coupling during the onset of winter in a northern Norwegian fjord. Carbon flow and fate of suspended particulate matter. Mar Ecol Prog Ser 93:89-99

Noji TT, Bathmann UV, Bodungen BV, Voss M and 6 others (1997) Clearance of picoplankton-sized particles and formation of rapidly sinking aggregates by the pteropod Limacina retroversa. J Plankton Res 19:863-875

Noji TT, Børsheim KY, Rey F, Nortvedt R (1999a) Dissolved organic carbon associated with sinking particles can be crucial for estimates of vertical carbon flux. Sarsia 84: $129-135$ 
Noji TT, Rey F, Miller LA, Børsheim KY, Urban-Rich J (1999b) Fate of biogenic carbon in the upper $200 \mathrm{~m}$ of the central Greenland Sea. Deep-Sea Res II 46:1497-1509

Noriki S, Tsunogai S (1986) Particulate fluxes and major components of settling particles from sediment trap experiments in the Pacific Ocean. Deep-Sea Res 33:903-912

Noriki S, Ishimori N, Tsunogai S (1985a) Regeneration of chemical elements from settling particles collected by sediment trap in Funka Bay, Japan. J Oceanogr Soc Jpn 41:113-120

Noriki S, Ishimori N, Harada K, Tsunogai S (1985b) Removal of trace metals from seawater during a phytoplankton bloom as studied with sediment traps in Funka Bay, Japan. Mar Chem 17:75-89

Nöthig EM, Bodungen BV (1989) Occurrence and vertical flux of faecal pellets of probably protozoan origin in the southeastern Weddell Sea (Antarctica). Mar Ecol Prog Ser 56:281-289

Nott JA, Nicolaidou A (1996) Kinetics of metals in molluscan faecal pellets and mineralized granules, incubated in marine sediments. J Exp Mar Biol Ecol 197:203-218

Nott JA, Corner EDS, Mavin LJ, O'Hara SCM (1985) Cyclical contributions of the digestive epithelium to faecal pellet formation by the copepod Calanus helgolandicus. Mar Biol 89:271-279

Novitsky JA (1990) Evidence for sedimenting particles as the origin of the microbial community in a coastal marine sediment. Mar Ecol Prog Ser 60:161-167

O'Brien DP (1987) Direct observations of the behaviour of Euphausia superba and Euphausia crystallorophias (Crustacea: Euphausiacea) under pack ice during the Antarctic spring of 1985. J Crust Biol 7:437-448.

Ogawa K (1977) Primary participation of fecal bacteria in the formation of suspended organic matter in the sea. II. Floc formation by fecal bacteria isolated from marine animals. Bull Jpn Soc Sci Fish 43:1089-1096

Ohtsuka S, Kubo N (1991) Larvaceans and their houses as important food for some pelagic copepods. Proceedings of the Fourth International Conference on Copepoda. Bull Plankton Soc Jpn Spec Vol, p 535-551

Olesen M (2001) How small vertical loss rates can lead to exceptional high primary production in a stratified coastal system. Abstracts of papers presented at the American Society of Limnology and Oceanography Meeting, Albuquerque, New Mexico, February 12 to 16, 2001, p 106

Oliwenstein L (1996) Life's grand explosions. Discover 17: $42-43$

Osinga R, Kwint RLJ, Lewis WE, Kraaay GW and 3 others (1996) Production and fate of dimethylsulfide and dimethylsulfoniopropionate in pealgic mesocosms: the role of sedimentation. Mar Ecol Prog Ser 131:275-286

Osterroht C, Smetacek V (1980) Vertical transport of chlorinated hydrocarbons by sedimentation of particulate matter in Kiel Bight. Mar Ecol Prog Ser 2:27-34

Otsuki A, Kaneda Y, Hashimoto S (1993) Identification and significance of pyrochlorins in fecal pellets of the marine malacostracan crustaceans Heptacarpus rectirostris and Palaemon pacificus. Mar Biol 115:463-467

Paffenhöfer GA (1994) Variability due to feeding activity of individual copepods. J Plankton Res 16:617-626

Paffenhöfer GA, Knowles SC (1979) Ecological implications of fecal pellet size, production and consumption by copepods. J Mar Res 37:35-49

Parker GM (1984) Dispersal of zooxanthellae on coral reefs by predators on cnidarians. Biol Bull 167:159-167

Passow U (2000) Formation of transparent exopolymer particles TEP, from dissolved precursor material. Mar Ecol Prog Ser 192:1-11
Passow U, Alldredge AL (1994) Distribution, size and bacterial colonization of transparent exopolymer particles (TEP) in the ocean. Mar Ecol Prog Ser 113:185-198

Passow U, Alldredge AL (1995) Aggregation of a diatom bloom in a mesocosm: the role of transparent exopolymer particles (TEP). Deep-Sea Res II 42:99-109

Passow U, Alldredge AL (1999) Do transparent exopolymer particles (TEP) inhibit grazing by the euphausiid Euphausia pacifica? J Plankton Res 21:2203-2217

Passow U, Peinert R (1993) The role of plankton in particle flux: two case studies from the northeast Atlantic. DeepSea Res II 40:573-585

Passow U, Wassmann P (1994) On the trophic fate of Phaeocystis pouchetii (Hariot): IV. The formation of marine snow by P. pouchetii. Mar Ecol Prog Ser 104:153-161

Passow U, Peinert R, Zeitzschel B (1993) Distribution and sedimentation of organic matter during the inter-monsoon period off Oman (West Arabian Sea). Deep-Sea Res II 40: 833-849

Passow U, Alldredge AL, Logan BE (1994) The role of particulate carbohydrate exudates in the flocculation of diatom blooms. Deep-Sea Res I 41:335-357

Passow U, Shipe RF, Murray A, Pak DK, Brzezinski MA, Alldredge AL (2001) The origin of transparent exopolymer particles (TEP) and their role in the sedimentation of particulate matter. Cont Shelf Res 21:327-346

Pasternak A, Arashkevich E, Riser CW, Ratkova T, Wassmann $P$ (2000). Seasonal variation in zooplankton and suspended faecal pellets in the subarctic Norwegian Balsfjorden, in 1996. Sarsia 85:439-452.

Pedros-Alio C, Mas J, Gasol JM, Guererro R (1989) Sinking speeds of free-living phototrophic bacteria determined with covered and uncovered sediment traps. J Plankton Res 11:887-905

Peduzzi P, Herndl GJ (1986) Role of bacteria in decomposition of faecal pellets egested by the epiphyte-grazing gastropod Gibbula umbilicaris. Mar Biol 92:417-424

Peinert R (1986) Production, grazing and sedimentation in the Norwegian Coastal Current. In: Skreslet S (ed) The role of freshwater outflow in coastal marine ecosystems. NATO ASI Series, Vol G7. Springer-Verlag, Berlin, p 361-374

Peinert R, Miquel JC (1994) The significance of frontal processes for vertical particle fluxes: a case study in the Alboran Sea (SW Mediterranean Sea). J Mar Syst 5:377-389

Peinert R, Saure A, Stegmann P, Stienen C, Haardt H, Smetacek V (1982) Dynamics of primary production and sedimentation in a coastal ecosystem. Neth J Sea Res 16: 276-289

Peinert R, Bathmann U, Bodungen BV, Noji T (1987) The impact of grazing on spring phytoplankton growth and sedimentation in the Norwegian Current. Mitt GeolPaläontol Inst Univ Hamburg 62:149-164

Peinert R, Bodungen BV, Smetacek VS (1989) Food web structure and loss rate. In: Berger WH, Smetacek VS, Wefer G (eds) Productivity of the ocean: present and past. John Wiley \& Sons, Chichester, p 35-48

Peña MA, Denman KL, Calvert SE, Thomson RE, Forbes JR (1999) The seasonal cycle in sinking particle fluxes off Vancouver Island, British Columbia. Deep-Sea Res II 46: 2969-2992

Perissinotto R, Pakhomov EA (1998) Contribution of salps to carbon flux of marginal ice zone of the Lazarev Sea, Southern Ocean. Mar Biol 131:25-32

Peterson W, Dam HG (1990) The influence of copepod 'swimmers' on pigment fluxes in brine-filled vs. ambient seawater-filled sediment traps. Limnol Oceanogr 35:448-455

Pfannkuche O (1993) Benthic response to the sedimentation 
of particulate organic matter at the BIOTRANS station, $47^{\circ} \mathrm{N}, 20^{\circ} \mathrm{W}$. Deep-Sea Res II 40:135-149

Pfannkuche O, Lochte K (1993) Open ocean pelago-benthic coupling: cyanobacteria as tracers of sedimenting salp feces. Deep-Sea Res I 40:727-737

Pfannkuche O, Boetius A, Lochte K, Lundgreen U, Thiel H (1999) Responses of deep-sea benthos to sedimentation patterns in the North-East Atlantic in 1992. Deep-Sea Res I 46:573-596

Pilskaln CH (1991) Biogenic aggregate sedimentation in the Black Sea Basin. In: Izdar E, Murray JW (eds), Black Sea oceanography. Kluwer Academic Publishers, Dordrecht, p 293-306

Pilskaln CH, Honjo S (1987) The fecal pellet fraction of biogeochemical particle fluxes to the deep sea. Global Biogeochem Cycles 1:31-48

Pilskaln CH, Paduan JB, Chavez FP, Anderson RY, Berelson WM (1996) Carbon export and regeneration in the coastal upwelling system of Monterey Bay, central California. J Mar Res 54:1149-1178

Pilskaln CH, Lehmann C, Paduan JB, Silver MW (1998) Spatial and temporal dynamics in marine aggregate abundance, sinking rate and flux: Monterey Bay, central California. Deep-Sea Res II 45:1803-1837

Pisias NG, Murray DW, Roelofs AK (1986) Radiolarian and silicoflagellate response to oceanographic changes associated with the 1983 El Niño. Nature 320:259-262

Platt T, Subba Rao DV, Smith JC, Li WK and 3 others (1983) Photosynthetically-competent phytoplankton from the aphotic zone of the deep ocean. Mar Ecol Prog Ser 10: 105-110

Ploug H, Grossart HP (2000) Bacterial growth and grazing on diatom aggregates: respiratory carbon turnover as a function of aggregate size and sinking velocity. Limnol Oceanogr 45:1467-1475

Ploug H, Jørgensen BB (1999) A net-jet flow system for mass transfer and microsensor studies of sinking aggregates. Mar Ecol Prog Ser 176:279-290

Ploug H, Grossart HP, Azam F, Jørgensen BB (1999) Photosynthesis, respiration, and carbon turnover in sinking marine snow from surface waters of Southern California Bight: implications for the carbon cycle in the ocean. Mar Ecol Prog Ser 179:1-11

Pomeroy LR, Deibel D (1980) Aggregation of organic matter by pelagic tunicates. Limnol Oceanogr 25:643-652

Pomeroy LR, Hanson RB, McGillivary PA, Sherr BF, Kirchman K, Deibel D (1984) Microbiology and chemistry of fecal products of pelagic tunicates: rates and fates. Bull Mar Sci 35:426-439

Porter KG, Robbins EI (1981) Zooplankton fecal pellets link fossil fuel and phosphate deposits. Science 212:931-933

Posedel N, Faganeli J (1991) Nature and sedimentation of suspended particulate matter during density stratification in shallow coastal waters (Gulf of Trieste, northern Adriatic). Mar Ecol Prog Ser 77:135-145

Poulet SA, Harris RP, Martin-Jezequel V, Moal J, Samian JF (1986) Free amino acids in copepod faecal pellets. Oceanol Acta 9:191-197

Prahl FG, Carpenter R (1979) The role of zooplankton fecal pellets in the sedimentation of polycyclic aromatic hydrocarbons in Dabob Bay, Washington. Geochim Cosmochim Acta 43:1959-1972

Prahl FG, Eglinton G, Corner EDS, O'Hara SCM (1984a) Copepod fecal pellets as a source of dihydrophytol in marine sediments. Science 224:1235-1237

Prahl FG, Eglinton G, Corner EDS, O'Hara SCM, Forsberg TEV (1984b) Changes in plant lipids during passage through the gut of Calanus. J Mar Biol Assoc UK 64: 317-334

Prahl FG, Eglinton G, Corner EDS, O'Hara SCM (1985) Faecal lipids released by fish feeding on zooplankton. J Mar Biol Assoc UK 65:547-560

Prahl FG, Dymond J, Sparrow MA (2000) Annual biomarker record for export production in the central Arabian Sea. Deep-Sea Res II 47:1581-1604

Prahl FG, Pilskaln CH, Sparrow MA (2001) Seasonal record for alkenones in sedimentary particles from the Gulf of Maine. Deep-Sea Res I 48:515-528

Prézelin BB, Alldredge AL (1983) Primary production of marine snow during and after an upwelling event. Limnol Oceanogr 28:1156-1167

Proctor LM, Fuhrman JA (1991) Roles of viral infection in organic particle flux. Mar Ecol Prog Ser 69:133-142

Puàkarić S, Fowler SW, Miquel JC (1992) Temporal changes in particulate flux in the northern Adriatic Sea. Est Coast Shelf Sci 35:267-287

Radakovitch O, Heussner S (1999) Fluxes and budget of ${ }^{210} \mathrm{~Pb}$ on the continental margin of the Bay of Biscay (northeastern Atlantic). Deep-Sea Res II 46:2175-2203

Raghukumar S, Raghukumar C (1999) Thraustochytrid fungoid protists in faecal pellets of the tunicate Pegea confoederata, their tolerance to deep-sea conditions and implication in degradation processes. Mar Ecol Prog Ser 190:133-140

Ramaiah N, Yoshikawa T, Furuya K (2001) Temporal variations in transparent exopolymer particles (TEP) associated with a diatom spring bloom in a subarctic ria in Japan. Mar Ecol Prog Ser 212:79-88

Rath J, Wu KY, Herndl GJ, DeLong EF (1998) High phylogenetic diversity in a marine-snow-associated bacterial assemblage. Aquat Microb Ecol 14:261-269

Rau GH, Takahashi T, Des Marais DJ, Repeta DJ, Martin JH (1992) The relationship between $\delta^{13} \mathrm{C}$ of organic matter and $\left[\mathrm{CO}_{2}(\mathrm{aq})\right]$ in ocean surface water: data from a JGOFS site in the northeast Atlantic and a model. Geochim Cosmochim Acta 56:1413-1419

Reemtsma T, Haake B, Ittekkot V, Nair RR, Brockmann UH (1990) Downward flux of particulate fatty acids in the central Arabian Sea. Mar Chem 29:183-202

Rehbock PF (1975) Huxley, Haeckel, and the oceanographers: the case of Bathybius haeckelii. Isis 66:504-533

Reigstad M, Wassmann P (1996) Importance of advection for pelagic-benthic coupling in north Norwegian fjords. Sarsia 80:245-257

Reigstad M, Wassmann P, Ratkova T, Arashkevich E, Pasternak A, Øygarden S (2000) Comparison of the springtime vertical export of biogenic matter in three northern Norwegian fjords. Mar Ecol Prog Ser 201:73-89

Reimers CE, Jahnke RA, McCorkle DC (1992) Carbon fluxes and burial rates over the continental slope and rise off central California with implications for the global carbon cycle. Global Biogeochem Cycles 6:199-224

Reinfelder JR, Fisher NS (1991) The assimilation of elements ingested by marine copepods. Science 251:794-796

Reinfelder JR, Fisher NS, Fowler SW, Teyssie JL (1993) Release rates of trace elements and protein from decomposing planktonic debris. 2. Copepod carcasses and sediment trap particulate matter. J Mar Res 51:423-442

Repeta DJ, Gagosian RB (1982) Carotenoid transformations in coastal marine waters. Nature 295:51-54

Repeta DJ, Gagosian RB (1984) Transformation reactions and recycling of carotenoids and chlorins in the Peru upwelling region $\left(15^{\circ} \mathrm{S}, 75^{\circ} \mathrm{W}\right)$. Geochim Cosmochim Acta 48:1265-1277 
Rey C, Carlotti F, Tande K, Hygum BH (1999) Egg and faecal pellet production of Calanus finmarchicus females from controlled mesocosms and in situ populations: influence of age and feeding history. Mar Ecol Prog Ser 188:133-148

Rey F, Skjoldal HR (1987) Consumption of silicic acid below the euphotic zone by sedimenting diatom blooms in the Barents Sea. Mar Ecol Prog Ser 36:307-312

Rice AL (1983) Thomas Henry Huxley and the strange case of Bathybius haeckelli; a possible alternative explanation. Arch Nat Hist II:169-180

Rice AL, Billett DSM, Fry J, John AWG and 3 others (1986) Seasonal deposition of phytodetritus to the deep-sea floor. Proc R Soc Edinb 88B:265-279

Richardson MJ, Hollister CD (1987) Compositional changes in particulate matter on the Iceland Rise, through the water column, and at the seafloor. J Mar Res 45:175-200

Riebesell U (1989) Comparison of sinking and sedimentation rate measurements in a diatom winter/spring bloom. Mar Ecol Prog Ser 54:109-119

Riebesell U (1991a) Particle aggregation during a diatom bloom. I. Physical aspects. Mar Ecol Prog Ser 69:273-280

Riebesell U (1991b) Particle aggregation during a diatom bloom. II. Biological aspects. Mar Ecol Prog Ser 69: 281-291

Riebesell U (1992) The formation of large marine snow and its sustained residence in surface waters. Limnol Oceanogr $37: 63-76$

Riebesell U (1993) Aggregation of Phaeocystis during phytoplankton spring blooms in the southern North Sea. Mar Ecol Prog Ser 96:281-289

Riebesell U, Wolf-Gladrow DA (1992) The relationship between physical aggregation of phytoplankton and particle flux: a numerical model. Deep-Sea Res 39:1085-1102

Riebesell U, Schloss I, Smetacek V (1991) Aggregation of algae released from melting sea ice: implications for seeding and sedimentation. Polar Biol 11:239-248

Riebesell U, Reigstad M, Wassmann P, Noji T, Passow U (1995) On the trophic fate of Phaeocystis pouchetii (Hariot): VI. Significance of Phaeocystis-derived mucus for vertical flux. Neth J Sea Res 33:193-203

Riemann F (1989) Gelatinous phytoplankton detritus aggregates on the Atlantic deep-sea bed: structure and mode of formation. Mar Biol 100:533-539

Riley GA (1963) Organic aggregates in seawater and the dynamics of their formation and utilization. Limnol Oceanogr 8:372-381

Riley GA (1970) Particulate matter in seawater. Adv Mar Biol 8:1-118

Rivkin RB, Legendre L, Deibel D, Tremblay JE and 15 others (1996) Vertical flux of biogenic carbon in the ocean: is there food web control? Science 272:1163-1166

Rixen T, Haake B, Ittekkot V (2000) Sedimentation in the western Arabian Sea: the role of coastal and open-ocean upwelling. Deep-Sea Res II 47:2155-2178

Robbins EI, Porter KG, Haberyan KA (1985) Pellet microfossils: possible evidence for metazoan life in Early Proterozoic time. Proc Natl Acad Sci USA 82:5809-5813

Robertson DR (1982) Fish feces as fish food on a Pacific coral reef. Mar Ecol Prog Ser 7:253-265

Robison BH, Bailey TG (1981) Sinking rates and dissolution of midwater fish fecal matter. Mar Biol 65:135-142

Rodier M, Le Borgne R (1997) Export flux of particles at the equator in the western and central Pacific Ocean. DeepSea Res II 44:2085-2113

Roman MR, Gauzens AL (1997) Copepod grazing in the equatorial Pacific. Limnol Oceanogr 42:623-634

Romero N, Silverberg N, Roy S, Lovejoy C (2000) Sediment trap observations from the Gulf of St. Lawrence and the continental margin of eastern Canada. Deep-Sea Res II 47: 545-583

Romero OE, Fischer G, Lange CB, Wefer G (2000) Siliceous phytoplankton of the western equatorial Atlantic: sediment traps and surface sediments. Deep-Sea Res II 47: 1939-1959

Romero OE, Hebbeln D, Wefer G (2001) Temporal and spatial variability in export production in the SE Pacific Ocean: evidence from siliceous plankton fluxes and surface sediment assemblages. Deep-Sea Res I 48:2673-2697

Rowe GT, Gardner WD (1979) Sedimentation rates in the slope water of the northwest Atlantic Ocean measured directly with sediment traps. J Mar Res 37:581-600

Rowe GT, Sibuet M, Deming J, Tietjen J, Khripounoff A (1990) Organic carbon turnover time in deep-sea benthos. Prog Oceanogr 24:141-160

Rowe GT, Boland GS, Phoel WC, Anderson RF, Biscaye PE (1994) Deep-sea floor respiration as an indication of lateral input of biogenic detritus from continental margins. DeepSea Res II 41:657-668

Roy S, Poulet SA (1990) Laboratory study of the chemical composition of aging copepod fecal material. J Exp Mar Biol Ecol 135:3-18

Roy S, Silverberg N, Romero N, Deibel D, and 6 others (2000) Importance of mesozooplankton feeding for the downward flux of biogenic carbon in the Gulf of St. Lawrence (Canada). Deep-Sea Res II 47:519-544

Rudnick DT (1989) Time lags between the deposition and meiobenthic assimilation of phytodetritus. Mar Ecol Prog Ser 50:231-240

Rutgers van der Loeff MM, Berger GW (1991) Scavenging and particle flux: seasonal and regional variations in the Southern Ocean (Atlantic sector). Mar Chem 35:553-567

Sakugawa H, Handa N, Yagi K (1990) Distribution of glycosylglycerols and oligosaccharides in the marine environment and their ecological significance in the deep sea. Mar Biol 106:309-313

Sancetta C (1989a) Spatial and temporal trends of diatom flux in British Columbian fjords. J Plankton Res 11:503-520

Sancetta C (1989b) Sediment transport by fecal pellets in British Columbian fjords. Mar Geol 89:331-346

Sancetta C (1993) Green sea, black mud. Nature 362:108

Sancetta C (1999) The mystery of the sapropels. Nature 398: $27-29$

Sancetta C, Calvert SE (1988) The annual cycle of sedimentation in Saanich Inlet, British Columbia: implications for the interpretation of diatom fossil assemblages. Deep-Sea Res 35:71-90

Sancetta C, Villareal T, Falkowski P (1992) Massive fluxes of rhizosolenoid diatoms: a common occurrence? Limnol Oceanogr 36:1452-1457

Sapozhnikov VV, Pasternak AF (1988) Decomposition of fecal pellets during simulated sinking. Oceanology 28:244-248

Sarmiento JL (1991) Oceanic uptake of anthropogenic $\mathrm{CO}_{2}$ : the major uncertainties. Global Biogeochem Cycles 5: 309-313

Sasaki H, Nishizawa S (1981) Vertical flux profiles of particulate material in the sea off Sanriku. Mar Ecol Prog Ser 6: 191-201

Sasaki H, Hattori H, Nishizawa S (1988) Downward flux of particulate organic matter and vertical distribution of calanoid copepods in the Oyashio Water in summer. DeepSea Res 35:505-515

Sautter LR, Thunell RC (1991) Planktonic foraminiferal response to upwelling and seasonal hydrographic conditions: sediment trap results from San Pedro Basin, South- 
ern California Bight. J Foraminiferal Res 21:347-363

Sayles FL, Martin WR, Deuser WG (1994) Response of benthic oxygen demand to particulate organic carbon supply in the deep sea near Bermuda. Nature 371:686-689

Scharek R, Tupas LM, Karl DM (1999) Diatom fluxes to the deep sea in the oligotrophic North Pacific gyre at Station ALOHA. Mar Ecol Prog Ser 182:55-67

Scheidegger KF, Krissek LA (1983) Zooplankton and nekton: natural barriers to the seaward transport of suspended terrigenous particles off Peru. In: Suess E, Thiede J (eds) Coastal upwelling: its sediment record. Part A. Responses of the sedimentary regime to present coastal upwelling. Plenum, New York, p 303-333

Schnack SB (1985) A note on sedimentation of particulate matter in Antarctic waters during summer. Meeresforschung 30:306-315

Scholten JC, Fietzke J, Vogler S, Rutgers van der Loeff MM and 7 others (2001) Trapping efficiencies of sediment traps from the deep Eastern North Atlantic: the ${ }^{230}$ Th calibration. Deep-Sea Res II 48:2383-2408

Schrader HJ (1971) Fecal pellets: role in sedimentation of pelagic diatoms. Science 174:55-57

Schubert CJ, Villanueva J, Calvert SE, Cowie GL and 4 others (1998) Stable phytoplankton community structure in the Arabian Sea over the past 200,000 years. Nature 394: 563-566

Schuster S, Herndl GJ (1995) Formation and significance of transparent exopolymeric particles in the northern Adriatic Sea. Mar Ecol Prog Ser 124:227-236

Sempéré R, Yoro SC, Van Wambeke F, Charrière B (2000) Microbial decomposition of large organic particles in the northwestern Mediterranean Sea: an experimental approach. Mar Ecol Prog Ser 198:61-72

Shanks AL, del Carmen KA (1997) Larval polychaetes are strongly associated with marine snow. Mar Ecol Prog Ser 154:211-221

Shanks AL, Edmonson EW (1990) The vertical flux of metazoans (holoplankton, meiofauna, and larval invertebrates) due to their association with marine snow. Limnol Oceanogr 35:455-463

Shanks AL, Trent JD (1980) Marine snow: sinking rates and potential role in vertical flux. Deep-Sea Res 27:137-144

Shanks AL, Walters K (1997) Holoplankton, meroplankton, and meiofauna associated with marine snow. Mar Ecol Prog Ser 158:75-86

Shaw TJ, Smoak JM, Lauerman L (1998) Scavenging of ${ }^{234} \mathrm{Th}$, ${ }^{230} \mathrm{Th}$, and ${ }^{210} \mathrm{~Pb}$ by particulate matter in the water column of the California Continental Margin. Deep-Sea Res II 45: 763-779

Sheldon RW, Evelyn TP, Parsons TR (1967) On the occurrence and formation of small particles in seawater. Limnol Oceanogr 12:367-375

Sherrell RM, Field MP, Gao Y (1998) Temporal variability of suspended mass and composition in the Northeast Pacific water column: relationships to sinking flux and lateral advection. Deep-Sea Res II 45:733-761

Shimeta J (1993) Diffusional encounter of submicrometer particles and small cells by suspension feeders. Limnol Oceanogr 38:456-465

Silver MW, Alldredge AL (1981) Bathypelagic marine snow: deep-sea algal and detrital community. J Mar Res 39: 501-530

Silver MW, Bruland KW (1981) Differential feeding and fecal pellet composition of salps and pteropods, and the possible origin of the deep-water flora and olive-green 'cells.' Mar Biol 62:263-273

Silver MW, Gowing MM (1991) The 'particle' flux: origins and biological components. Prog Oceanogr 26:75-113

Silver MW, Shanks AL, Trent JD (1978) Marine snow: microplankton habitat and source of small-scale patchiness in pelagic populations. Science 201:371-373

Silver MW, Gowing MM, Brownlee DC, Corliss JO (1984) Ciliated protozoa associated with oceanic sinking detritus. Nature 309:246-248

Silver MW, Gowing MM, Davoll PJ (1986) The association of photosynthetic picoplankton and ultraplankton with pelagic detritus through the water column $(0-220 \mathrm{~m})$. Can Bull Fish Aquat Sci 214:311-341

Silver MW, Coale SL, Pilskaln CH, Steinberg DR (1998a) Giant aggregates: importance as microbial centers and agents of material flux in the mesopelagic zone. Limnol Oceanogr 43:498-507

Silver MW, Coale SL, Pilskaln CH, Chavez FP (1998b) Exploratory observations of marine aggregates at subeuphotic depths. Deep-Sea Res II 45:1839-1861

Simon M, Alldredge AL, Azam F (1990) Bacterial carbon dynamics on marine snow. Mar Ecol Prog Ser 65:205-211

Simon M, Welschmeyer NA, Kirchman DL (1992) Bacterial production and the sinking flux of particulate organic matter in the subarctic Pacific. Deep-Sea Res 39:1997-2008

Simoneit BRT, Grimalt JO, Fischer K, Dymond J (1986) Upward and downward flux of particulate organic material in abyssal waters of the Pacific Ocean. Naturwissenschaften 73:322-325

Skjoldal HR, Wassmann P (1986) Sedimentation of particulate organic matter and silicium during spring and summer in Lindåspollene, western Norway. Mar Ecol Prog Ser 30: $49-63$

Sleeter TD, Butler JN (1982) Petroleum hydrocarbons in zooplankton faecal pellets from the Sargasso Sea. Mar Pollut Bull 13:54-56

Small LF, Ellis SG (1992) Fecal carbon production by zooplankton in Santa Monica Basin: the effects of body size and carnivorous feeding. Prog Oceanogr 30:197-221

Small LF, Fowler SW, Ünlü MY (1979) Sinking rates of natural copepod fecal pellets. Mar Biol 51:233-241

Small LF, Fowler SW, Moore SA, La Rosa J (1983) Dissolved and fecal pellet carbon and nitrogen release by zooplankton in tropical waters. Deep-Sea Res 30:1199-1220

Small LF, Knauer GA, Tuel MD (1987) The role of sinking fecal pellets in stratified euphotic zones. Deep-Sea Res 34: $1705-1712$

Small LF, Landry MR, Eppley RW, Azam F, Carlucci AF (1989) Role of plankton in the carbon and nitrogen budgets of Santa Monica Basin, California. Mar Ecol Prog Ser 56: $57-74$

Smayda TJ (1970) The sinking and suspension of phytoplankton in the sea. Oceanogr Mar Biol Annu Rev 8:353-414

Smayda TJ (1971) Normal and accelerated sinking of phytoplankton in the sea. Mar Geol 11:105-122

Smayda TJ, Bienfang PK (1983) Suspension properties of various phyletic groups of phytoplankton and tintinnids in an oligotrophic, subtropical system. PSZN I: Mar Ecol 4: 289-300

Smetacek V (1980a) Zooplankton standing stock, copepod faecal pellets and particulate detritus in Kiel Bight. Est Coast Mar Sci 11:477-490

Smetacek V (1980b) Annual cycle of sedimentation in relation to plankton ecology in western Kiel Bight. Ophelia (Suppl) 1:65-76

Smetacek V (1984) The supply of food to the benthos. In: Fasham MJR (ed) Flows of energy and materials in marine ecosystems: theory and practice. Plenum Press, New York, p 517-547 
Smetacek V (1985) Role of sinking in diatom life-history cycles: ecological, evolutionary and geological significance. Mar Biol 84:239-251

Smetacek V (2000) The giant diatom dump. Nature 406: 574-575

Smetacek V, Hendrikson P (1979) Composition of particulate organic matter in Kiel Bight in relation to phytoplankton succession. Oceanol Acta 2:287-298

Smetacek V, von Bröckel K, Zeitzschel B, Zenk W (1978) Sedimentation of particulate matter during a phytoplankton spring bloom in relation to the hydrographical regime. Mar Biol 47:211-226

Smetacek V, von Bodungen B, Knoppers B, Peinert R and 3 others (1984) Seasonal stages describing the annual cycle of an inshore pelagic system. Rapp P-V Réun Cons Int Explor Mer 183:126-135

Smith CR, Hoover DJ, Doan SE, Pope RH and 3 others (1996) Phytodetritus at the abyssal seafloor across $10^{\circ}$ of latitude in the central equatorial Pacific. Deep-Sea Res II 43: 1309-1338

Smith DC, Simon M, Alldredge AL, Azam F (1992) Intense hydrolytic enzyme activity on marine aggregates and implications for rapid particle dissolution. Nature 359: 139-142

Smith KL Jr (1987) Food energy supply and demand: a discrepancy between particulate organic carbon flux and sediment community oxygen consumption in the deep ocean. Limnol Oceanogr 32:201-220

Smith KL Jr (1989) Short time-series measurements of particulate organic carbon flux and sediment community oxygen consumption in the North Pacific. Deep-Sea Res 36: 1111-1119

Smith KL Jr, Baldwin RJ (1984) Seasonal fluctuations in deepsea sediment community oxygen consumption: central and eastern North Pacific. Nature 307:624-625

Smith KL Jr, Druffel ERM (1998) Long time-series monitoring of an abyssal site in the NE Pacific: an introduction. DeepSea Res II 45:573-586

Smith KL Jr, Kaufmann RS (1999) Long-term discrepancy between food supply and demand in the deep eastern North Pacific. Science 284:1174-1177

Smith KL Jr, Carlucci AF, Jahnke RA, Craven DB (1987) Organic carbon mineralization in the Santa Catalina Basin: benthic boundary layer metabolism. Deep-Sea Res 34:185-211

Smith KL Jr, Baldwin RJ, Edelman JL (1989a) Supply of and demand for organic matter by sediment communities on two central North Pacific seamounts. Deep-Sea Res 36: 1917-1932

Smith KL Jr, Williams PM, Druffel ERM (1989b) Upward fluxes of particulate organic matter in the deep North Pacific. Nature 337:724-726

Smith KL Jr, Baldwin RJ, Williams PM (1992) Reconciling particulate organic carbon flux and sediment community oxygen consumption in the deep North Pacific. Nature 359: 313-316

Smith KL Jr, Kaufmann RS, Baldwin RJ (1994) Coupling of near-bottom pelagic and benthic processes at abyssal depths in the eastern North Pacific Ocean. Limnol Oceanogr 39:1101-1118

Smith KL Jr, Baldwin RJ, Glatts RC, Kaufmann RS, Fisher EC (1998) Detrital aggregates on the sea floor: chemical composition and aerobic decomposition rates at a time-series station in the abyssal NE Pacific. Deep-Sea Res II 45: 843-880

Smith KL Jr, Kaufmann RS, Baldwin RJ, Carlucci AF (2001) Pelagic-benthic coupling in the abyssal eastern North
Pacific: an 8-year time-series study of food supply and demand. Limnol Oceanogr 46:543-556

Smith SL (2001) Understanding the Arabian Sea: reflections on the 1994-1996 Arabian Sea Expedition. Deep-Sea Res II 48:1385-1402

Sochard MR, Wilson DF, Austin B, Colwell RR (1979) Bacteria associated with the surface and gut of marine copepods. Appl Environ Microbiol 37:750-759

Soutar A, Kling SA, Crill PA, Duffrin E, Bruland KW (1977) Monitoring the marine environment through sedimentation. Nature 266:136-139

Spencer DW, Honjo S, Brewer PG (1978a) Particles and particle fluxes in the ocean. Oceanus 21:20-25

Spencer DW, Brewer PG, Fleer A, Honjo S, Krishnaswami S, Nozaki Y (1978b) Chemical fluxes from sediment traps in the deep Sargasso Sea. J Mar Res 36:493-523

Stachowitsch M, Fanuko N, Richter M (1990) Mucus aggregates in the Adriatic Sea: an overview of stages and occurrences. PSZN I: Mar Ecol 11:327-350

Staresinic N, von Bröckel K, Smodlaka N, Clifford CH (1982) A comparison of moored and free-drifting sediment traps of two different designs. J Mar Res 40:273-292

Staresinic N, Farrington J, Gagosian RB, Clifford CH, Hulburt EM (1983) Downward transport of particulate matter in the Peru coastal upwelling: role of the anchoveta, Engraulis ringens. In: Suess E, Thiede J (eds) Coastal upwelling: its sediment record. Part A. Responses of the sedimentary regime to present coastal upwelling. Plenum, New York, p 225-240

Stavrakakis S, Chronis G, Tselepides A, Heussner S, Monaco A, Abassi A (2000) Downward fluxes of settling particles in the deep Cretan Sea (NE Mediterranean). Prog Oceanogr 46:217-240

Steele JH, Baird IE (1972) Sedimentation of organic matter in a Scottish sea loch. Mem Ist Ital Idrobiol 29(Suppl):73-88

Steinberg DK, Silver MW, Pilskaln CH, Coale SL, Paduan JB (1994) Midwater zooplankton communities on pelagic detritus (giant larvacean houses) in Monterey Bay, California. Limnol Oceanogr 39:1606-1620

Steinberg DK, Silver MW, Pilskaln CH (1997) Role of mesopelagic zooplankton in the community metabolism of giant larvacean house detritus in Monterey Bay, California, USA. Mar Ecol Prog Ser 147:167-179

Steinberg DK, Pilskaln CH, Silver MW (1998) Contribution of zooplankton associated with detritus to sediment trap 'swimmer' carbon in Monterey Bay, California, USA. Mar Ecol Prog Ser 164:157-166

Steinberg DK, Carlson CA, Bates NR, Goldthwait SA, Madin LP, Michaels AF (2000) Zooplankton vertical migration and the active transport of dissolved organic and inorganic carbon in the Sargasso Sea. Deep-Sea Res I 47: $137-158$

Steinberg DK, Carlson CA, Bates NR, Johnson RJ, Michaels AF, Knap AH (2001) Overview of the US JGOFS Bermuda Atlantic Time-series Study (BATS): a decade-scale look at ocean biology and biogeochemistry. Deep-Sea Res II 48: 1405-1447

Stoecker DK (1984) Particle production by planktonic ciliates. Limnol Oceanogr 29:930-940

Stolzenbach KD (1993) Scavenging of small particles by fastsinking porous aggregates. Deep-Sea Res I 40:359-369

Stolzenbach KD, Elimelech M (1994) The effect of particle density on collisions between sinking particles-implications for particle aggregation in the ocean. Deep-Sea Res I 41:469-483

Sumida PTG, Tyler PA, Lampitt RS, Gage JD (2000) Reproduction, dispersal and settlement of the bathyal ophiuroid 
Ophiocten gracilis in the NE Atlantic Ocean. Mar Biol 137: 623-630

Sutcliffe WH, Baylor ER, Menzel DW (1963) Sea surface chemistry and Langmuir circulation. Deep-Sea Res 10: $233-243$

Suzuki N, Kato K (1953) Studies on suspended materials: marine snow in the sea. I. Sources of marine snow. Bull Fac Fish Hokkaido Univ 4:132-135

Svensen C, Nejstgaard JC (2001) Sedimentation of copepod faecal pellets determined by calanoid-cyclopoid interactions? Evidence from enclosed ecosystems. Abstracts of papers presented at the American Society of Limnology and Oceanography Meeting, Albuquerque, New Mexico, February 12 to 16,2001 , p 137

Svensen C, Egge JK, Stiansen JE (2001) Can silicate and turbulence regulate the vertical flux of biogenic matter? A mesocosm study. Mar Ecol Prog Ser 217:67-80

Syvitski JPM, Murray JW (1981) Particle interaction in fjord suspended sediment. Mar Geol 39:215-242

Taghon GL, Nowell ARM, Jumars PA (1984) Transport and breakdown of fecal pellets: biological and sedimentological consequences. Limnol Oceanogr 29:64-72

Taguchi S (1982a) Sedimentation of newly produced particulate organic matter in a subtropical inlet, Kaneohe Bay, Hawaii. Est Coast Shelf Sci 14:533-544

Taguchi S (1982b) Seasonal study of fecal pellets and discarded houses of appendicularia in a subtropical inlet, Kaneohe Bay, Hawaii. Est Coast Shelf Sci 14:545-555

Taguchi S, Hargrave BT (1978) Loss rates of suspended material sedimented in a marine bay. J Fish Res Board Can 35: $1614-1620$

Takahashi K (1986) Seasonal fluxes of pelagic diatoms in the subarctic Pacific, 1982-1983. Deep-Sea Res 33:1225-1251

Takahashi K (1987a) Seasonal fluxes of silicoflagellates and Actiniscus in the subarctic Pacific during 1982-1984. J Mar Res 45:397-425

Takahashi K (1987b) Response of subarctic Pacific diatom fluxes to the 1982-1983 El Niño disturbance. J Geophys Res 92:14387-14392

Takahashi K (1987c) Radiolarian flux and seasonality: climatic and El Niño response in the subarctic Pacific, 1982-1984. Global Biogeochem Cycles 1:213-231

Takahashi K (1989) Silicoflagellates as productivity indicators: evidence from long temporal and spatial flux variability responding to hydrography in the northeastern Pacific. Global Biogeochem Cycles 3:43-61

Takahashi K, Honjo S (1981) Vertical flux of sedimentary radiolaria: a taxonomic approach of sediment trap study from the western tropical Atlantic. Micropaleontology 22: $140-190$

Takahashi K, Billings JD, Morgan JK (1990) Oceanic province: assessment from the time-series diatom fluxes in the northeastern Pacific. Limnol Oceanogr 35:154-165

Tambiev SB (1987) New data on the constituents and chemical composition of the suspended and freely sinking particulate matter in the Black Sea waters. Mitt Geol-Paläontol Inst Univ Hamburg 62:41-54

Tang KW (2001) Defecation of dimethylsulfoniopropionate (DMSP) by the copepod Acartia tonsa as functions of ambient food concentration and body DMSP content. J Plankton Res 23:549-553

Tanoue E (1985a) Organic chemical composition of fecal pellet of the krill Euphausia superba Dana. I. Lipid composition. Trans Tokyo Univ Fish 6:125-134

Tanoue E (1985b) Organic chemical composition of fecal pellet of the krill Euphausia superba Dana. II. Amino acid composition. Trans Tokyo Univ Fish 6:135-138
Tanoue E, Handa N (1980) Vertical transport of organic materials in the northern North Pacific as determined by sediment trap experiment. Part 1. Fatty acid composition. J Oceanogr Soc Jpn 36:231-245

Tanoue E, Handa N (1987) Monosaccharide composition of marine particles and sediments from the Bering Sea and northern North Pacific. Oceanol Acta 10:91-99

Tanoue E, Hara S (1986) Ecological implications of fecal pellets produced by the Antarctic krill Euphausia superba in the Antarctic Ocean. Mar Biol 91:359-369

Tanoue E, Handa N, Sakugawa H (1982) Difference of the chemical composition of organic matter between fecal pellet of Euphausia superba and its feed, Dunaliella tertiolecta. Trans Tokyo Univ Fish 5:189-196

Taylor GT (1989) Variability in the vertical flux of microorganisms and biogenic material in the epipelagic zone of a North Pacific central gyre station. Deep-Sea Res 36: $1287-1308$

Taylor GT, Karl DM (1991) Vertical fluxes of biogenic particles and associated biota in the eastern north Pacific: implications for biogeochemical cycling and productivity. Global Biogeochem Cycles 5:289-303

Taylor GT, Karl DM, Pace ML (1986) Impact of bacteria and zooflagellates on the composition of sinking particles: an in situ experiment. Mar Ecol Prog Ser 29:141-155

Tett $\mathrm{P}$ (1984) Fixation of $\mathrm{CO}_{2}$ in dark midwater zones of the ocean. Nature 309:14

Thibault D, Roy S, Wong CS, Bishop JK (1999) The downward flux of biogenic material in the NE subarctic Pacific: importance of algal sinking and mesozooplankton herbivory. Deep-Sea Res II 46:2669-2697

Thiel H, Pfannkuche O, Schriever G, Lochte K and 6 others (1988) Phytodetritus on the deep-sea floor in a central oceanic region of the North Atlantic. Biol Oceanogr 6: 203-239

Thingstad TF, Rassoulzadegan F (1995) Nutrient limitations, microbial food webs, and 'biological C-pumps': suggested interactions in a P-limited Mediterranean. Mar Ecol Prog Ser 117:299-306

Thomson CW (1873) The depths of the sea. Macmillan, London

Thunell RC (1997) Continental margin particle flux. Oceanus 40:20-23

Thunell RC (1998a) Seasonal and annual variability in particle fluxes in the Gulf of California: a response to climate forcing. Deep-Sea Res I 45:2059-2083

Thunell RC (1998b) Particle fluxes in a coastal upwelling zone: sediment trap results from Santa Barbara Basin, California. Deep-Sea Res II 45:1863-1884

Thunell RC, Honjo S (1981) Planktonic foraminiferal flux to the deep ocean: sediment trap results from the tropical Atlantic and the central Pacific. Mar Geol 40:237-253

Thunell RC, Moore WS, Dymond J, Pilskaln CH (1994a) Elemental and isotopic fluxes in the Southern California Bight: a time-series sediment trap study in the San Pedro Basin. J Geophys Res 99:875-889

Thunell RC, Pilskaln CH, Tappa E, Sautter LR (1994b) Temporal variability in sediment fluxes in the San Pedro Basin, Southern California Bight. Cont Shelf Res 14:333-352

Thunell RC, Varela R, Llano M, Collister J, Muller-Karger F, Bohrer R (2000) Organic carbon fluxes, degradation, and accumulation in an anoxic basin: sediment trap results from the Cariaco Basin. Limnol Oceanogr 45:300-308

Tiselius P, Kiørboe T (1998) Colonization of diatom aggregates by the dinoflagellate Noctiluca scintillans. Limnol Oceanogr 43:154-159

Toggweiler JR (1989) Is the downward dissolved organic 
matter (DOM) flux important in carbon transport? In: Berger WH, Smetacek VS, Wefer G (eds) Productivity of the ocean: present and past. John Wiley \& Sons, Chichester, $\mathrm{p}$ 65-83

Tranvik CJ, Sherr EB, Sherr BF (1993) Uptake and utilization of 'colloidal DOM' by heterotrophic flagellates in seawater. Mar Ecol Prog Ser 92:301-309

Tremblay C, Runge JA, Legendre L (1989) Grazing and sedimentation of ice algae during and immediately after a bloom at the ice-water interface. Mar Ecol Prog Ser 56: 291-300

Trent JD, Shanks AL, Silver MW (1978) In situ and laboratory measurements on macroscopic aggregates in Monterey Bay, California. Limnol Oceanogr 23:626-635

Trimmer M, Gowen RJ, Stewart BM, Nedwell DB (1999) The spring bloom and its impact on benthic mineralisation rates in western Irish Sea sediments. Mar Ecol Prog Ser 185:37-46

Trull TW, Armand L (2001) Insights into Southern Ocean carbon export from the $\delta^{13} \mathrm{C}$ of particles and dissolved inorganic carbon during the SOIREE iron release experiment. Deep-Sea Res II 48:2655-2680

Tsuda A, Nemoto T (1990) The effect of food concentration on the faecal pellet size of the marine copepod Pseudocalanus newmani Frost. Bull Plankton Soc Jpn 37:83-90

Tsujita T (1952) A preliminary study on naturally occurring suspended organic matter in water adjacent to Japan. J Oceanogr Soc Jpn 8:3-4

Tsunogai S, Noriki S (1987) Organic matter fluxes and the sites of oxygen consumption in deep water. Deep-Sea Res 34:755-767

Tsunogai S, Noriki S (1991) Particulate fluxes of carbonate and organic carbon in the ocean. Is the marine biological activity working as a sink of the atmospheric carbon? Tellus 43B:256-266

Tsunogai S, Taguchi K, Harada K (1986a) Seasonal variation in the difference between observed and calculated particulate fluxes of Th-234 in Funka Bay, Japan. J Oceanogr Soc Jpn 42:91-96

Tsunogai S, Noriki S, Harada K, Kurosaki T, Watanabe Y, Maedaa M (1986b) Large but variable particulate flux in the Antarctic Ocean and its significance for the chemistry of Antarctic water. J Oceanogr Soc Jpn 42:83-90

Turley CM (1991) Protozoa associated with marine 'snow' and 'fluff' — Session summary. In: Reid PC et al. (eds) Protozoa and their role in marine processes. NATO ASI Series, Vol G 25. Springer-Verlag, Berlin, p 309-326

Turley CM, Lochte K (1990) Microbial response to the input of fresh detritus to the deep-sea bed. Paleogeogr Palaeoclimatol Paleoecol 89:3-23

Turley CM, Mackie PJ (1994) Biogeochemical significance of attached and free-living bacteria and the flux of particles in the NE Atlantic Ocean. Mar Ecol Prog Ser 115:191-203

Turley CM, Mackie PJ (1995) Bacterial and cyanobacterial flux to the deep NE Atlantic on sedimenting particles. Deep-Sea Res I 42:1453-1474

Turner JT (1977) Sinking rates of fecal pellets from the marine copepod Pontella meadii. Mar Biol 40:249-259

Turner JT (1978) Scanning electron microscope investigations of feeding habits and mouthpart structures of three species of copepods of the Family Pontellidae. Bull Mar Sci 28:487-500

Turner JT (1979) Microbial attachment to copepod fecal pellets and its possible significance. Trans Am Microsc Soc 98:131-135

Turner JT (1984a) Zooplankton feeding ecology: contents of fecal pellets of the copepods Eucalanus pileatus and Para- calanus quasimodo from continental shelf waters of the Gulf of Mexico. Mar Ecol Prog Ser 15:27-46

Turner JT (1984b) Zooplankton feeding ecology: contents of fecal pellets of the copepods Acartia tonsa and Labidocera aestiva from continental shelf waters near the mouth of the Mississippi River. PSZN I: Mar Ecol 5:265-282

Turner JT (1984c) Zooplankton feeding ecology: contents of fecal pellets of the copepods Temora turbinata and $T$. stylifera from continental shelf and slope waters near the mouth of the Mississippi River. Mar Biol 82:73-83

Turner JT (1985) Zooplankton feeding ecology: contents of fecal pellets of the copepod Anomalocera ornata from continental shelf and slope waters of the Gulf of Mexico. PSZN I: Mar Ecol 6:285-298

Turner JT (1986a) Zooplankton feeding ecology: contents of fecal pellets of the copepod Undinula vulgaris from continental shelf waters of the Gulf of Mexico. PSZN I: Mar Ecol 7:1-14

Turner JT (1986b) Zooplankton feeding ecology: contents of fecal pellets of the cyclopoid copepods Oncaea venusta, Corycaeus amazonicus, Oithona plumifera and $O$. simplex from the northeastern Gulf of Mexico. PSZN I: Mar Ecol 7: 289-302

Turner JT (1987) Zooplankton feeding ecology: contents of fecal pellets of the copepod Centropages velificatus from waters near the mouth of the Mississippi River. Biol Bull 173:377-386

Turner JT (1991) Zooplankton feeding ecology: do co-occurring copepods compete for the same food? Rev Aquat Sci 5:101-195

Turner JT, Anderson DM (1983) Zooplankton grazing during dinoflagellate blooms in a Cape Cod embayment, with observations of predation upon tintinnids by copepods. PSZN I: Mar Ecol 4:359-374

Turner JT, Ferrante JG (1979) Zooplankton fecal pellets in aquatic ecosystems. BioScience 29:670-677

Tyler PA (1988) Seasonality in the deep sea. Oceanogr Mar Biol Annu Rev 26:227-258

Tyler PA, Grant A, Pain SL, Gage JD (1982) Is annual reproduction in deep-sea echinoderms a response to variability in their environment? Nature 300:747-750

Tyler PA, Billett DSM, Gage JD (1990) Seasonal reproduction in the seastar Dytaster grandis from $4000 \mathrm{~m}$ in the northeast Atlantic Ocean. J Mar Biol Assoc UK 70:173-180

Urban JL, McKenzie CH, Deibel D (1992) Seasonal differences in the content of Oikopleura vanhoeffenii and Calanus finmarchicus faecal pellets: illustrations of zooplankton food web shifts in coastal Newfoundland waters. Mar Ecol Prog Ser 84:255-264

Urban JL, Deibel D, Schwinghamer P (1993a) Seasonal variations in the densities of fecal pellets produced by Oikopelura vanhoeffeni (C. Larvacea) and Calanus finmarchicus (C. Copepoda). Mar Biol 117:607-613

Urban JL, McKenzie CH, Deibel D (1993b) Nanoplankton found in fecal pellets of macrozooplankton in coastal Newfoundland waters. Bot Mar 36:267-281

Urban-Rich J (1999) Release of dissolved organic carbon from copepod fecal pellets in the Greenland Sea. J Exp Mar Biol Ecol 232:107-124

Urban-Rich J (2001) The leaky pellet: what does it mean for carbon cycling? Abstracts of papers presented at the American Society of Limnology and Oceanography Meeting, Albuquerque, New Mexico, February 12 to 16, 2001, p 144

Urban-Rich J, Hansell DA, Roman MR (1998) Analysis of copepod fecal pellet carbon using a high temperature combustion method. Mar Ecol Prog Ser 171:199-208 
Urban-Rich J, Nordby E, Andreassen IJ, Wassmann P (1999) Contribution by mesozooplankton fecal pellets to the carbon flux on Nordvestbanken, north Norwegian shelf in 1994. Sarsia 84:253-264

Urrère MA, Knauer GA (1981) Zooplankton fecal pellet fluxes and vertical transport of particulate organic material in the pelagic environment. J Plankton Res 3:369-387

Uye SI, Kaname K (1994) Relations between fecal pellet volume and body size for major zooplankters of the Inland Sea of Japan. J Oceanogr 50:43-49

Valdes JR, Buesseler KO, Price JF (1997) A new way to catch the rain. Oceanus 40:33-35

Van der Wal P, Kempers RS, Veldhuis MJW (1995) Production and downward flux of organic matter and calcite in a North Sea bloom of the coccolithophore Emiliania huxleyi. Mar Ecol Prog Ser 126:247-265

Vangriesheim A, Khripounoff A (1990) Near-bottom particle concentration and flux: temporal variations observed with sediment traps and nephelometer on the Meriadzek Terrace, Bay of Biscay. Prog Oceanogr 24:103-116

Vernet M, Lorenzen CJ (1987) The presence of chlorophyll $b$ and the estimation of phaeopigments in marine phytoplankton. J Plankton Res 9:255-265

Viitasalo M, Rosenberg M, Heiskanen AS, Koski M (1999) Sedimentation of copepod fecal material in the coastal northern Baltic Sea: where did all the pellets go? Limnol Oceanogr 44:1388-1399

Vilicic D, Krsinic F, Bicanic Z (1994) The diatom Nitzschia sicula (Castr.) Hust. and naupliar faecal minipellets in the Adriatic Sea. PSZN I: Mar Ecol 15:27-39

Villareal TA, Altabet MA, Culver-Rymsza K (1993) Nitrogen transport by vertically migrating diatom mats in the North Pacific Ocean. Nature 363:709-712

Villareal TA, Woods S, Moore JK, Culver-Rymsza K (1996) Vertical migration of Rhizosolenia mats and their significance to $\mathrm{NO}_{3}{ }^{-}$fluxes in the central North Pacific gyre. J Plankton Res 18:1103-1121

Villareal TA, Pilskaln C, Bzrezinski M, Lipschultz F, Dennet M, Gardner GB (1999) Upward transport of oceanic nitrate by migrating diatom mats. Nature 397:423-433

Volkman JK, Corner EDS, Eglinton G (1980) Transformations of biolipids in the marine food web and in underlying bottom sediments. In: Colloques internationaux du CNRS No 293. Biogeochimie de la matiere organique a l'interface eau sediment marin. CNRS, Paris, p 185-197

Voss M (1991) Content of copepod faecal pellets in relation to food supply in Kiel Bight and its effect on sedimentation rate. Mar Ecol Prog Ser 75:217-225

Waite A, Bienfang PK, Harrison PJ (1992) Spring bloom sedimentation in a subarctic ecosystem. II. Succession and sedimentation. Mar Biol 114:131-138

Waite A, Gallager S, Dam HG (1997) New measurements of phytoplankton aggregation in a flocculator using videography and image analysis. Mar Ecol Prog Ser 155:77-88

Waite AM, Safi KA, Hall JA, Nodder SD (2000) Mass sedimentation of picoplankton embedded in organic aggregates. Limnol Oceanogr 45:87-97

Wakefield WW, Smith LK Jr (1990) Ontogenetic vertical migration in Sebastolobus altivelis as a mechanism for transport of particulate organic matter at continental slope depths. Limnol Oceanogr 35:1314-1328

Wakeham SG, Canuel EA (1986) Lipid composition of the pelagic crab Pleuroncodes planipes, its feces, and sinking particulate organic matter in the equatorial North Pacific Ocean. Org Geochem 9:331-343

Wakeham SG, Lee C (1989) Organic geochemistry of particulate matter in the ocean: the role of particles in oceanic sedimentary cycles. Org Geochem 14:83-96

Wakeham SG, Farrington JW, Gagosian RB, Lee C and 5 others (1980) Organic matter fluxes from sediment traps in the equatorial Atlantic Ocean. Nature 286:998-800

Wakeham SG, Lee C, Farrington JW, Gagosian RB (1984) Biogeochemistry of particulate organic matter in the oceans: results from sediment trap experiments. Deep-Sea Res 31: 509-528

Wakeham SG, Hedges JI, Lee C, Pease TK (1993) Effects of poisons and preservatives on the composition of organic matter in a sediment trap experiment. J Mar Res 51: 669-696

Wakeham SG, Hedges JI, Lee C, Peterson ML, Hernes PJ (1997) Compositions and transport of lipid biomarkers through the water column and surficial sediments of the equatorial Pacific Ocean. Deep-Sea Res II 44:2131-2162

Walsh I, Dymond J, Collier R (1988a) Rates of recycling of biogenic components of settling particles in the ocean derived from sediment trap experiments. Deep-Sea Res 35:43-58

Walsh I, Fischer K, Murray D, Dymond J (1988b) Evidence for resuspension of rebound particles from near-bottom sediment traps. Deep-Sea Res 35:59-70

Walsh JJ (1981) A carbon budget for overfishing off Peru. Nature 290:300-304

Walsh JJ (1983) Death in the sea: enigmatic phytoplankton losses. Prog Oceanogr 12:1-86

Walsh JJ (1994) Particle export at Cape Hatteras. Deep-Sea Res II 41:603-628

Walter M (1995) Faecal pellets in world events. Nature 376: $16-17$

Walters K, Shanks AL (1996) Complex trophic and nontrophic interactions between meiobenthic copepods and marine snow. J Exp Mar Biol Ecol 198:131-145

Wangersky PJ (1974) Particulate organic carbon: sampling variability. Limnol Oceanogr 19:980-984

Waniek J, Koeve W, Prien RD (2000) Trajectories of sinking particles and the catchment areas above sediment traps in the northeast Atlantic. J Mar Res 58:983-1006

Wassmann P (1983) Sedimentation of organic and inorganic particulate material in Lindåspollene, a stratified, landlocked fjord in western Norway. Mar Ecol Prog Ser 13: 237-248

Wassmann P (1984) Sedimentation and benthic mineralization of organic detritus in a Norwegian fjord. Mar Biol 83: 83-94

Wassmann P (1985) Sedimentation of particulate material in Nordåsvannet, a hypertrophic, land-locked fjord in western Norway. Mar Ecol Prog Ser 22:259-271

Wassmann P (1986) Benthic nutrient regeneration as related to primary productivity in the west-Norwegian coastal zone. Ophelia 26:443-456

Wassmann P (1989) Sedimentation of organic matter and silicate from the euphotic zone of the Barents Sea. Rapp P-V Réun Cons Int Explor Mer 188:108-114

Wassmann P (1990a) Relationship between primary and export production in the boreal coastal zone of the North Atlantic. Limnol Oceanogr 35:464-471

Wassmann P (1990b) Calculating the load of organic carbon to the aphotic zone in eutrophicated coastal waters. Mar Pollut Bull 21:183-187

Wassmann P (1991a) Dynamics of primary production and sedimentation in shallow fjords and polls of western Norway. Oceanogr Mar Biol Annu Rev 29:87-154

Wassmann P (1991b) Sampling and analysis of marine particles with PEBENOCO (Pelagic-Benthic Coupling in the Norwegian Coastal Zone), University of Tromsø, Norway. 
In: Marine particles: analysis and characterization. AGU Geophys Monogr 63:97-99

Wassmann P (1994) Significance of sedimentation for the termination of Phaeocystis blooms. J Mar Syst 5:81-100

Wassmann P (1998) Retention versus export food chains: processes controlling sinking loss from marine pelagic systems. Hydrobiologia 363:29-57

Wassmann P, Naas KE, Johannessen PJ (1986) Annual supply and loss of particulate organic carbon in Nordåsvannet, a eutrophic, land-locked fjord in western Norway. Rapp P-V Réun Cons Int Explor Mer 186:423-431

Wassmann P, Vernet M, Mitchell BG, Rey F (1990) Mass sedimentation of Phaeocystis pouchetii in the Barents Sea. Mar Ecol Prog Ser 66:183-195

Wassmann P, Peinert R, Smetacek V (1991) Patterns of production and sedimentation in the boreal and polar northeast Atlantic. In: Sakshaug E, Hopkins CCE, Øritsland NA (eds) Proceedings of the Pro Mare Symposium on Polar Marine Biology, Trondheim, 12 to 16 May 1990. Polar Res 10:209-228

Wassmann P, Martinez R, Vernet M (1994) Respiration and biochemical composition of sedimenting organic matter during summer in the Barents Sea. Cont Shelf Res 14:79-90

Wassmann P, Andreassen I, Reigstad M, Slagstad D (1996a) Pelagic-benthic coupling in the Nordic Seas: the role of episodic events. PSZN I: Mar Ecol 17:447-471

Wassmann P, Svendsen H, Keck A, Reigstad M (1996b) Selected aspects of the physical oceanography and particle fluxes in fjords of northern Norway. J Mar Syst 8:53-71

Wassmann P, Hansen L, Andreassen IJ, Riser CW, Urban-Rich J (1999) Distribution and sedimentation of faecal pellets on the Nordvestbanken shelf, northern Norway, in 1994. Sarsia 84:239-252

Wassmann P, Ypma JE, Tselepides A (2000) Vertical flux of faecal pellets and microplankton on the shelf of the oligotrophic Cretan Sea (NE Mediterranean Sea). Prog Oceanogr 46:241-258

Weeks A, Conte MH, Harris RP and 10 others (1993) The physical and chemical environment and changes in community structure associated with bloom evolution: the Joint Global Ocean Flux Study North Atlantic Bloom Experiment. Deep-Sea Res II 40:347-368

Wefer G (1989) Particle flux in the ocean: effects of episodic production. In: Berger WH, Smetacek VS, Wefer G (eds) Productivity of the ocean: present and past. John Wiley \& Sons, Chichester, p 139-153

Wefer G, Fischer G (1991) Annual primary production and export flux in the Southern Ocean from sediment trap data. Mar Chem 35:597-613

Wefer G, Suess E, Balzer W, Liebezeit A and 3 others (1982) Fluxes of biogenic components from sediment trap deployments in circumpolar waters of the Drake passage. Nature 299:145-147

Wefer G, Fischer G, Füetterer D, Gersonde R (1988) Seasonal particle flux in the Bransfield Strait, Antarctica. Deep-Sea Res 35:891-898

Wefer G, Fischer G, Füetterer D, Gersonde R, Honjo s, Ostermann D (1990) Particle sedimentation and productivity in Antarctic waters of the Atlantic sector. In: Bleil U, Thiede J (eds) Geological history of polar oceans: Arctic versus Antarctic. Kluwer Academic Publishers, Dordrecht, p 363-379

Welschmeyer NA, Lorenzen CJ (1985) Role of herbivory in controlling phytoplankton abundance: annual pigment budget for a temperate marine fjord. Mar Biol 90:75-86

Welschmeyer NA, Copping AE, Vernet M, Lorenzen CJ (1984) Diel fluctuation in zooplankton grazing rate as determined from the downward vertical flux of phaeopigments. Mar Biol 83:263-270

Wiebe PH, Boyd SH, Winget C (1976) Particulate matter sinking to the deep-sea floor at $2000 \mathrm{~m}$ in the Tongue of the Ocean, Bahamas, with a description of a new sedimentation trap. J Mar Res 34:341-354

Wiebe PH, Madin LP, Haury LR, Harbison GR, Philbin LM (1979) Diel vertical migration by Salpa aspera and its potential for large-scale particulate organic matter transport to the deep-sea. Mar Biol 53:249-255

Wiebe WJ, Pomeroy LR (1972) Microorganisms and their association with aggregates and detritus in the sea: a microscopic study. Mem Ist Ital Idrobiol 29(Suppl): 325-352

Williams PM, Druffel ERM, Smith KL Jr (1987) Dietary carbon sources for deep-sea organisms as inferred from their organic radiocarbon activities. Deep-Sea Res 34:253-266

Witte U (1996) Seasonal reproduction in deep-sea sponges: triggered by vertical particle flux? Mar Biol 124:571-581

Wollast R, Chou L (2001) The carbon cycle at the ocean margin in the northern Gulf of Biscay. Deep-Sea Res II 48: 3265-3293

Wong CS, Whitney FA, Crawford DW, Iseki K and 4 others (1999) Seasonal and interannual variability in particle fluxes of carbon, nitrogan and silicon from time series of sediment traps at Ocean Station P, 1982-1993: relationship to changes in subarctic primary productivity. DeepSea Res II 46:2735-2760

Wu J, Calvert SE, Wong CS, Whitney FA (1999) Carbon and nitrogen isotopic composition of sedimenting particulate material at Station Papa in the subarctic northeast Pacific. Deep-Sea Res II 46:2793-2832

Yoon WD, Marty JC, Sylvain D, Nival P (1996) Degradation of faecal pellets in Pegea confoederata (Salpidae, Thaliacea) and its implication in the vertical flux of organic matter. J Exp Mar Biol Ecol 203:147-177

Yoon WD, Kim SK, Han KN (2001) Morphology and sinking velocities of fecal pellets of copepod, molluscan, euphausiid, and salp taxa in the northeastern tropical Atlantic. Mar Biol 139:923-928

Young JR, Ziveri P (2000) Calculation of coccolith volume and its use in calibration of carbonate flux estimates. Deep-Sea Res II 47:1679-1700

Youngbluth MJ (1982) Utilization of a fecal mass as food by the pelagic mysis larva of the penaeid shrimp Solenocera atlantidis. Mar Biol 66:47-51

Youngbluth MJ, Bailey TG, Davoll PJ, Jacoby CA, BladesEckelbarger PI, Griswold CA (1989) Fecal pellet production and diel migratory behavior by the euphausiid Meganyctiphanes norvegica effect benthic-pelagic coupling. Deep-Sea Res 36:1491-1501

Zeldis J (2001) Mesozooplankton community composition, feeding, and export production during SOIREE. Deep-Sea Res II 48:2615-2634

Zhang X, Dam HG (1997) Downward export of carbon by diel migrant mesozooplankton in the central equatorial Pacific. Deep-Sea Res II 44:2191-2202

Ziveri P, Thunnel RC (2000) Coccolithophore export production in Guaymas Basin, Gulf of California: response to climate forcing. Deep-Sea Res II 47:2073-2100

Ziveri P, Broerse ATC, van Hinte JE, Westbroek P, Honjo S (2000) The fate of coccoliths at $48^{\circ} \mathrm{N} 21^{\circ} \mathrm{W}$, northeastern Atlantic. Deep-Sea Res II 47:1853-1875

Zonneveld KAF, Brummer GJA (2000) (Palaeo-)ecological significance, transport and preservation of organic-walled dinoflagellate cysts in the Somali Basin, NW Arabian Sea. Deep-Sea Res II 47:2229-2256 